\title{
PALEOBIOLOGY OF A NEOPROTEROZOIC TIDAL FLAT/LAGOONAL COMPLEX: THE DRAKEN CONGLOMERATE FORMATION, SPITSBERGEN
}

\author{
A. H. KNOLL, K. SWETT, AND J. MARK \\ Botanical Museum, Harvard University, Cambridge, Massachusetts 02138 , \\ Department of Geology, University of Iowa, Iowa City 52242, and \\ Department of Organismic and Evolutionary Biology, \\ Harvard University, Cambridge, Massachusetts 02138
}

\begin{abstract}
Carbonates and rare shales of the ca 700-800 Ma old Draken Conglomerate Formation, northeastern Spitsbergen, preserve a record of environmental variation within a Neoproterozoic tidal flat/lagoon complex. Forty-two microfossil taxa have been recognized in Draken rocks, and of these, 39 can be characterized in terms of their paleoenvironmental distributions along a gradient from the supratidal zone to permanently submerged lagoons. Supratidal to subtidal trends include: increasing microbenthic diversity, increasing abundance and diversity of included allochthonous (presumably planktonic) elements, decreasing sheath thickness of mat-building organisms (with significant taphonomic consequences), and an increasing sediment/fossil ratio in fossiliferous rocks. Five principal and several minor biofacies can be distinguished. The paleoecological resolution obtainable in the Draken Conglomerate Formation rivals that achieved for most Phanerozoic fossil deposits. It documents the complexity and diversity of Proterozoic coastal ecosystems and indicates that both environment and taphonomy need to be taken into explicit consideration in attempts to understand evolutionary trends in the early fossil record. Three species, Coniunctiophycus majorinum, Myxococcoides distola, and $M$. chlorelloidea, are described as new; Siphonophycus robustum, Siphonophycus septatum, and Gorgonisphaeridium maximum are proposed as new combinations.
\end{abstract}

\section{INTRODUCTION}

$I^{\mathrm{N}}$ N 1954 Tyler and Barghoorn reported well-preserved microfossils in cherts of the Paleoproterozoic Gunflint Iron Formation. Their discovery promised a paleontological understanding of life's early history, as well as micropaleontological tools for the stratigraphic correlation and paleoenvironmental interpretation of Archean and Proterozoic sedimentary rocks. The more general promise of Precambrian paleontology has been fulfilled. We now have confidence that life appeared early in our planet's development, that aerobic prokaryotes and mitochondria-bearing eukaryotes radiated much later, and that complex multicellularity in protists and animals evolved still later, in Meso- to Neoproterozoic times.

In contrast, the fuller promise of Tyler and Barghoorn's discovery-that Archean and Proterozoic microfossil taxa might be delimited in space and time, facilitating the kinds of contribution that paleontology has made to Phanerozoic stratigraphy and evolution-remains tantalizingly half fulfilled. Beginning with Timofeev (1959), palynologists have used acritarchs in the broad biostratigraphic subdivision of Neoproterozoic successions (e.g., Vidal, 1976; Jankauskas, 1982, 1989; Vidal and Knoll, 1983), while others have shown that certain microbenthic populations illuminate paleoenvironmental analysis (e.g., Golubic and Hofmann, 1976; Green et al., 1987, 1988). The Proterozoic is not the Phanerozoic, just as the Paleozoic is not the Pleistocene; but research completed during the past decade clearly indicates the potential for much finer stratigraphic, paleoenvironmental, and, hence, evolutionary resolution of the Proterozoic fossil record. Realization of this potential requires that microfossil distributions be brought into sharper focus through detailed systematic and paleoecological studies of well-preserved fossil assemblages within carefully measured stratigraphic sections.

The Neoproterozoic Draken Conglomerate Formation, Spitsbergen, provides an opportunity to test the limits of paleoecological resolution in Proterozoic micropaleontology. The preliminary work of Knoll (1982), based on Draken samples collected by the late Colin Wilson of the Cambridge Spitsbergen Expedition, showed that Draken cherts contain exceptionally well-preserved microfossil populations. Field expeditions to northeastern Spitsbergen in 1981, 1982, and 1986 have resulted in the documentation of $\mathbf{4 2}$ fossil-bearing horizons in cherts, carbonates, and shales collected from measured sections in three areas spanning a distance of just over $100 \mathrm{~km}$ along strike.

\section{GEOLOGICAL SETTING AND AGE}

The Neoproterozoic Lomfjorden Supergroup contains some $6,000 \mathrm{~m}$ of quartz arenite, shale, and carbonate exposed in nunataks throughout northeastern Spitsbergen (Figure 1; Wilson, 1961; Harland and Wright, 1979). Along with correlative beds in neighboring Nordaustlandet and central East Greenland, it documents deposition in a rapidly subsiding intracratonic basin that extended at least $650 \mathrm{~km}$ along strike. The lower two-thirds of this succession, the Veteranen Group, consist predominantly of cross-bedded and rippled quartz arenite with interbedded siltite, shale, and minor carbonate (Wilson, 1958; Knoll and Swett, 1985). In contrast, the overlying Akademikerbreen Group contains mostly carbonate, with only minor siliciclastic intercalations (Wilson, 1961; Knoll and Swett, 1990).

Akademikerbreen limestones and dolomites accumulated on a carbonate ramp. Constituent facies record depositional environments ranging from tidal flats through lagoons, oolitic shoals, and bioherms to offshore sites below fair weather wave base (Knoll and Swett, 1990). Although a marine setting is often difficult to demonstrate for Proterozoic rocks that lack skeletal fossils, several features strongly suggest that Akademikerbreen carbonates precipitated from sea water. The dimensions of the package $-650 \mathrm{~km}$ long and, especially, $2,000 \mathrm{~m}$ thick - are hard to reconcile with known lacustrine deposits. Sedimentary structures and facies relationships are those expected for marineplatform deposition, and there is no evidence of intercalated alluvial deposits. Carbon and strontium isotopic ratios in Akademikerbreen carbonates also suggest marine deposition (Knoll et al., 1986; Derry et al., 1989). Perhaps most important, some of the fossils described from Akademikerbreen rocks and their equivalents in East Greenland have close modern counterparts known only from marine environments (e.g., Green et al., 1987, 1988, 1989; Knoll et al., 1989). 

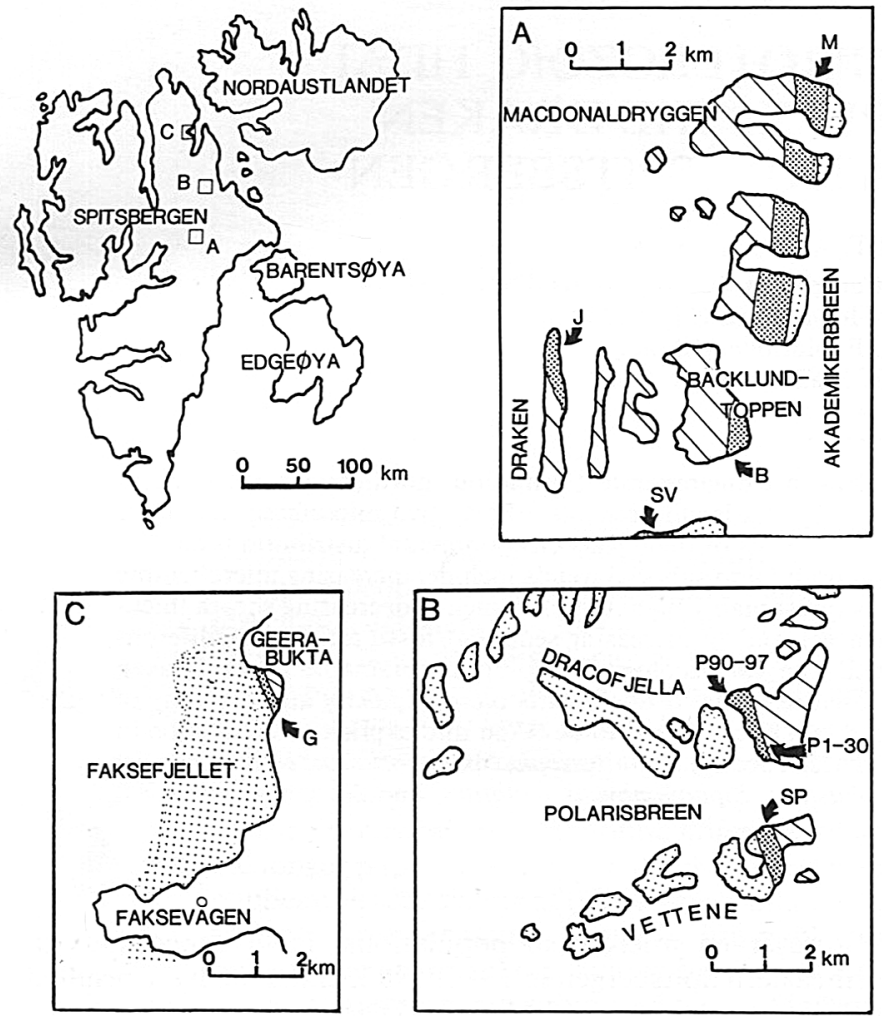

FIGURE 1-Map of Spitsbergen and neighboring islands, showing the locations of measured sections and samples (M, B, SV, J, G, SP, and $P)$ of the Draken Conglomerate Formation discussed in this paper. Densely stippled areas indicate Draken outcrop; lightly stippled areas represent pre-Draken successions; and diagonal stripes indicate postDraken rocks. White areas are ice covered.

The 150-250-m-thick Draken Conglomerate Formation begins just above the mid-point of the Akademikerbreen Group. It consists principally of $\mathrm{cm}$ - to dm-scale beds of intraclastic dolarenite to dolorudite, with interbedded dolomicrites (Figure 2). Oolites and oncolites are common, especially in the middle third of the formation. In the upper third, stratiform stromatolites, commonly associated with tepee structures, occur in intimate association with thin intraclastic dolomites and dolomicrites. Columnar stromatolites are rare except for regionally extensive bioherms that mark the base of the formation in southern exposures (Swett and Knoll, 1985; see below).

For the most part, the intraclastic conglomerates and dolomicrites exhibit petrographic evidence for early marine diagenesis. In contrast, horizons containing abundant stratiform microbial laminae commonly contain evidence of subaerial exposure, leaching, oxidation, and vadose as well as artesian cementation (Fairchild et al., in press). As documented more completely elsewhere (Fairchild et al., in press) and discussed below in the context of individual fossil assemblages, the Draken Conglomerate Formation was deposited during one of the lowest sealevel stands represented within the Akademikerbreen Group. Draken dolomicrites record the deposition of carbonate mud, possibly from whitings, in a protected lagoon. Decimeter-scale intraclastic carbonates were deposited in the lagoons during storms, whereas oolites and oncolites originated in shoals that presumably formed the seaward lagoonal barrier. In situ stratiform mats and associated thinly bedded intraclastic units were deposited landward of the lagoons on extensive tidal flats.

Draken carbonates were deposited during the Late Riphean
Era, and probably during the latter part of this interval. This conclusion is supported by their stratigraphic position some 700 $\mathrm{m}$ below the lowermost Varangian (lower Vendian) tillite in Spitsbergen (Hambrey, 1982) and by the presence in Draken and surrounding formations of acritarchs and vase-shaped microfossils known only from rocks ca 850-650 Ma old. Carbon isotopic ratios in Akademikerbreen carbonates and organic matter approximate those of other 700-800 Ma old rocks, but differ from older Neoproterozoic successions (Knoll et al., 1986). Preliminary correlation of the Akademikerbreen Group with welldated successions in northwestern Canada by means of acritarch biostratigraphy and carbon and strontium isotopic chemostratigraphy suggests that the Draken carbonates post-date $780 \mathrm{Ma}$ old dikes that intrude correlative beds in the Canadian Cordillera (Knoll et al., unpublished data). If confirmed, this will provide a strong lower boundary for Draken deposition. For now, a broad age assignment of 700-800 Ma seems reasonable.

\section{TAXONOMY AND TAPHONOMY}

The principal interpretations in this paper are paleoecological, but such conclusions are necessarily built on a solid foundation of systematic paleontology and taphonomic understanding. In this paper, frequent reference is made to species and diversity, and many populations are given Linnean binomial names. To what extent are we justified in borrowing such concepts and procedures from biology, and what allowance must be made in paleobiological interpretation?

Taphonomy. - Taphonomy has been applied widely in the study of fossil vertebrates, invertebrates, and, increasingly, plants. There is widespread appreciation that some organisms and, indeed, parts of organisms are more likely to be preserved than others, that some environments are more likely to be represented by fossil assemblages than others, and that post-mortem transport has significant but predictable and detectable consequences for fossil accumulations. These generalizations are derived from numerous actualistic studies and specific ancientmodern comparisons (e.g., Behrensmeyer and Kidwell, 1985).

For nearly 20 years, comparable studies have illuminated the Proterozoic microfossil record, with broadly similar results. Within organisms, degradationally resistant walls, sheaths, or envelopes are differentially likely to become incorporated into the fossil record. To the extent that systematic studies of living microorganisms rely on ultrastructural or biochemical features, this indicates a significant loss of information. However, as illustrated by the paradigmatic study of the living cyanobacterium Entophysalis and its Paleoproterozoic counterpart Eoentophysalis (Golubic and Hofmann, 1976), preserved envelopes may provide morphological information comparable to that obtainable from populations of living organisms. Thus, in favorable circumstances, fossil cell-wall or envelope populations may justifiably be treated as biological entities, even though systematic relationships may not be clear at the phylum or even kingdom level.

Within environments, organisms that produce organic "hard parts" are differentially likely to be preserved. This is illustrated by actualistic studies of Recent microbial mat communities in which some cyanobacterial and flexibacterial sheaths as well as protistan cysts survive early biological decomposition, while more diverse bacterial heterotrophs disappear without a (morphological) trace (e.g., Horodyski and vonder Haar, 1975; Aizenshtat et al., 1984). Among environments, probability of preservation also varies, for two different reasons. The first is that the physico-chemical conditions promoting microfossil preservation (e.g., anoxia) are variably distributed among environments. The second is that organisms likely to produce 


\section{DRAKEN \\ BACKLUNDTOPPEN MACDONALDRYGGEN AREA}

\section{POLARISBREEN VETTENE AREA}

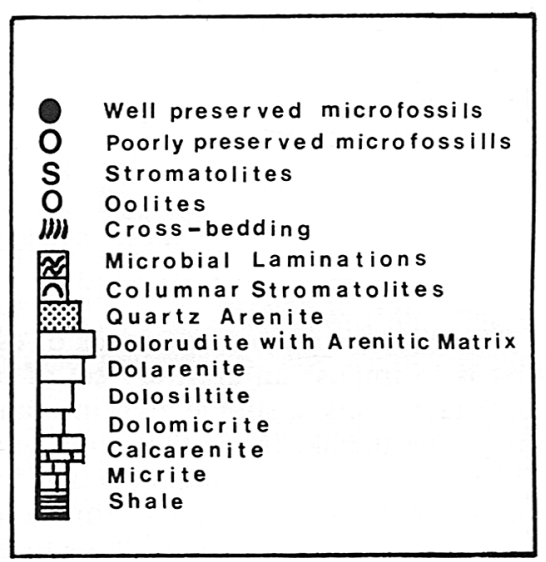

or likely to be equally early in all environments (Yin, 1987; Maliva et al., 1989). Fortunately, the peritidal facies that constitute the Draken Formation are among those in which early diagenetic chert emplacement is most likely. Equally fortunate, chert is not necessary for microfossil preservation. Some of the best preserved Neoproterozoic fossils come from siliciclastic mudstone (e.g., German, 1981; Jankauskas, 1982, 1989; Butterfield et al., 1988; Zang and Walter, 1989). In the Draken, well-preserved microfossils occur both in shales and in finegrained carbonates (where extremely local silica precipitation was sometimes important). Additional microfossil populations occur as carbonate-lined filaments comparable to Girvanella and other Phanerozoic fossils. These reinforce the observation that chert, carbonate, and clay can all provide physico-chemical conditions conducive to the preservation of life's early record. In this sense, the Draken biota is a microcosm of the Proterozoic fossil record as a whole. Comparison of populations preserved in different minerals is not always straightforward, and is aided markedly by morphological complexity or, as seen in a few Draken occurrences, by the ability to trace individual assemblages across preservational boundaries.
Most Draken fossils are preserved in early diagenetic chert nodules. This preservation itself introduces some environmental bias, in that diagenetic chert formation is not equally likely 
Taxonomy. - Some of Proterozoic paleontology's most difficult problems stem from its greatest success, the demonstration that Proterozoic rocks are abundantly fossiliferous. Early and influential monographs (e.g., Timofeev, 1959; Barghoorn and Tyler, 1965; Schopf, 1968) were published before the importance of taphonomy and populational variability was widely appreciated. Building on these, subsequent publications have resulted in a minor jungle of taxonomic names, many supported by the barest of description or illustration.

There are two potential means of escaping this jungle. The first is to impose an arbitrary set of morphologically defined form taxa. This is simple and, in many ways, efficient, but it minimizes the likelihood that Linnean names will mean much. The second way is to conduct detailed populational studies informed by taphonomy and sedimentology-only defining taxa when there is sufficient information to make clear demarcations among species. This minimizes our ability to compare populations among (and sometimes, even within) formations, but it maximizes the biological significance of those interpretations that can be made.

In practice, systematic paleontology is a combination of both. Some taxa, such as species of Eoentophysalis, Trachyhystrichosphaera, or Polybessurus, are circumscribed by a number of characters and surely come close to the meanings understood by neontological taxonomists for microbial species and genera. At the other extreme are simple form taxa that may be differentiable into populations within local assemblages, but whose comparison across time and space has limited significance. Two brief examples illustrate the difficulties that form taxa pose for paleoecological interpretations, as well as the paths we have chosen in our attempts to surmount these difficulties.

Among the most common fossils in Neoproterozoic cherts are spheroidal vesicles referred to the form genus Myxococcoides. In his original diagnosis, Schopf (1968) stressed the absence of individual envelopes and the presence of amorphous mucilage in colonies. Myxococcoides was distinguished from the genera Glenobotrydion and Caryosphaeroides on the basis of dense internal organic structures and internal organic structures surrounded by a partially collapsed "inner wall layer," respectively. Subsequent research has shown internal cellular remains to be fickle characters (Hofmann, 1976; Knoll, 1981). Although typically constant within a single Bitter Springs cluster, these internal organic bodies are not invariably so, and there is no other way to differentiate populations consistently. The occasional arrangement of vesicles in uniseriate pseudofilaments (Schopf, 1968) may be significant at the species level. In this paper, we have not considered internal organic blebs to be taxonomically significant.

Having resolved one taxonomic difficulty, another remains. The genus Gloeodiniopsis is differentiated from Myxococcoides by its multiple envelopes that surround an internal vesicle and by its common retention of 2-8 daughter cells within the external envelope (Schopf, 1968; Knoll and Golubic, 1979). This distinction follows directly from Schopf's diagnosis of Myxococcoides and provides a ready means of differentiating populations in the Bitter Springs Formation. Problems arise, however, in the determination of populations that differ in only one of the two characters used to differentiate genera. In the Draken Formation, there occur spheroidal populations that have both internal and external layers, but no record of binary division. Knoll (1982) originally assigned these populations to Gloeodiniopsis gregaria, but restudy indicates that these populations form one end member of a morphological continuum running to typical Myxococcoides cantabrigiensis. Single clusters may include specimens with a well-defined internal "wall" adjacent to empty vesicles. Therefore, in this study, we reserve the name Gloeo- diniopsis for populations that exhibit both multiple envelopes and 2-8 daughter cells within a common envelope. This still does not solve all problems caused by variable preservation of envelopes; in some populations it is the external envelope that is differentially vulnerable to degradation, whereas in others it is the internal vesicle. This distinction may prove taxonomically useful, but the plain fact is that when preservation is sub-optimal (i.e., most of the time), precise systematic assignment may not be possible. This puts an important constraint on the paleoecological and evolutionary comparisons of assemblages.

A second problem concerns the filamentous sheaths that form the bulk of the Draken and many other mat assemblages. Schopf (1968) erected three genera (Eomycetopsis, Siphonophycus, and Tenuofilum) to encompass nonseptate or inconspicuously septate filaments in the Bitter Springs Formation. Although the logic behind recognition of three genera was reasonable, subsequent research has shown that the three taxa are all the aseptate sheaths of cyanobacteria comparable to Lyngbya, Phormidium, Plectonema (LPP-type cyanobacteria), or morphologically similar flexibacteria (Hofmann, 1976; Knoll, 1981). The taxa differ only in size, but in this character Bitter Springs populations (and Draken populations) are cleanly differentiable. We have synonymized the three genera into Siphonophycus and consider five species to be present in Draken cherts (see Systematic Paleontology section for further discussion). One might ask whether the species recognized might come from a single biological population of sheaths locally shrunken or expanded during diagenesis. This seems unlikely both because size is relatively invariant within populations and because mat fabrics commonly differ, indicating that parent populations differed in behavior as well as morphology.

In this study, then, taxa are recognized on the basis of consistently observable biological characteristics and interpreted in light of modern analogs found in comparable environmental settings. Our reluctance to recognize distinct taxa when differentiating characters that are possibly or probably of taphonomic origin results in a conservative estimate of species richness. Perhaps half of the species recognized are sufficiently distinctive that their biological integrity seems assured, facilitating comparisons among basins. Other species, however, while clearly differentiable within the Draken biota, remain form taxa whose biological relationships to morphologically similar populations in other basins cannot be assumed. As in classical taxonomic treatments of living cyanobacteria (e.g., Geitler, 1930-1932), fossil genera are differentiated on the basis of qualitative differences among populations; species within genera are differentiated on the basis of quantitative differences.

\section{MICROFOSSIL ASSEMBLAGES}

In situ stratiform stromatolites. - Within the Draken Conglomerate Formation, many of the best preserved microfossils occur in redeposited clasts, complicating paleoenvironmental interpretation. In the upper part of the formation, however, silicified, microbially laminated carbonates preserve a record of in situ mat communities that provides a key to the interpretation of intraclasts elsewhere in the succession.

The rocks in questions are stratiform stromatolites up to one meter thick, which are interbedded with dolarenites and thin shaly units (Figure 3.1). Laminae are flat to slightly undulatory and about one mm thick. Isolated low, irregular domes occur in several beds (Figure 3.2), but these appear to be a product of soft-sediment deformation, at least in part. Syndepositional deformation is independently documented by tepees that occur in the same sections. The stromatolites are dolomitic. Patchy silicification occurred early in diagenesis, but chert emplacement post-dates soft-sediment deformation (Figure 3.2). In the Po- 
larisbreen area, quartz and carbonate sand grains are important constituents of laminated rocks, and dolarenite interbeds are abundant. To the south, along MacDonaldryggen and Backlundtoppen nunataks, arenitic material is less common. These carbonates exhibit petrographic evidence of subaerial exposure and cementation from vadose and saline artesian groundwaters (Fairchild et al., in press). They apparently accreted under upper intertidal to supratidal conditions on the broad Draken tidal flat.

Reasonably well-preserved fossil assemblages (Table 1) occur at MacDonaldryggen (samples M-20 and M-21; see Figures 1 and 2) and Backlundtoppen (B-165, B-550, B-625, B-670). In fossiliferous samples, stromatolitic microfabric is preserved in uniformly fine-grained silica, with no evidence that quartz or carbonate grains larger than silt were trapped and bound (Figure 3.3). Individual laminae are $0.5-3.0 \mathrm{~mm}$ thick and are differentiated largely by relatively strong organic pigmentation at lamina tops. Although many laminations appear unfossiliferous at first glance, closer inspection reveals densely tangled filaments preserved as "ghosts." Irregularly distributed patches of wellpreserved fossils (Figure 3.4) confirm that the mats were built by dense populations of filamentous microorganisms whose surviving sheaths are assigned to the form species Siphonophycus kestron and $S$. inornatum. These sheaths have unusually thick walls $(>1 \mu \mathrm{m})$, and their large size suggests that they were formed by cyanobacteria rather than anoxygenic photobacteria. Each of these taxa forms essentially monospecific mats that can be interlaminated within a single rock sample. In general, filaments exhibit no preferred orientation, but in a few laminae populations display a distinctly vertical alignment. Siphonophycus kestron mats may contain an admixture of large (cross-sectional diameter $>20 \mu \mathrm{m}$ ) Siphonophycus capitaneum sheaths, and scattered Myxococcoides vesicles occur in some laminae.

Taphonomy undoubtedly contributes to the observed low species richness of the in situ mat assemblage, but there are reasons for believing that these mats had a relatively low original diversity. Even within the highly diverse lower flake conglomerate assemblage (see below), most mats have a single-builder population; high species richness is largely a function of diverse mat dwellers and allochthonous populations. In the lower flake conglomerate assemblage, it can be demonstrated that these dwellers and allochthonous microfossils are preserved differentially well relative to builders (see below). Thus, it is unlikely that the low species richness of the in situ mats is a strong function of preferential decay; it reflects a low original abundance and diversity of mat dwellers and washed-in elements. This is consistent with modern microbial mats, where diversity is often inversely proportional to exposure or other environmental stress (Golubic, 1976; Whitton and Potts, 1982; see also Green et al., 1989). The robust sheaths characteristic of this assemblage also bear comparison with those of mat-builders in Recent upper intertidal to supratidal environments; thick extracellular sheaths and envelopes protect cells from desiccation and potentially harmful solar radiation (Bauld, 1981, 1986).

Upper flake conglomerate assemblage. - Silicified dolarenites and fine-grained flake conglomerates from uppermost Draken beds in MacDonaldryggen and Draken nunataks contain wellpreserved microbial mat assemblages that link them genetically (in part) to the aforementioned in situ mats. The fossiliferous units occur within a complex interleaving of thin microbially laminated beds, flake conglomerates, dolarenites, pisolites, and black shale (Wilson, 1961). Chert is common in the clastic carbonates, occurring as nodules to more or less continuous beds up to a meter thick (in reality, very long nodules formed during early diagenesis). The fossiliferous flake conglomerates and dolarenites document the erosion of tidal-flat sediments and their redeposition in sheets or broad shallow channels within the intertidal zone (Fairchild et al., in press).

Sample J-1047, from Draken nunatak, is particularly informative. As seen in thin section, this sample consists of cm-scale beds that grade from thin flakes $(<1 \times 1-3 \mathrm{~mm})$ without matrix to arenite (Figure 3:5). Flake horizons are pervasively silicified, displaying chalcedonic, void-filling cement and little intergranular compaction. In contrast, the arenitic zones contain substantial dolomite and are compacted so that there is little minuscement porosity. Most of the flakes are fossiliferous, and almost all are redeposited microbial mat shards; few arenitic grains contain fossils.

The composition of the upper flake assemblage is shown in Table 2. Eighty-seven percent of all fossiliferous flakes contain dense populations of Siphonophycus inornatum, S. kestron, or mixed $S$. inornatum and $S$. capitaneum sheaths (Table 3; Figures $3.6,3.7,4.1)$. That is, most of the flakes are clearly derived from supratidal to upper-intertidal mats comparable to those described in the previous section. Three percent contain matbuilders different from those found in the in situ mat assemblage-specifically, Siphonophycus septatum and Polytrichoides lineatus, a form taxon differentiated by its tendency for sheaths to occur in coiled bundles of 6-12 filaments (Figure 4.3, 4.5). The remaining 10 percent of the fossiliferous clasts contain a diverse assemblage that includes Myxococcoides spp., Polybessurus bipartitus, Sphaerophycus parvum, Eosynechococcus spp., Synodophycus euthemos, and Gloeodiniopsis mikros (Figure 4.7). This assemblage resembles the lower flake conglomerate biota originally reported by Knoll (1982) and described in greater detail below.

Additionally, sample J-1047 contains apparently planktonic fossils in the intergranular space. Many of these are Myxococcoides cantabrigiensis clusters (Figure 4.2), but moderately wellpreserved specimens of large acritarchs, including the morphologically complex Trachyhystrichosphaera vidalii (Figure 4.8) and Cymatiopsphaeroides kullingii (Figure 4.4, 4.6), occur as well. These distinctive Neoproterozoic microfossils are also found in the subtidal silicified carbonate assemblage and in shallow subtidal facies elsewhere in the Akademikerbreen Group and its equivalents (Knoll and Calder, 1983; Knoll, 1984; Butterfield and Knoll, 1989), substantiating their interpretation as coastalmarine plankters that were washed onto tidal flats. This facies association contrasts with Zang and Walter's (1989) suggestion that large complex acritarchs indicate offshore Proterozoic environments (see also Knoll and Butterfield, 1989). The systematic, paleoecological, and evolutionary interpretation of $T$. vidalii is discussed below.

Subtidal carbonates and silicified carbonates. -Among the most remarkable assemblages in the Draken Conglomerate are those preserved in lagoonal dolomicrites and their silicified equivalents. The sediments in question are fine-grained carbonates deposited in thin, slightly irregular to subparallel beds a few to $20 \mathrm{~mm}$ thick. The beds contain abundant particulate organic matter, often as wispy fragments of mats or, possibly, seaweeds (Figure 5.4). A few continuous mat horizons up to several $\mathrm{mm}$ thick are intercalated, as are thin dolosiltites and dolarenites. Dolomicrite beds may be truncated by dolarenites displaying low-angle cross-stratification. Chert occurs as continuous nodules, internal molds of vase-shaped microfossils and filamentous microorganisms, and $\mu \mathrm{m}$-scale micronodules nucleated on particulate organic matter (Figures 5.5, 6.1, 6.2). Pervasive alteration of carbonates to dolomite followed silicification.

Schieber (1989) recently published a facies classification of Proterozoic shales based on the Middle Proterozoic Belt Supergroup. Textural and bedding characteristics of the Draken 

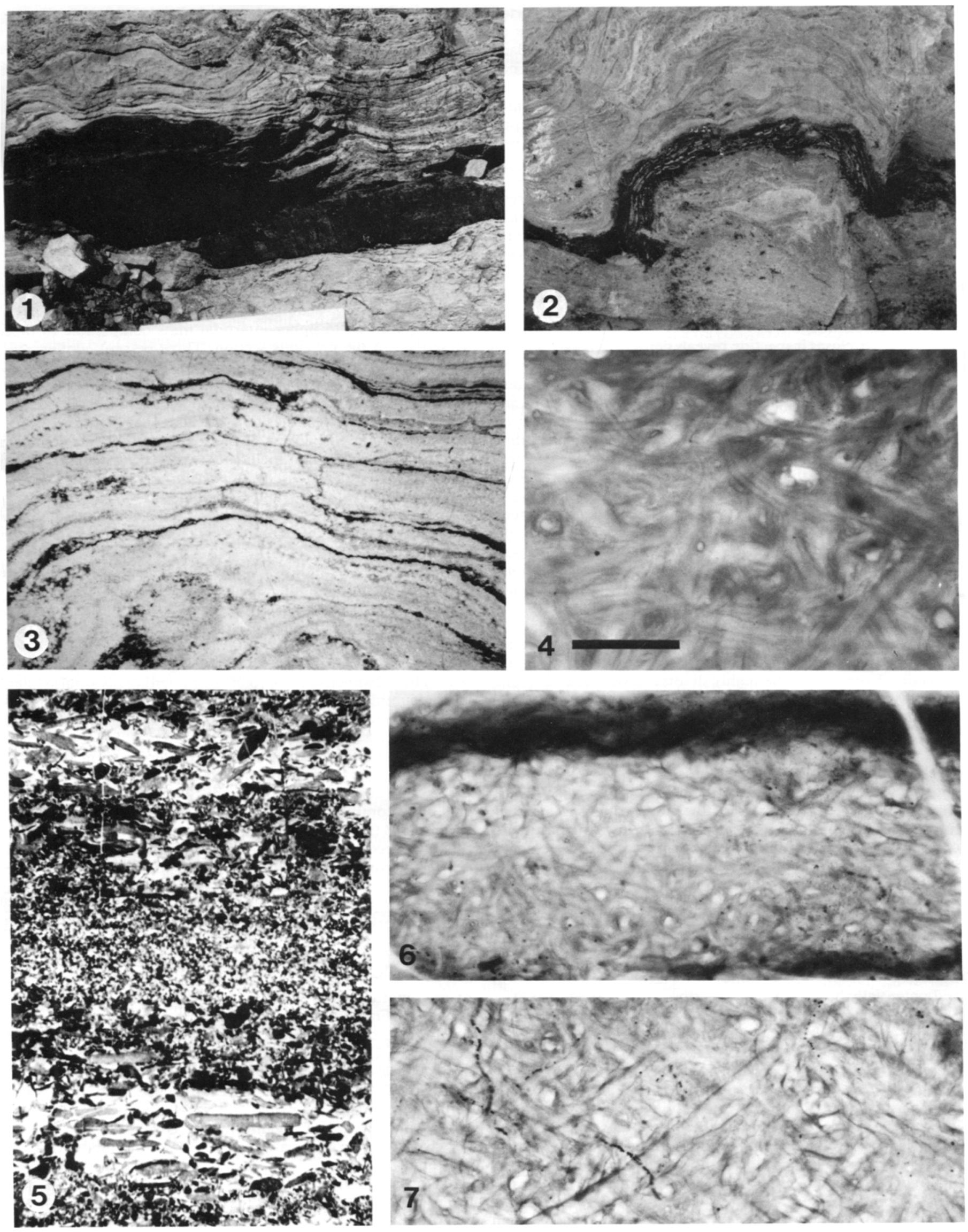
sediments do not conform in their entirety to any one of Schieber's shale types, but they do exhibit features that Schieber associated with his "carbonaceous swirl" and "striped" shales. These facies are interpreted as having been deposited subtidally between fair-weather and weak to average storm wave bases (Schieber, 1989). It is likely, therefore, that the Draken dolomicrites accumulated in a normally low-energy subtidal environment subject to episodic storms. As this environment lay adjacent to tidal flats, it was probably a protected lagoon broadly comparable to those forming today behind reefs or bars, or a wide shallow platform leeward of the tidal flat and land. A subtidal interpretation is corroborated by vase-shaped microfossils and acritarchs known to have broad geographic distribution in shallow subtidal marine sediments of Neoproterozoic age. These fossils are essentially absent from intertidal Draken mats.

Exceptional preservation of filamentous microorganisms as siliceous (or, less conspicuously, dolomitic) internal molds (Figure 5.1-5.3, 5.6) shows that at least some of these subtidal carbonates supported microbenthic populations capable of stabilizing fine-grained sediments. The casts are 13-60 $\mu \mathrm{m}$ in crosssectional diameter and up to $500 \mu \mathrm{m}$ long; filaments are oriented approximately perpendicular to bedding and display rare but clear branches (Figure 5.2, 5.3). No traces of carbonaceous walls or sheaths are preserved; nor is there evidence for filament calcification or tufa deposition. The filaments appear to have been buried in carbonate mud, following which early diagenetic silica emplacement insured a fossil record despite oxidation, compaction, neomorphism, and dolomitization.

The systematic interpretation of these fossils is problematic. Their size and branching habit clearly distinguish them from any of the mat-builders found in the intertidal assemblages. The gross morphology of the tubes invites comparison with molds of the cyanobacterial filament Scytonema reported from levees and freshwater algal marshes of Andros Island (Monty, 1967; Hardie, 1977). Like the Draken filaments, Scytonema species branch; however, several observations discourage too close a comparison. According to Black (1933) and Monty (1967), Andros Scytonema populations are inhibited by salinities approaching that of normal sea water, but there is nothing in this Draken facies to suggest fresh or brackish water. Sedimentary features associated with the Andros filaments, such as tufa and fenestrae, are absent from the Draken carbonates in question. Indeed, while reasonable, an assumption of cyanobacterial affinity is not necessarily correct. Riding (1979) has described filamentous molds of the probable green alga Cladophorites in lacustrine bioherms from the Miocene of Germany. Once again, the petrological characteristics of the Cladophorites carbonates do not match those of the Draken samples, but Riding's work establishes the point that eukaryotic algae can produce casts and molds comparable to those found in the Draken. Subtidal siliciclastic mudstones from the Svanbergfjellet Formation (immediately subjacent to the Draken) contain carpets of possible cladophoralean algae whose general size and branching fre-
TABLE 1-Taxa present in the in situ mat assemblage (samples $M-20$, $\mathrm{M}-21, \mathrm{~B}-550$, and B-670).

\begin{tabular}{|c|c|c|}
\hline Taxon & Size $(\mu \mathrm{m})^{1}$ & Comments \\
\hline $\begin{array}{l}\text { Siphonophycus kestron } \\
\text { Siphonophycus inornatum } \\
\text { Siphonophycus capitaneum }\end{array}$ & $\begin{array}{r}11.0(0.9) \\
5.1(0.8) \\
17.3(3.9)\end{array}$ & $\begin{array}{l}\text { Principal mat-builder } \\
\text { Principal mat-builder } \\
\text { Auxiliary mat-builder in } \\
S \text { inornatum mats }\end{array}$ \\
\hline Myxococcoides spp. & $8.0-18.0$ & Scattered in mats \\
\hline
\end{tabular}
${ }^{1}$ Mean and standard deviation (in parentheses) or observed range for
maximum diameter (cross-sectional diameter for filamentous fossils).

quency approach those of the Draken tubes (Butterfield et al., 1988).

Other microfossils in the subtidal carbonate facies include abundant siliceous internal molds of vase-shaped microfossils (Figure 7.1-7.3), common Myxococcoides cantabrigiensis individuals and clusters (Figure 6.1, 6.2), scattered leiosphaerid acritarchs, and, of particular interest, Trachyhystrichosphaera vidalii (Figure 7.4-7.8). The Trachyhystrichosphaera population is sufficiently large to permit confident determination of its basic morphology and within-population variability.

The genus Trachyhystrichosphaera (type species $T$. animika) was established by German (in Timofeev et al., 1976) for microfossils from the Upper Riphean Lakhanda Formation of eastern Siberia. Knoll (1984) described a second species, $T$. vidalii, from subtidal cherts of the Upper Riphean Hunnberg Formation, Nordaustlandet, Svalbard. The genus is now known to occur in late Riphean to (?)Vendian rocks from additional localities in Siberia (Pjatiletov, 1988; Jankauskas, 1989), the southern Urals (Jankauskas, 1982), Svalbard (Knoll and Calder, 1983; Butterfield and Knoll, 1989), Alaska (Allison and Awramik, 1989), and Arctic Canada (Butterfield and Knoll, 1989). Seven species have been described, but not all are well differentiated.

Trachyhystrichosphaera acritarchs are large spheroidal vesi-

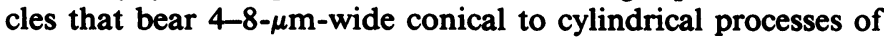
variable length and distribution (German in Timofeev et al., 1976). Processes are hollow and open to the vesicle interior. In $T$. vidalii, this process-bearing inner vesicle is enveloped in a thin outer vesicle whose surface may or may not mirror the projections of processes (Figure 7.8). Most previously described populations contain few individuals, and the size ranges reported are 250-700 $\mu \mathrm{m}$; however, the Draken population indicates that $T$. vidalii individuals could reach the truly macroscopic size of $2,700 \mu \mathrm{m}$. (One 4,200- $\mu \mathrm{m}$ vesicle was found among the $T$. vidalii population, but as processes could not be identified with certainty, this specimen has not been included in the censused population.) The size frequency distribution of a sample population is shown in Figure 8 . The mean diameter is $913 \mu \mathrm{m}\left(\mathrm{s}_{\mathrm{x}}=490 \mu \mathrm{m}\right)$, and the median is $790 \mu \mathrm{m}$. (Note that these measurements were made on specimens observed in thin sections. Insofar as some specimens may be represented by tangential rather than equatorial slices, these diameters must be

FIGURE 3-Facies and microfossils of the stratiform stromatolite and upper flake conglomerate assemblages. In this and all following figures, slide number, England Finder coordinates, and Harvard University Herbaria Paleobotanical Collection catalog number are given for each microfossil or population illustrated. 1,2 , outcrop photographs of in situ stratiform stromatolites showing early diagenetic chert (dark areas); doming in 2 is probably due to soft-sediment deformation; 3 , thin-section view of silicified stratiform stromatolite, showing irregular lamination (highlighted here by dark, dolomite-rich layers); light coloration is provided by preserved filamentous microfossils; 4, dense mat of Siphonophycus inornatum and $S$. capitaneum in in situ stratiform stromatolites (P-670-2A, E25/1, HUHPC \#62356); 5, thin-section view of upper flake conglomerate, showing grading between arenitic and small flake (mostly mat fragments) clasts; 6,7 , clasts of mixed $S$. inornatum $/ S$. capitaneum mats from upper flake conglomerate (6, J-1047-1A, N20/4, HUHPC \#62357; 7, J-1047-2, K23-4, HUHPC \#62357). Ruler in 1 is 15 mm long; for other photographs, the bar in $4=4 \mathrm{~cm}$ for $2 ;=4 \mathrm{~mm}$ for $3 ;=100 \mu \mathrm{m}$ for 4 and $7 ;=2 \mathrm{~mm}$ for 5 ; and $=200 \mu \mathrm{m}$ for 6 . 

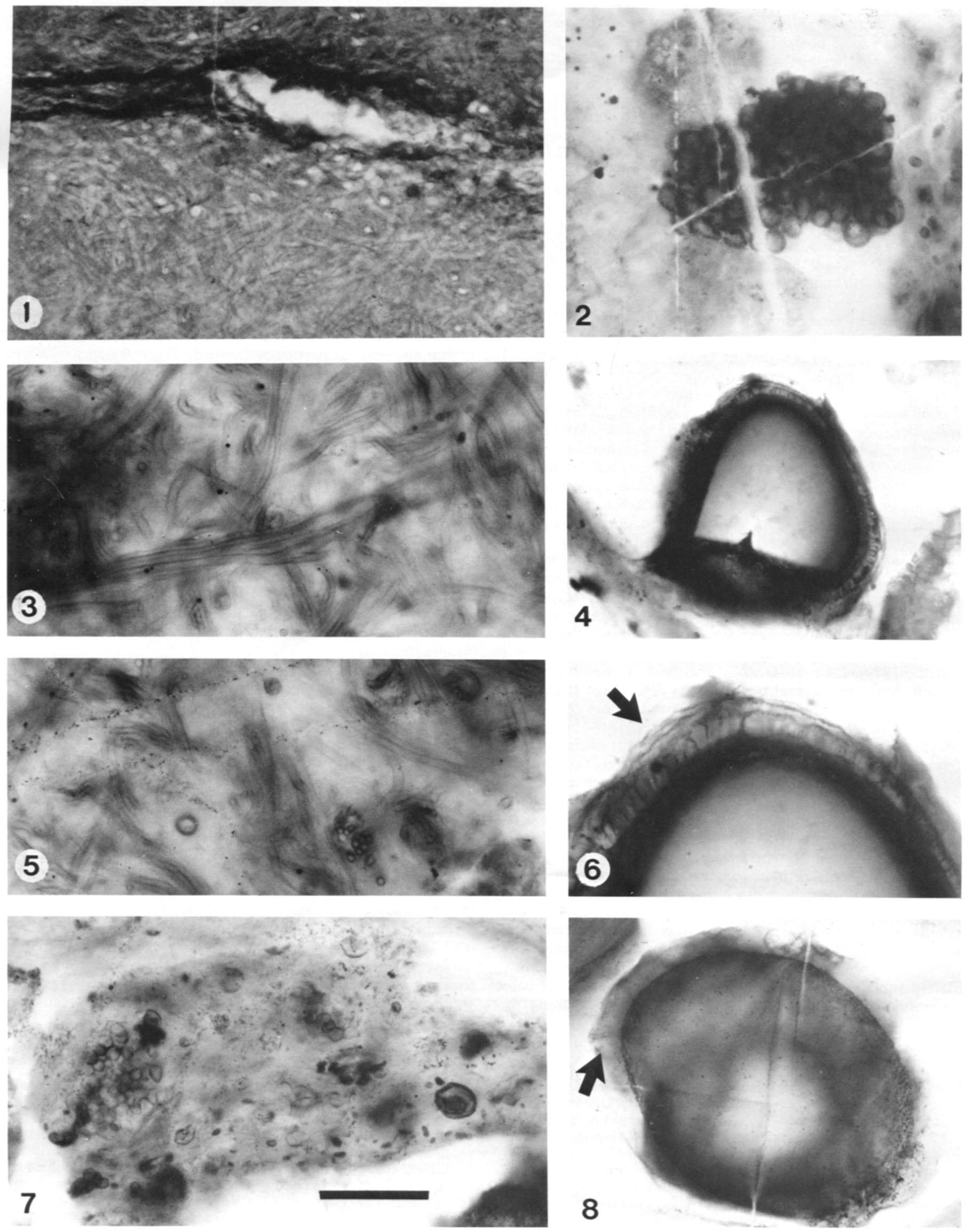
TABLE 2-Taxa present in the upper flake conglomerate assemblage [samples J-1047, B-625, and M-31 (partim)].

\begin{tabular}{|c|c|c|}
\hline Taxon & Size $(\mu \mathrm{m})^{1}$ & Comments \\
\hline $\begin{array}{l}\text { Siphonophycus kestron } \\
\text { Siphonophycus inornatum } \\
\text { Siphonophycus capitaneum }\end{array}$ & $\begin{array}{r}11.0(1.4) \\
4.7(0.6) \\
17.0(2.0)\end{array}$ & $\begin{array}{l}\text { Principal mat-builder } \\
\text { Principal mat-builder } \\
\text { Auxiliary mat-builder in } \\
\quad S \text {. inornatum mats }\end{array}$ \\
\hline Polytrichoides lineatus & $3.6(0.7)$ & $\begin{array}{l}\text { Rare principal mat- } \\
\text { builder }\end{array}$ \\
\hline $\begin{array}{l}\text { Myxococcoides spp. } \\
\text { Polybessurus bipartitus }\end{array}$ & $\begin{array}{r}8.0-25.0 \\
35.0-75.0\end{array}$ & $\begin{array}{l}\text { Scattered within mats } \\
\text { Restricted to rare high di- } \\
\text { versity clasts }\end{array}$ \\
\hline Gloeodiniopsis mikros & $5.5(0.9)$ & $\begin{array}{l}\text { Restricted to rare high di- } \\
\text { versity clasts }\end{array}$ \\
\hline Synodophycus euthemos & $5.0-7.0$ & $\begin{array}{l}\text { Restricted to rare high di- } \\
\text { versity clasts }\end{array}$ \\
\hline Eosynechococcus brevis & $2.0-4.0$ & $\begin{array}{l}\text { Restricted to rare high di- } \\
\text { versity clasts }\end{array}$ \\
\hline Eosynechococcus medius & $5.0-8.0$ & $\begin{array}{l}\text { Restricted to rare high di- } \\
\text { versity clasts }\end{array}$ \\
\hline Siphonophycus septatum & ca 1.0 & $\begin{array}{l}\text { Restricted to rare high di- } \\
\text { versity clasts }\end{array}$ \\
\hline $\begin{array}{l}\text { Trachyhystrichosphaera } \\
\text { vidalii }\end{array}$ & $410-500$ & $\begin{array}{l}\text { Rare in intergranular } \\
\text { chert }\end{array}$ \\
\hline $\begin{array}{l}\text { Cymatiosphaeroides } \\
\text { kullingii }\end{array}$ & 140 & $\begin{array}{l}\text { Rare in intergranular } \\
\text { chert }\end{array}$ \\
\hline Large leiosphaerid & 650 & $\begin{array}{l}\text { Rare in intergranular } \\
\text { chert }\end{array}$ \\
\hline
\end{tabular}

' Mean and standard deviation (in parentheses) or observed range for maximum diameter (cross-sectional diameter for filamentous fossils).

considered minimum figures.) Small individuals tend to have a relatively high density of processes. Also, processes are of varying length, even within individuals, suggesting that new processes continued to erupt as vesicles increased in size. These observations suggest that the vesicle-producing stage of $T$. vidalii was not dormant, but rather metabolically active and capable of continued growth. Among extant algae, this phenomenon is seen in the prasinophycean green algae (Tappan, 1980). Prasinophyte life cycles alternate between a motile phase and a nonmotile phycoma-producing stage. The phycoma is a degradation-resistant wall that expands as the enveloped cell grows. In modern prasinophytes, the cell may increase in volume 5,000 times or more before multiple mitoses produce a new generation of motile cells (Tappan, 1980).
Draken $T$. vidalii specimens commonly display internal organic contents, which demonstrate that these vesicles contained a single large cell (Figure 7.5). As outlined above, it is likely that this encysted cell was metabolically active, altering the morphology of its vesicle as it grew. The size range of Draken specimens indicates a minimum volumetric increase of 500 -fold, well within the range exhibited by living prasinophytes. Thus, the features of $T$. vidalii are consistent with its interpretation as the phycomata of (unusually large) Neoproterozoic prasinophytes. That interpretation is provisionally accepted here, although we stress its uncertainties. With even less certainty, many of the leiosphaerid acritarchs found abundantly in Proterozoic rocks have been attributed to the Prasinophyceae (Muir and Sarjeant, 1971; Tappan, 1980; Vidal and Knoll, 1983).

Lower flake conglomerate assemblage. - This facies contains the best preserved and most diverse microfossils in the Draken Formation. Originally described from a single locality in Dracofjella, on the northern side of Polarisbreen (Knoll, 1982), this assemblage has now been found in localities elsewhere in Dracofjella and in Vettene, MacDonaldryggen, and Backlundtoppen nunataks (especially samples P-13, P-91, B-165, M-11, M-12, $M-13$, and $M-28$ ). In all cases, the fossils occur in silicified clasts within dm-scale flake conglomerate beds (Figure 9.1-9.3). The beds commonly exhibit unidirectional cross-lamination with set thicknesses of up to $10 \mathrm{~cm}$. These flake conglomerates are interbedded with, and commonly truncate, lagoonal dolomicrites. This sedimentary association and petrographic evidence indicating that early diagenesis occurred under the influence of marine pore waters, with limited evidence for subaerial exposure or leaching, suggest that these flake conglomerates formed when storms ripped up and redeposited locally derived clasts in subtidal lagoons (Knoll, 1982; Fairchild et al., in press).

Some fossiliferous flakes were clearly derived from the lagoonal micrite facies (Table 3), but others cannot be related to in situ sediments. These include clasts of biologically diverse microbial mats built by Siphonophycus inornatum or $S$. septatum (Figures 6.4-6.6, 10-19). The presence in these clasts of populations whose living counterparts are intertidal and the absence of organisms indicative of subtidal deposition (e.g., vase-shaped microfossils or Trachyhystrichosphaera) suggest that such clasts originated on the tidal flats. It is possible that the exceptional preservation of microfossils in this facies relates to

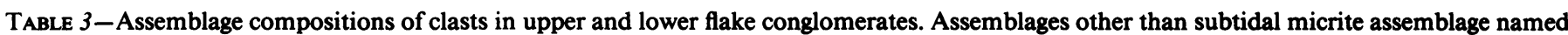
according to dominant mat-building taxa. Abundances recorded as the percentage of clasts characterized by each assemblage.

\begin{tabular}{|c|c|c|c|c|c|}
\hline \multirow[b]{3}{*}{ Assemblage type } & \multicolumn{5}{|c|}{ Facies } \\
\hline & \multirow{2}{*}{$\begin{array}{c}\text { Upper flake } \\
\text { conglomerate } \\
\text { (sample number) } \\
\text { J-1047 }\end{array}$} & \multicolumn{4}{|c|}{$\begin{array}{l}\text { Lower flake conglomerate } \\
\text { (sample numbers) }\end{array}$} \\
\hline & & P-91 & M-13 & W-839 & P-13 \\
\hline S. kestron mat & 16 & 0 & 0 & 0 & 2 \\
\hline$P$. lineatus mat & 1 & 0 & 0 & 0 & 0 \\
\hline Mixed $S$. inornatum/S. capitaneum mat & 16 & 0 & 0 & 0 & 4 \\
\hline S. inornatum mat (thick sheath, low diversity) & 55 & 0 & 6 & 3 & 20 \\
\hline S. inornatum mat (thin sheath, high diversity) & 10 & 13 & 21 & 19 & 30 \\
\hline S. septatum mat & 2 & 47 & 23 & 28 & 22 \\
\hline Subtidal micrite assemblage & 0 & 27 & 39 & 16 & 10 \\
\hline Indeterminate & 0 & 13 & 11 & 25 & 12 \\
\hline
\end{tabular}

FIGURE 4-Microfossils from the upper flake conglomerate facies. 1, Siphonophycus kestron (lower) and S. inornatum (upper) mats in a clast (J1047-1A, A19/2, HUHPC \#62358); 2, Myxococcoides cantabrigiensis in intergranular space (J-1047-1A, T40/4, HUHPC \#62359); 3, 5, Polytrichoides lineatus mat clast (J-1047-1, Y27/4, HUHPC \#62360); 4, 6, Cymatiosphaeroides kullingii in intergranular space (detail showing multiple wall layers and processes at arrow; J-1047-1, Q24/0, HUHPC \#62361); 7, a relatively high diversity clast; 8, Trachyhystrichosphaera vidalii in intergranular space; note process visible at arrow $(\mathrm{J}-1047-1 \mathrm{~A}, \mathrm{D} 31 / 3, \mathrm{HUHPC} \# 62362)$. Bar in $7=200 \mu \mathrm{m}$ in 1 and $6 ;=80 \mu \mathrm{m}$ in 2,3 , and $5 ;=60 \mu \mathrm{m}$ in $4 ;=125 \mu \mathrm{m}$ in 7 and 8 . 
the sedimentary juxtaposition of tidal-flat microorganisms (with their degradationally resistant envelopes and walls), rapid burial during storms, and early diagenesis in a coastal-marine setting where the probability of early silicification is relatively high.

At least 32 taxa occur in these flake conglomerates (Table 5), but they do not occur as a homogeneous assemblage. As indicated in Table 3, at least three discrete associations can be differentiated: Siphonophycus inornatum-built mats, $S$. septatum-built mats, and subtidal muds containing vertical tubes of the type described in the preceding section. (Knoll, 1982, recognized a fourth mat type dominated by Siphonophycus (=Eomycetopsis) robustum, but that assemblage is here reinterpreted as a Siphonophycus septatum mat in which the auxiliary mat-builder $S$. robustum is differentially well preserved; Figure 10.3.) Siphonophycus inornatum mats in this facies differ from those characteristic of the in situ stratiform stromatolites and upper flake conglomerates. The sheaths of filamentous matbuilders are much less robust and are, correspondingly, more easily degraded. Also, the thin-sheathed $S$. inornatum mats contain as many as a dozen dweller species and abundant allochthonous microfossils belonging to at least four taxa. The $S$. septatum mats are comparably diverse, preserving two auxiliary builders (which never occur together), up to seven or eight dweller species, and extremely abundant allochthonous elements. Low diversity associations of the types characterizing in situ stratiform stromatolites and the upper flake conglomerate assemblage are rare or absent from this facies (Table 3).

Of the many taxa preserved in this facies, two may be singled out for special consideration. First is Polybessurus bipartitus, a morphologically distinctive stalk-forming microorganism (Figure 12). Polybessurus has been compared with modern $C y$ anostylon-like cyanobacteria that form crusts (and exclude clastic sediments) in upper intertidal to supratidal environments on Andros Island, Bahamas (Green et al., 1987). The major difference between the Neoproterozoic and living organisms is the significantly larger size of the fossils. In the Draken Conglomerate Formation, Polybessurus occurs only among $S$. inornatum mats. In clasts containing diverse taxa, Polybessurus occurs as isolated individuals or in small clusters, but in less diverse mats it sometimes forms monospecific crusts at least $3-4 \mathrm{~cm}$ in linear dimension. These are seen most clearly in silicified carbonates from correlative beds in the Eleonore Bay Group, central East Greenland (Green et al., 1987), but they can be observed in calcified microfossil assemblages in the Draken Formation (see below).

A second remarkable population occurs in a single thin lens in sample M-21 (Figure 13.1-13.4); the lens certainly originated within the $S$. inornatum/S. septatum mat zone, but where in that zone is uncertain. This lens contains what superficially appear to be several taxa: $12-15 \mu \mathrm{m}$ vesicles, larger vesicles up to $40 \mu \mathrm{m}$ in diameter, and vesicles containing a partially collapsed inner body. Several observations indicate that these all belong to a single entity. First, a few single clusters of cells include both empty vesicles and individuals containing a differentiated inner body. This demonstrates that within this pop- ulation, the presence or absence of an inner body is diagenetically determined. Second, single clusters may contain both large and small individuals, usually in distinct subpopulations. The biological basis of this size differential is revealed by one fortuitously preserved subpopulation in which large vesicles $(20$ $30 \mu \mathrm{m})$ contain closely packed smaller $(10-17 \mu \mathrm{m})$ cells that fill vesicle interiors (Figure 13.1-13.3). Of 43 such vesicles observed, 30 are clearly tetrads, 7 are dyads, 3 are octads, 1 is a monad, and 2 are not determinable (Figure 14). It is clear that upon reaching a certain size range and-to judge from the population - at infrequent intervals, cells underwent division to form smaller daughter cells that were then released. The observation that cells in dyads, tetrads, and octads have volumes slightly larger than half of their divisional precursors indicates that slow growth continued during the interval of cell division (Figure 14).

This population superficially resembles Gloeodiniopsis lamellosa, originally described from lacustrine cherts of the Bitter Springs Formation (Knoll and Golubic, 1979), but similarities are probably fortuitous. The Draken population shows no evidence of multiple envelopes, a key distinguishing feature of $G$. lamellosa. Further, whereas in $G$. lamellosa most individuals are preserved in some stage of cell division, evidence of division is found only in one small subpopulation of the Draken fossils. The systematic position of this population, described below as Myxococcoides chlorelloidea, is uncertain, but candidate modern counterparts occur among chlorococcalean green algae. The common alga Chlorella is quite similar morphologically (Francis et al., 1978; Pickett-Heaps, 1975). Like the fossils, Chlorella populations can exhibit significant size variation, and this can be exaggerated by a several-fold post-mortem expansion of cell walls (Francis et al., 1978; personal observation). The walls of at least some Chlorella species contain sporopollenin (Atkinson et al., 1972), increasing their likelihood of preservation. Vesicle size in the Draken population exceeds that for most living Chlorella, but given the common occurrence of post-mortem wall expansion, this does not present a major interpretational problem. Thus, the case for placing this population among the chlorococcalean green algae is reasonable; however, given the simplicity of the fossils, we cannot regard it as compelling and so formally regard this species as incertae sedis.

Calcified microbial assemblages. - Columnar stromatolites are not common in the Draken Conglomerate, but a conspicuous horizon of lithoherms (bioherms) marks the base of the formation in southern outcrops (Figure 20.1). The sedimentology and petrology of these stromatolites are described in detail elsewhere (Raaben, 1969; Swett and Knoll, 1985; Fairchild et al., in press). In brief, they can be characterized as tabular lithoherms 20 to more than $50 \mathrm{~m}$ long and 4-5 m thick that accumulated in offshore coastal environments. Contacts with underlying cross-bedded microphytolitic dolarenites and enclosing micrites and dolarenites are sharp. Basal portions of the lithostromes consist of highly branched cylindrical columns showing low to moderate inheritance. The columns are $2-8 \mathrm{~cm}$ in diameter and lobate in cross-sectional view. Laminae are smooth and steeply convex, developing synoptic relief up to $8 \mathrm{~cm}$. In

FIGURE 5-Microfossils in the subtidal (lagoonal) carbonate facies. 1, low power photomicrograph of thin section, showing abundant silicified internal molds of vertical tubes in dolomicrite; upper (light) portion is chert; 2,6 , higher magnification views of facies illustrated in 1; in 2 (P. 13, G24/0, HUHPC \#62363), note branching at arrow; in 6 (P-13-3A, M7/3, HUHPC \#62364), the ovoid chert bodies are oblique sections through silicified internal molds of vase-shaped microfossils. 3, SEM of a silica filament internal mold showing branching and the imprint of dolomite euhedra on its surface; 4, 5, low power thin-section views of lagoonal facies showing the distribution of Trachyhystrichosphaera acritarchs, silica internal molds of vase-shaped microfossils, and organic debris; 4 is a chert nodule; in 5 , a silicification front runs through the section, with dolomite (but with silica-filled VSM's and silica micronodules nucleated on organic debris) to the left and chert to the right. Bar in $5=800 \mu \mathrm{m}$ in 1,4 , and $5 ;=200 \mu \mathrm{m}$ in 2 and 6 ; and $=50 \mu \mathrm{m}$ in 3 . 


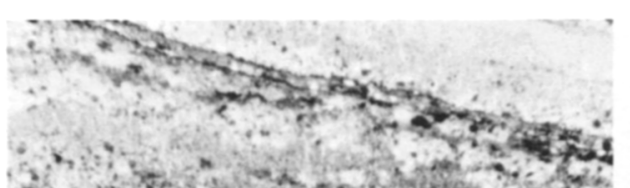

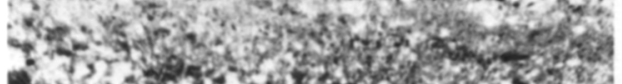

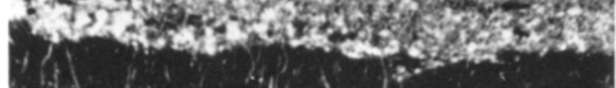

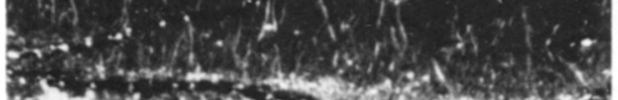

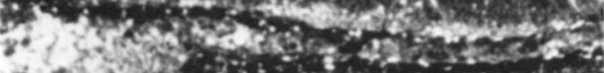

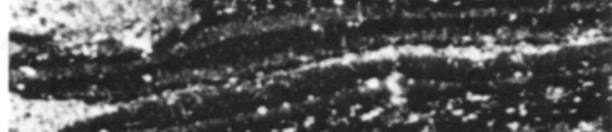

4.

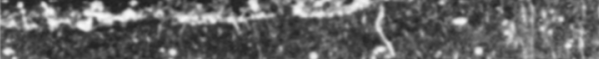

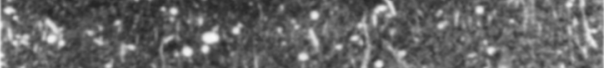

1.27 .2 grate

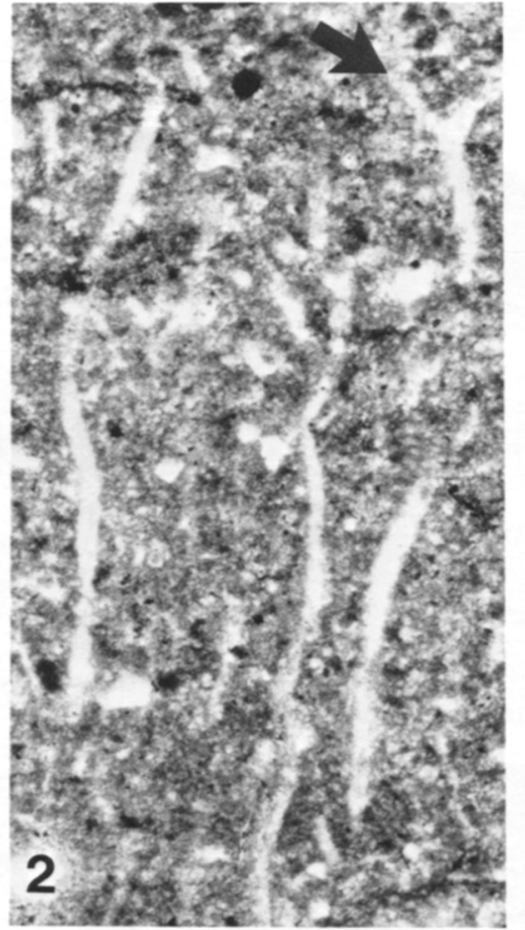

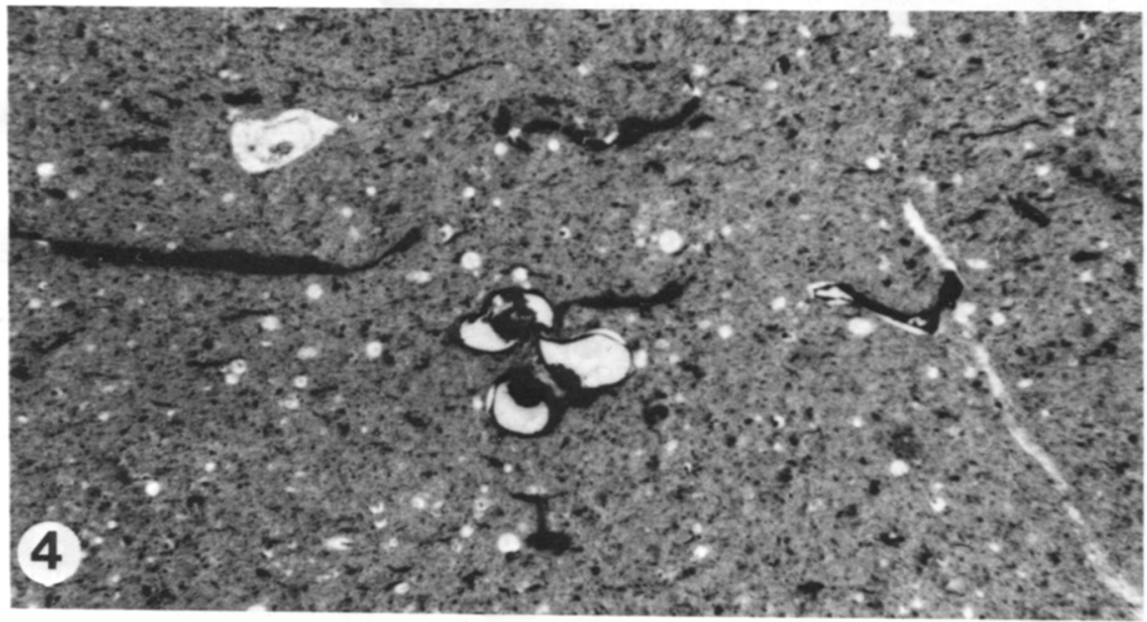

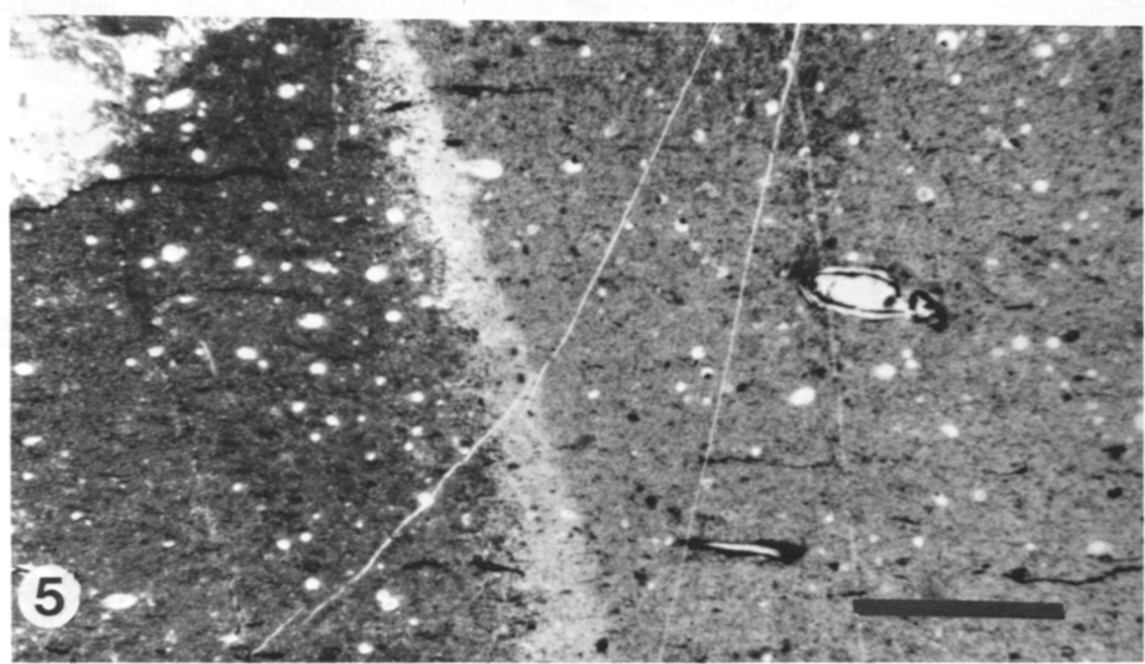

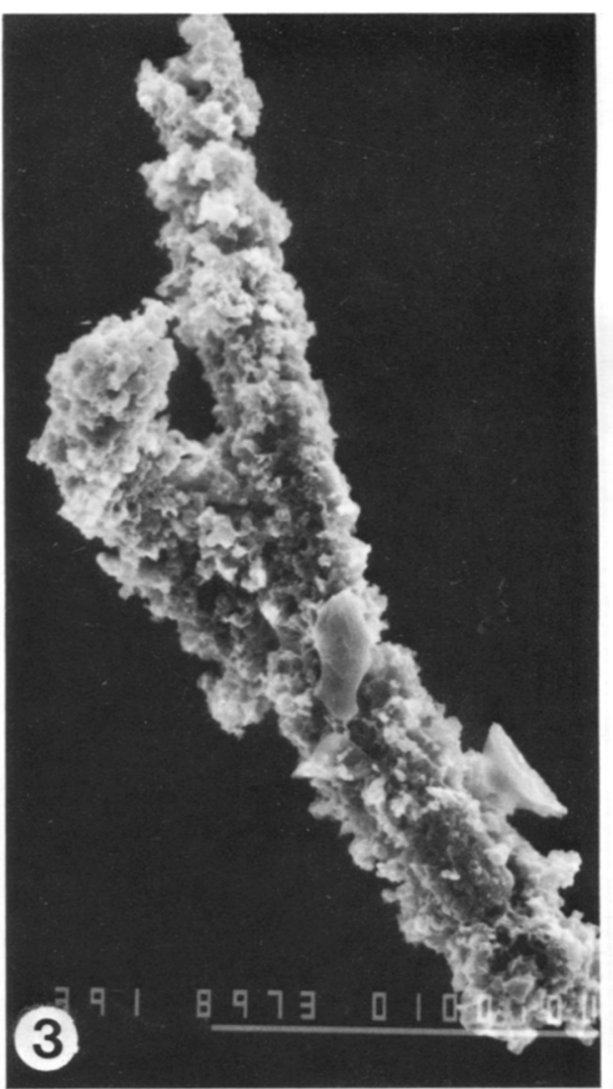

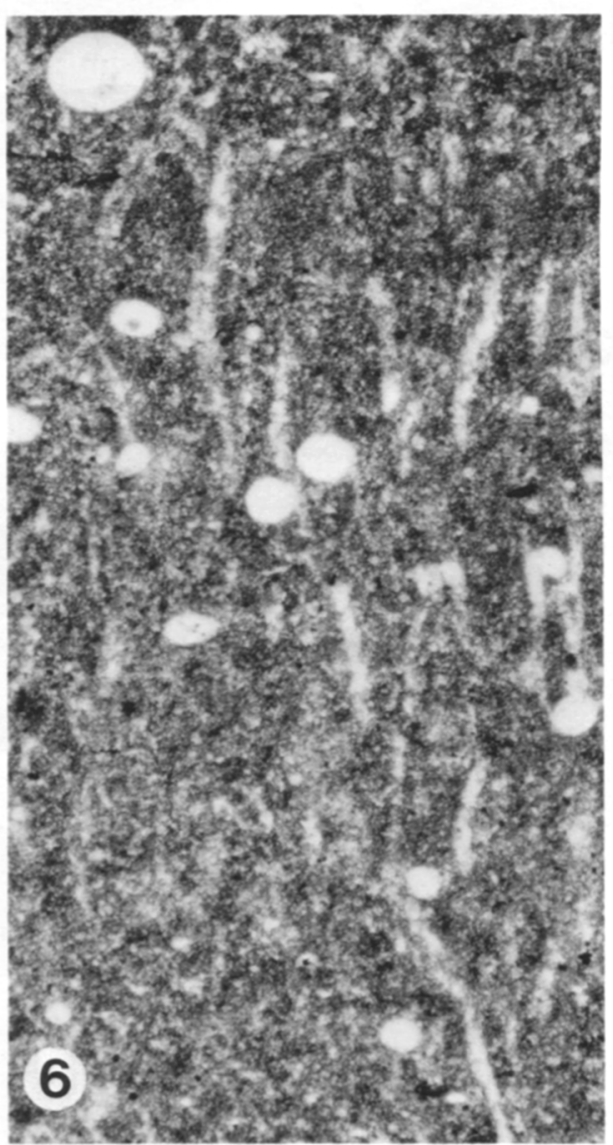



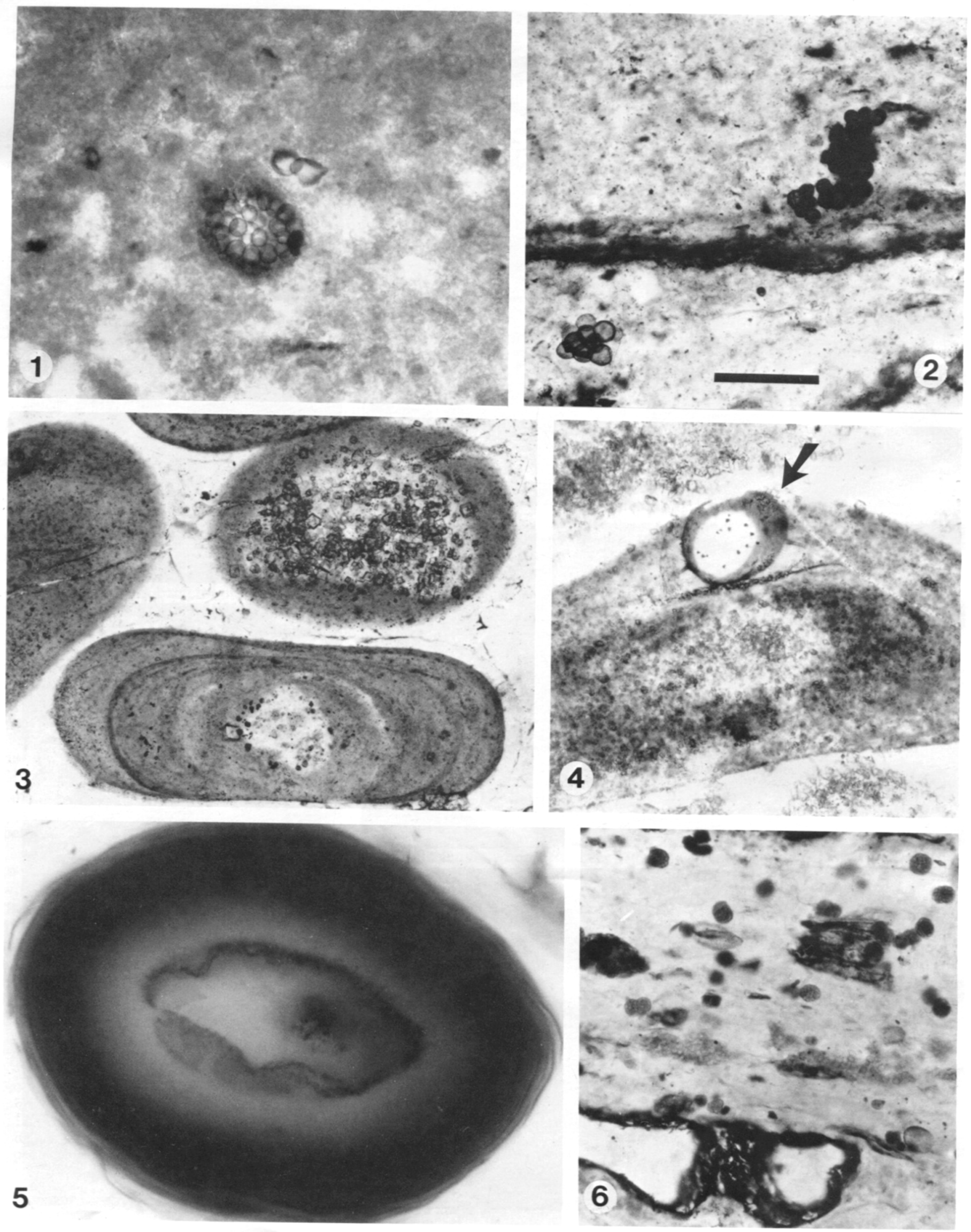
TABLE 4-Taxa present in lagoonal silicified carbonate assemblage [samples P-245, P-13 (partim), P-17, P-92, P-96, P-4350, P-4420, and M-31].

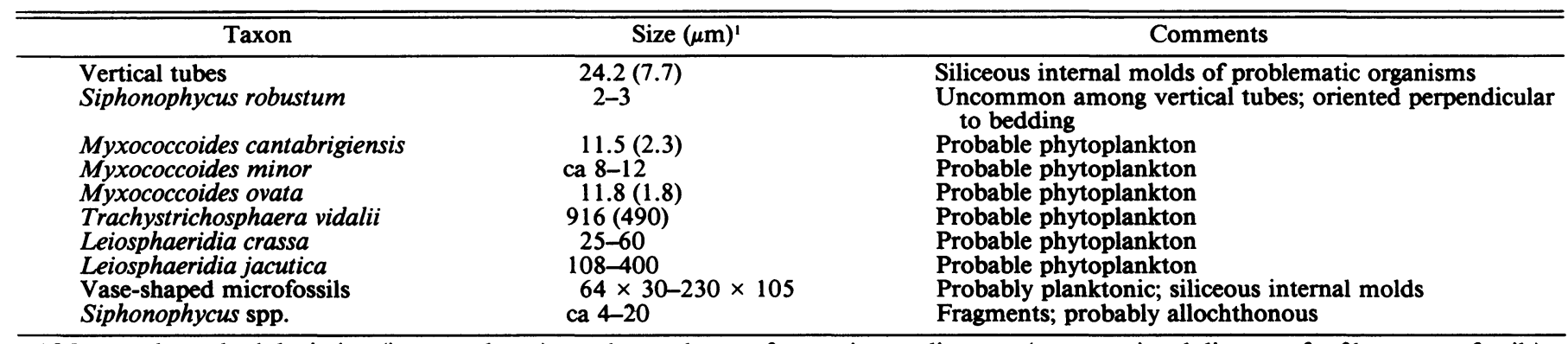

' Mean and standard deviation (in parentheses), or observed range for maximum diameter (cross-sectional diameter for filamentous fossils).

upper portions of the lithoherms, columns are more regularly cylindrical, parallel, and sparsely branched (Figure 20.2). Intercolumnar sediments include fine-grained carbonates, microphytolites, and stromatolitic intraclasts.

In thin section, laminar fabrics are porostromate; they consist of interwoven dolomitic filaments (Figure 20.3-20.5; Pia, 1927). Filaments are 2-6 $\mu \mathrm{m}$ in diameter, unbranched, and oriented roughly parallel to lamination. Because of their small size, it is often difficult to determine whether filaments are hollow or solid, but scattered, clearly hollow specimens have walls defined by a thin rind of tiny dolomite crystals surrounded by radiating acicular dolomite euhedra up to $5 \mu \mathrm{m}$ long. These acicular crystals give the visual impression of a diffuse boundary. Filaments float in a matrix of interlocking 1-25 $\mu \mathrm{m}$ dolomite euhedra. Irregular porostromate laminae $100-500$ (rarely 700) $\mu \mathrm{m}$ thick are separated by subequal thicknesses of filament-free dolomite microspar. Quartz sand grains and the carbonate molds of vaseshaped microfossils are minor components of both porostromate and filament-free laminae.

The Draken filaments are unusual in two respects. Mat-building populations are seldom preserved in Proterozoic columnar stromatolites, and (?)cyanobacterial calcification is uncommon in carbonates older than late Vendian or Cambrian. Microfossils have been reported from silicified columnar stromatolites, and where mat-building populations can be identified, they are often sheath-forming oscillatorian cyanobacteria similar in general morphology to the Draken filaments (e.g., Licari, 1978; Sergeev, 1984). Oscillatorians are also important components of microbial communities that build subtidal columnar stromatolites today on the Bahama Banks (Dill et al., 1986). The Draken and other columnar stromatolitic fossils are significant insofar as they show that models of stromatolite growth based predominantly on modern flat-laminated mats and ancient stratiform stromatolites apply to a morphologically broad range of stromatolite types (Swett and Knoll, 1985); however, taphonomic information loss precludes detailed biological comparisons.

Girvanella and other calcified microorganisms are well known from Phanerozoic carbonates (e.g., Johnson, 1961; Wray, 1977), but as noted above, comparable preservation is uncommon in Proterozoic rocks. Indeed, calcified (?)cyanobacteria are often assumed to be absent from pre-Phanerozoic rocks, and this has been used to infer significant changes in ocean chemistry near the Proterozoic-Cambrian boundary (e.g., Riding, 1982). How- ever, not only do calcified filaments occur in Draken stromatolites, this occurrence is not unique. Aitken (1989) has described carbonate-lined structures from stromatolites that form pinnacle reefs in basinal facies of the Neoproterozoic Little Dal Group, Canada, and calcitized filaments also occur in Upper Riphean columnar stromatolites from the Yenisey Ridge, U.S.S.R. (Komar, 1979). The origin of the Draken calcified fossils is uncertain, but their presence indicates that under the right conditions, the calcification of microorganisms was possible long before the dawn of the Cambrian Period.

In fact, the Girvanella-like tubes are not the only calcified fossils in the Draken Formation. One sample from the Polarisbreen region contains thin horizons of closely packed cylindrical tubes oriented perpendicular to bedding (Figure 12.8). The tubes range from 40 to $170 \mu \mathrm{m}$ in diameter, and can reach lengths of $2 \mathrm{~mm}$. Most appear unbranched but one convincing dichotomy was observed. Tube walls are defined by a dark rim of minute dolomite crystals. Inter-tube dolomite is also finely crystalline, while intra-tube dolomite forms a coarse mosaic.

Despite differences in preservational mode, these dolomitic fossils can be compared with encrusting populations of Polybessurus bipartitus described from partly correlative beds in East Greenland (Green et al., 1987; compare their fig. 5) and South Australia (Fairchild, 1975). Similarities include general morphology and encrusting habit. Calcified Draken populations do not display the chevron-like stacking of envelopes seen in silicified $P$. bipartitus, but this is explained easily as a taphonomic difference; the "stalks" of large Polybessurus specimens in the East Greenland crusts are frequently degraded to hollow tubes and may be filled by diagenetic carbonate. The Greenland and Draken crusts are further similar in their common inclusion of Siphonophycus inornatum sheaths aligned more or less parallel to Polybessurus "stalks." Draken crusts occur in highly fenestrate grainstones, but clasts appear to have been excluded from crust horizons.

Shale assemblage. - Carbonaceous shale and siltstone occur sporadically throughout the Draken Formation as partings to thin beds (generally less than $25 \mathrm{~cm}$ thick). Few of these units are fossiliferous, but sample P-23, collected from a thin shale exposed in the Polarisbreen area, contains abundant and moderately well-preserved organic-walled fossils. The shale is one of a population of partings to thin beds intercalated among a complex interleaving of 10-20-cm-thick cross-bedded dolar- 

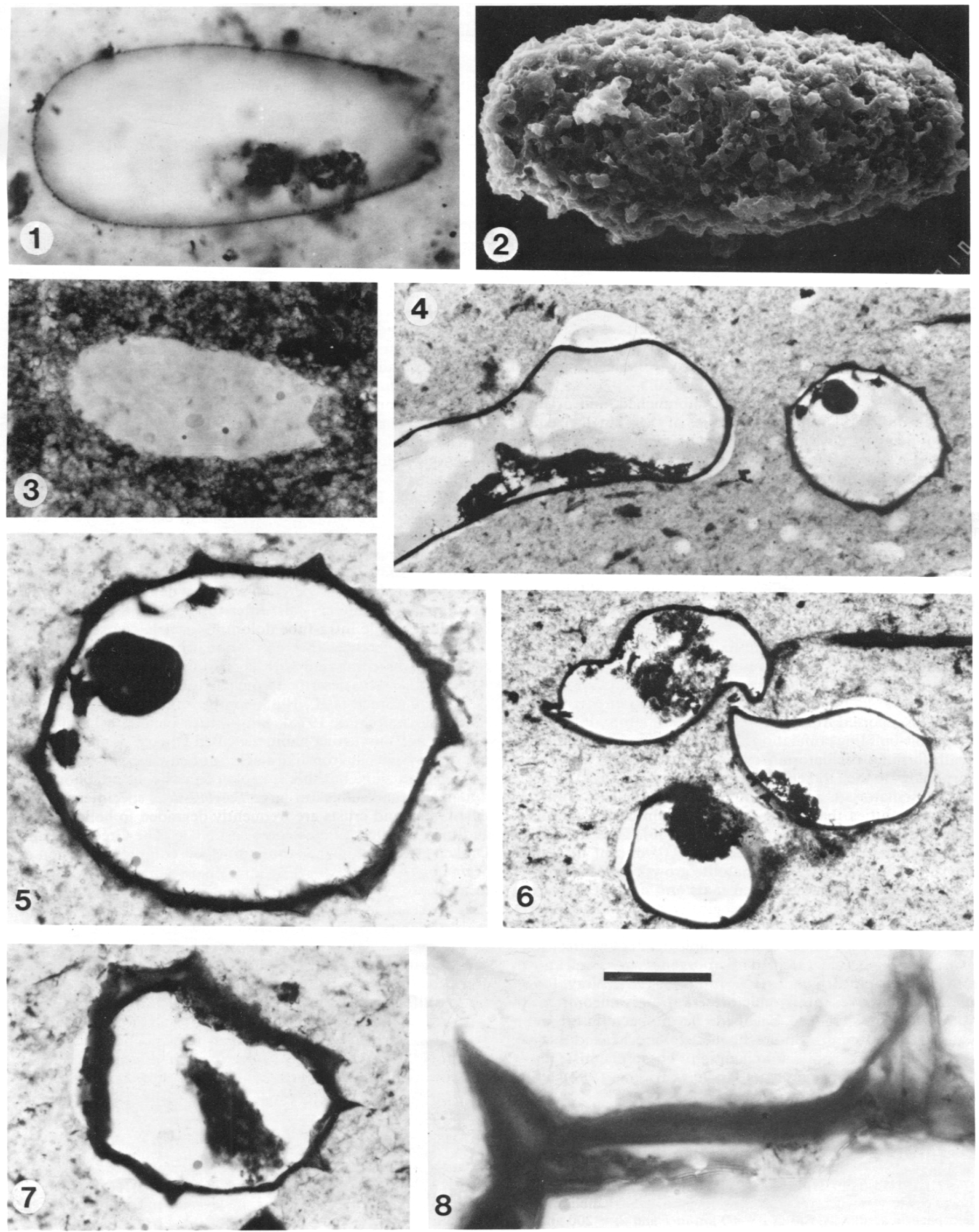
enites, stratiform stromatolites, and subtidal dolomicrites and carbonaceous micrites. The fossiliferous shale is interpreted as a coastal subtidal deposit, an interpretation supported by its fossil content.

In general, the fossils preserved within sample P-23 can be compared with those found in previously discussed carbonate lithologies (Table 7). Small (9-25 $\mu \mathrm{m})$, relatively thick-walled spheroidal vesicles are the most abundant constituent of this assemblage, making up 50 percent of all identifiable remains. These fossils occur as isolated individuals or, rarely, in clusters of up to 10-20; they cannot be differentiated from Myxococcoides cantabrigiensis populations preserved in Draken subtidal to lower intertidal cherts. About 10 percent of the assemblage consists of filamentous sheaths ranging from 2 to $20 \mu \mathrm{m}$ in crosssectional diameter (Figure 21.7). Essentially all of these remains are fragmental and, hence, most likely allochthonous. The observed size range compares closely with that established for tidal-flat mat-builder populations, and it is thus reasonable to assume that many of these sheaths originated with tidal-flat cyanobacteria. Trichome remains (Figure 21.8-21.10) are nearly as common as sheaths in sample $\mathrm{P}-23$, in line with previous work suggesting that preservation in siliciclastic lithologies can equal or exceed that generally attributed to cherts (e.g., Jankauskas, 1982; Butterfield et al., 1988; Butterfield, 1990). Like the sheaths, trichome remains are generally fragmental and 2$19 \mu \mathrm{m}$ in cross-sectional diameter. Trichomes, of course, provide morphological data on cell length and morphology as well as width, and Draken shale filaments suggest a species diversity higher than that discernible in silicified tidal-flat populations or shale fragments. A final component possibly derived from adjacent tidal flats consists of rare ( 1 percent of the assemblage) prokaryotes otherwise found in tidal-fiat mats, such as Gloeodiniopsis mikros (Figure 21.11).

The remaining third of the shale assemblage consists of acritarchs. Thin-walled spheroidal vesicles comparable to Stictosphaeridium spp. (sensu Vidal, 1976) are relatively common, as are more robust spheroids in the $30-70 \mu \mathrm{m}$ range, assignable to Leiosphaeridia crassa (Figure 21.4, 21.5). Individual vesicles display some variation in wall texture, but much if not most of this variation appears to be diagenetic in origin (Figure 21.6). Large leiosphaerids (Leiosphaeridia jacutica and Leiosphaeridia sp. cf. L. atava) commonly occur as fragmental remains, although whole vesicles can be recovered (Figure 21.1-21.3). Morphologically comparable acritarchs are common in coastal marine facies of Neoproterozoic age (e.g., Vidal, 1976; Jankauskas, 1982, 1989; Knoll, 1984). Rare incomplete specimens of Trachyhystrichosphaera vidalii, Gorgonisphaeridium maximum comb. nov. (Figure 21.12), and Satka sp. round out the assemblage.

Oncolitic assemblage. - Thin oncolite beds occur sporadically in the middle and upper thirds of the Draken succession. Sedimentologically and paleontologically, grains in the Draken oncolites are very similar to the minute fossiliferous oncoids described from the overlying Backlundtoppen Formation (Knoll et al., 1989); thus, only brief mention is made here. The oncoids are ellipsoidal structures up to approximately one millimeter long (Figure 6.3). Crescentic laminae generally contain only amorphous organic matter, but in samples P-4665, P-28, and

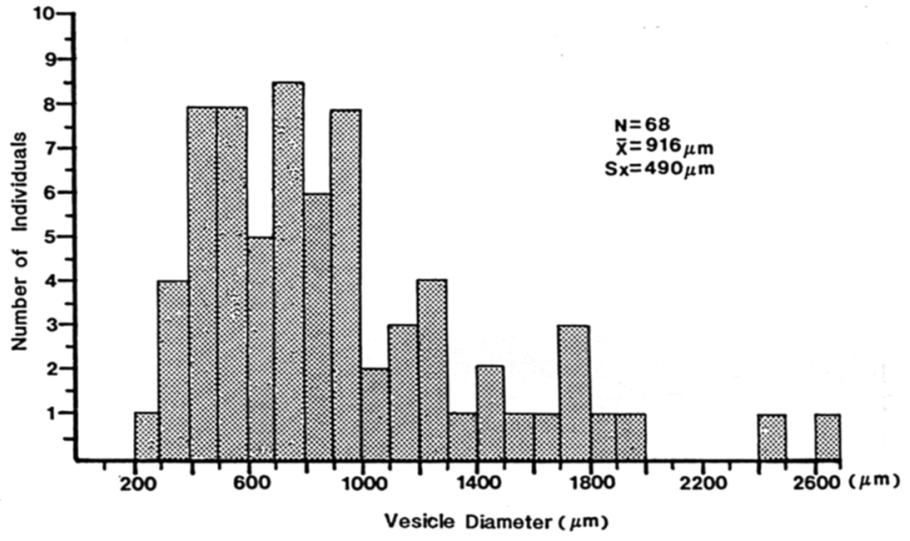

FIGURE 8-Size frequency distribution of a sample population of Trachyhystrichosphaera vidalii from the subtidal (lagoonal) carbonate facies.

P-97 a few grains preserve densely interwoven sheaths of $\mathrm{Si}$ phonophycus robustum, the presumably oscillatorian oncoidand mat-builder. These oncoids appear to have accreted in shallow water on the flanks of protecting shoals, an interpretation corroborated by the incorporation of Trachyhystrichosphaera vidalii into the laminae of one grain (Table 8; Figure 6.4).

\section{PALEOENVIRONMENTAL SYNTHESIS}

The paleoenvironmental distribution of Draken microfossils. Along present-day coast lines, the environmental distributions of bacterial and protistan populations are often sharply delimited (e.g., Round, 1981). Realized habitat ranges are generally narrower than those circumscribed by physiological tolerances, strongly suggesting that organism-organism interactions such as competition and predation play an important role in determining population distributions (e.g., Knoll and Bauld, 1989). One might expect that Proterozoic microorganisms would also be distributed along environmental gradients, and indeed the common paleontological observation is that populations are strongly facies dependent (e.g., Hofmann, 1976; Knoll, 1981; Green et al., 1989). The Draken Conglomerate Formation clearly contains a number of distinct microfossil biofacies. Those in in situ rocks-stratiform stromatolites and lagoonal micrites-are easily mapped onto the supratidal-subtidal gradient, but associations confined to redeposited clasts present an interpretational challenge. Fortunately, the ranges of many individual species extend across several associations, so that the simple assumption of range contiguity permits an unambiguous paleoenvironmental ordering of biofacies. The five principal biofacies recognized in Draken rocks are shown in Table 9 and Figure 22 , and the distributions of individual species among biofacies are shown in Figure 23. Of the eight taxa of benthic filaments recognized, seven have clearly defined distributions that can be used to define and link assemblages. Siphonophycus kestron mats fall at the upper end of the exposure scale, while vertical, branched filaments characterize submerged lagoonal muds. Mats dominated by Siphonophycus inornatum (thick and thin walled) and $S$. septatum are intermediate, and are ordered on the basis

FIGURE 7-Microfossils from the subtidal (lagoonal) carbonate facies. 1-3, vase-shaped microfossils preserved as organic vesicles in chert (1, M-31-1A, L23/0, HUHPC \#62369) and as silica-filled internal molds in dolomite (2, SEM showing impressions of dolomite euhedra; 3, P-13, K15/0, HUHPC \#62370); 4-8, Trachyhystrichosphaera vidalii (4 and 5, P-245-1B(5), U27/3, HUHPC \#62371; 6, P-245-1B(1), O18/1, HUHPC $\# 62372 ; 7, \mathrm{P}-245-1 \mathrm{~B}(3), \mathrm{M} 19 / 4$, HUHPC \#62372; 8 , a detail of 7 showing process structure. Bar in $8=25 \mu \mathrm{m}$ in 1 and $2 ;=50 \mu \mathrm{m}$ in $3 ;=$ $200 \mu \mathrm{m}$ in 4 and $6 ;=150 \mu \mathrm{m}$ in $7 ;$ and $=20 \mu \mathrm{m}$ in 8 . 
of the distributions of $S$. capitaneum and $S$. robustum. All other populations can be mapped onto this framework; resulting ranges are continuous and trends in morphology and/or abundance are predictable or at least logical. Thus, of the 42 taxa recognized in Draken rocks, 39 have paleoenvironmental distributions that can be characterized in detail. Those of the three remaining species can be constrained to within a portion of the gradient, but because the fossils are isolated in individual clasts, their precise distributions remain somewhat ambiguous.

While these paleoenvironmental interpretations are derived primarily on the basis of empirical paleontological considerations, they are supported by independent petrological microfacies analysis (Fairchild et al., in press). They also make sense in light of microbial distributions along modern tidal flats. For example, several distinct trends are evident along the Draken supratidal to subtidal gradient (Figure 24). Extracellular sheaths of mat-building cyanobacteria are commonly thick in the most frequently exposed assemblages, thinning markedly toward permanently submerged lagoons. As noted above, a similar trend is seen in modern systems and appears to reflect the important role of sheaths in cyanobacterial tolerance to desiccation and high fluxes of solar radiation. At the same time, the diversity of both mat-dwelling microbenthos and allochthonous fossils increases along the same gradient, much as it does in modern mat communities, where diversity is inversely proportional to environmental stress (Golubic, 1976; Whitton and Potts, 1982). Microbenthic diversity appears to decrease in the lagoons, but this may be misleading in that permanently submerged microorganisms often lack robust sheaths and/or cysts that facilitate preservation (Golubic and Barghoorn, 1977). Plankton/allochthon diversity is clearly highest in lagoonal muds; although plankton-bearing sea water regularly flooded the tidal flats, many populations were able to avoid becoming marooned on mat surfaces.

A final trend evident in thin sections is that the ratio of sediment to fossils in a given volume of rock increases markedly from upper intertidal or supratidal mats across the tidal flat to the lagoons.

Broader paleoecological considerations. - The environmental range of the Akademikerbreen Group exceeds that recorded in the Draken Conglomerate Formation, as does its paleontological diversity. The tidal flat/lagoonal environments of the Draken Formation can be related sedimentologically to oolitic shoals and more open coastal-marine environments represented elsewhere in the group (Knoll and Swett, 1990). Fossil assemblages have been recorded for much of this range. Endolithic, epilithic, and interstitial populations from oolitic shoals are well displayed in the Backlundtoppen Formation and its equivalents in East
Greenland, and oncoid-building and mat-forming cyanobacteria that apparently lived on the flanks of shoals occur as well (Green et al., 1988; Knoll et al., 1989). Both tidal flat and opencoastal assemblages occur in the Svanbergfjellet Formation (Butterfield et al., 1988). The overall pattern is a series of microbial-mat communities deployed along extensive tidal flats; a lagoonal biota characterized by both distinct microbenthos and plankton; oncoids and thin mats built along shoal margins by Siphonophycus robustum, an auxiliary builder in some marginal intertidal/subtidal $S$. septatum mats; an oolitic assemblage consisting of 8-10 distinct endolithic cyanobacterial populations, accompanied by several cyanobacterial and protistan epiliths and interstitial space dwellers; and a quiet offshore biota containing diverse prokaryotic microbenthos, seaweeds, and diverse phytoplankton. Microbial mats formed in these offshore environments and locally built up into stromatolitic patch reefs. Within individual biofacies, species diversity may vary from one or two species to $\mathbf{3 0}$ or more. As many as $\mathbf{8 0}$ morphologically distinguishable taxa occur in the group as a whole, and no one species occurs in all facies. Neither does any one facies represent Akademikerbreen diversity as a whole, although the quiet subtidal mudstones display the greatest variety of forms (Butterfield et al., 1988).

Just as no one facies characterizes overall Akademikerbreen biology, neither do Akademikerbreen fossils exhaust the diversity of the late Riphean fossil record. Extensive data from the Soviet Union corroborate many features of Akademikerbreen paleontology, but the Soviet record contains both environments and taxa not represented in Spitsbergen (summarized in Jankauskas, 1989). Other extensions include Eoentophysalis mats and associated assemblages from arid-zone tidal flats (represented in the Neoproterozoic by the Narssârssuk Formation, Greenland; Strother et al., 1983), the ecologically heterogeneous and locally diverse coastal playa-lake biotas of the Bitter Springs Formation, Australia (Schopf, 1968; Schopf and Blacic, 1971; Knoll and Golubic, 1979; Knoll, 1981; Southgate, 1986), and even assemblages of small phytoplankton from deep-water turbidites such as the lower Hedmark Group, Norway (Vidal and Nystuen, 1990).

\section{CONCLUSIONS}

Neoproterozoic oceans were diverse and ecologically heterogeneous, but not randomly so. Patterns of diversity and species distribution among environments can be resolved using approaches and gaining insights comparable to those routinely associated with Phanerozoic fossils. Moreover, many of these patterns can be interpreted in light of Recent sedimentological and biological analogs. For the first time, we are coming to

FIGURE 9-1,2, outcrop views of lower flake conglomerate facies; chert nodules and silicified clasts are black. 3, thin-section view of lower flake conglomerate, showing compacted dolomite grains (dark) and relatively uncompacted grains in silicified area (light); ghosts of vertical tubes are faintly visible in the large silicified clast at the top of the picture; 4, 5, Siphonophycus inornatum mats in lower flake conglomerate clasts (4, P-4353-7G, G20/0, HUHPC \#62373; 5, P-4353-1A, R21/1, HUHPC \#62374); 6, S. inornatum mat in which filaments are preserved as iron-oxide infillings. Ruler in 1 is $15 \mathrm{~mm}$; bar in $4=25 \mathrm{~mm}$ for $2,=1.5 \mathrm{~mm}$ in 3 , and $=100 \mu \mathrm{m}$ in $4-6$.

FigURE 10-Lower flake conglomerate assemblage. 1, low magnification view of Siphonophycus septatum mat containing Myxococcoides; 2 , S. septatum mat population (P-4353-13A, T19/1, HUHPC \#62375); 3, 5, S. robustum differentially well preserved in $S$. septatum mats (3, P-91, U22/4, HUHPC \#62376; 5, W(P)-839-B, V31/3, HUHPC \#60475); 4, 6, Salome svalbardensis filaments in $S$. septatum mat clasts, note the absence of diffluent outer sheaths in 6 (see Knoll, 1982) (4, W(P)-837-D, K23/2, HUHPC \#60483; 6, W839-D, L26/0, HUHPC \#60487); 7, large Myxococioides cantabrigiensis population in clast (P-4353-12F, F19/3, HUHPC \#62377); 8, Myxococcoides minor (W(P)-837-B, L8/4, HUHPC \#60511). Bar in $5=50 \mu \mathrm{m}$ in 1,2 , and $3 ;=35 \mu \mathrm{m}$ in 4 and $6 ;=20 \mu \mathrm{m}$ in $5 ;=200 \mu \mathrm{m}$ in 7 ; and $=15 \mu \mathrm{m}$ in 8 .

FIGURE 11-Myxococcoides cantabrigiensis in the lower flake conglomerate facies. 1, 5, low magnification views of populations; 2, 4, details of individual vesicles (P-4353-7G, G21/0, HUHPC \#62378); 3, cluster of vesicles within a split larger vesicle (P-91-1A, R20/4, HUHPC \#62379); 6 , cluster showing variable preservation of internal contents (M-13-8A, V22/4, HUHPC \#62380). Bar in $4=60 \mu \mathrm{m}$ in 1 ; = 12 $\mu \mathrm{m}$ in $2-4$ and 6 ; and $=200 \mu \mathrm{m}$ in 5 . 

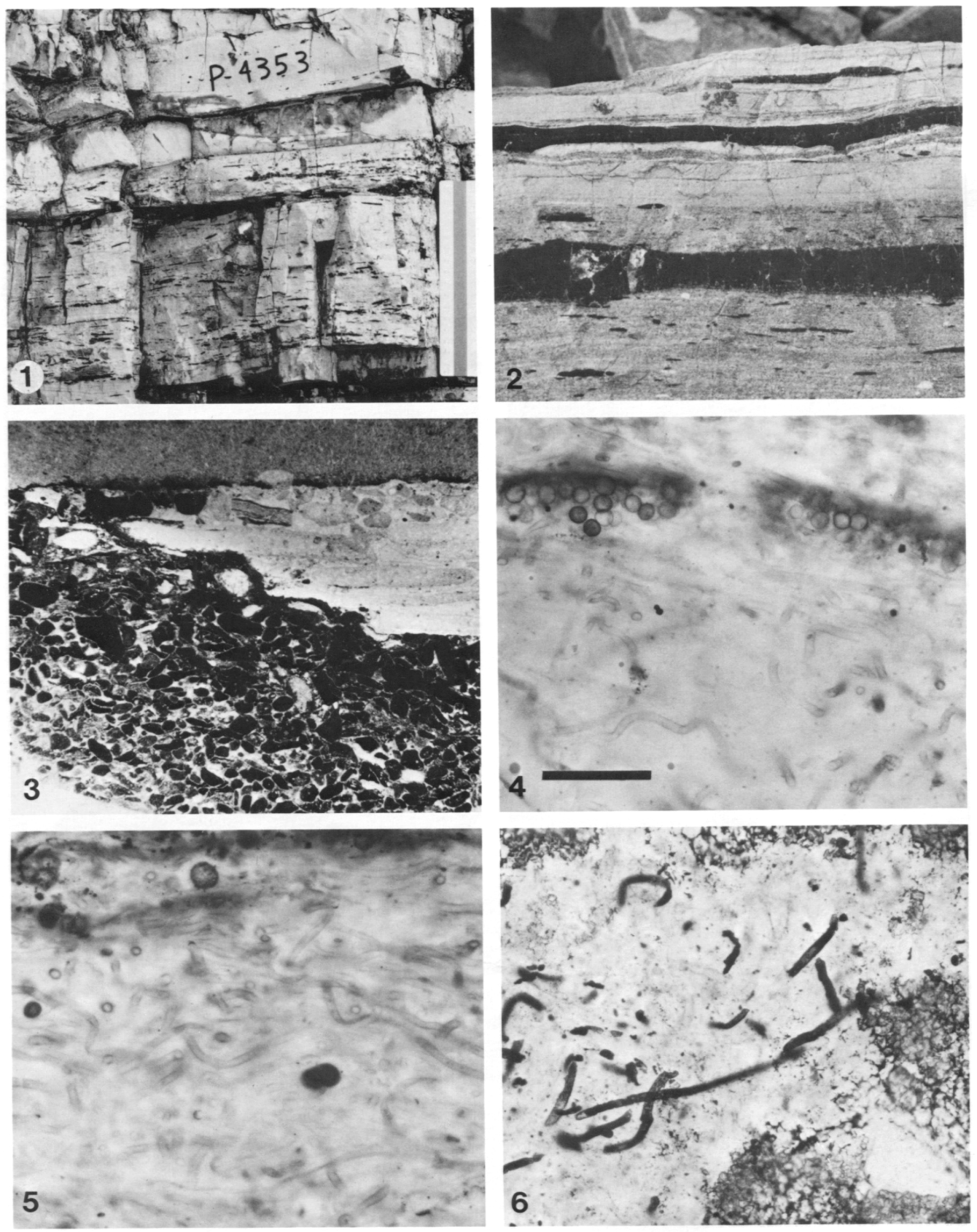

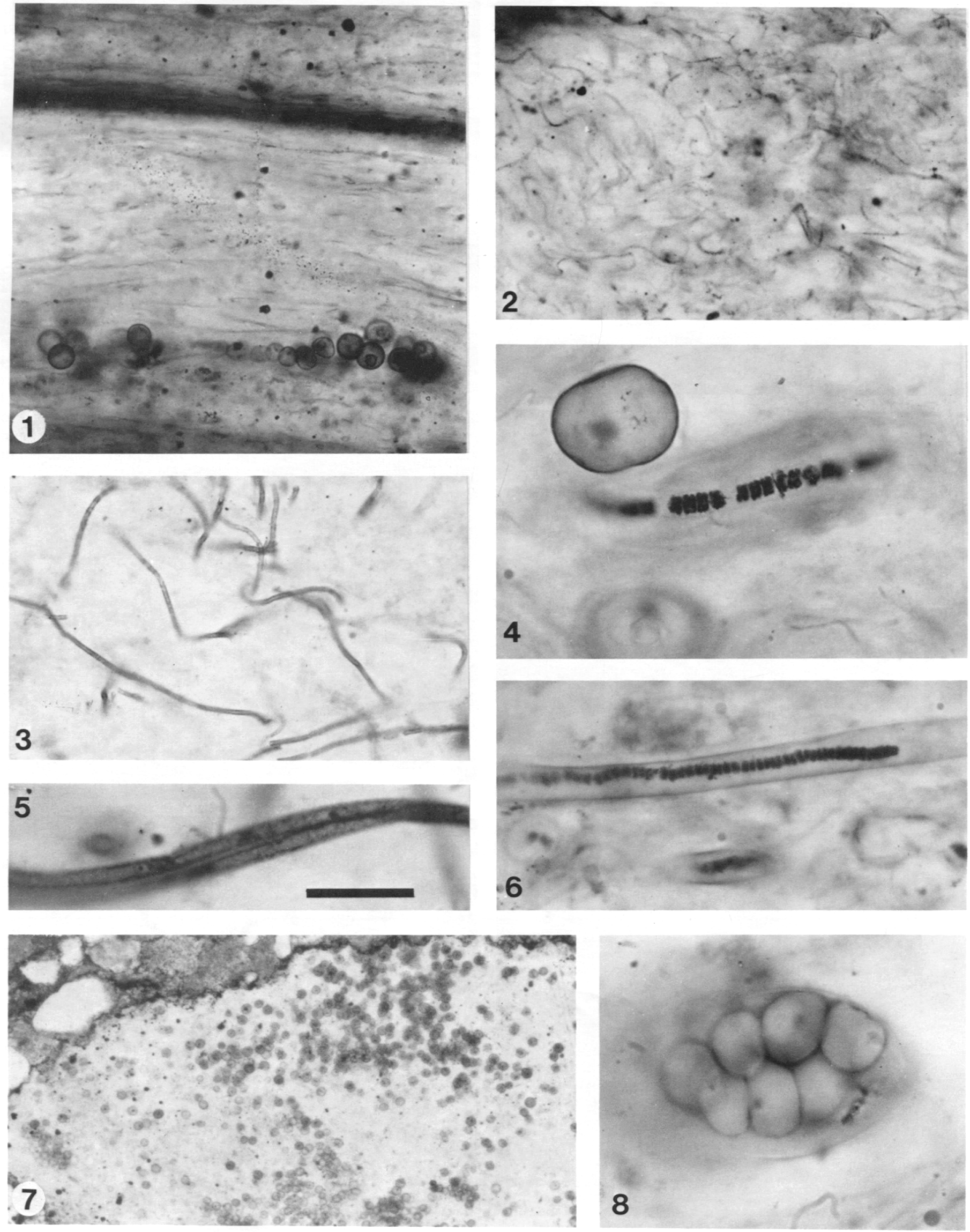

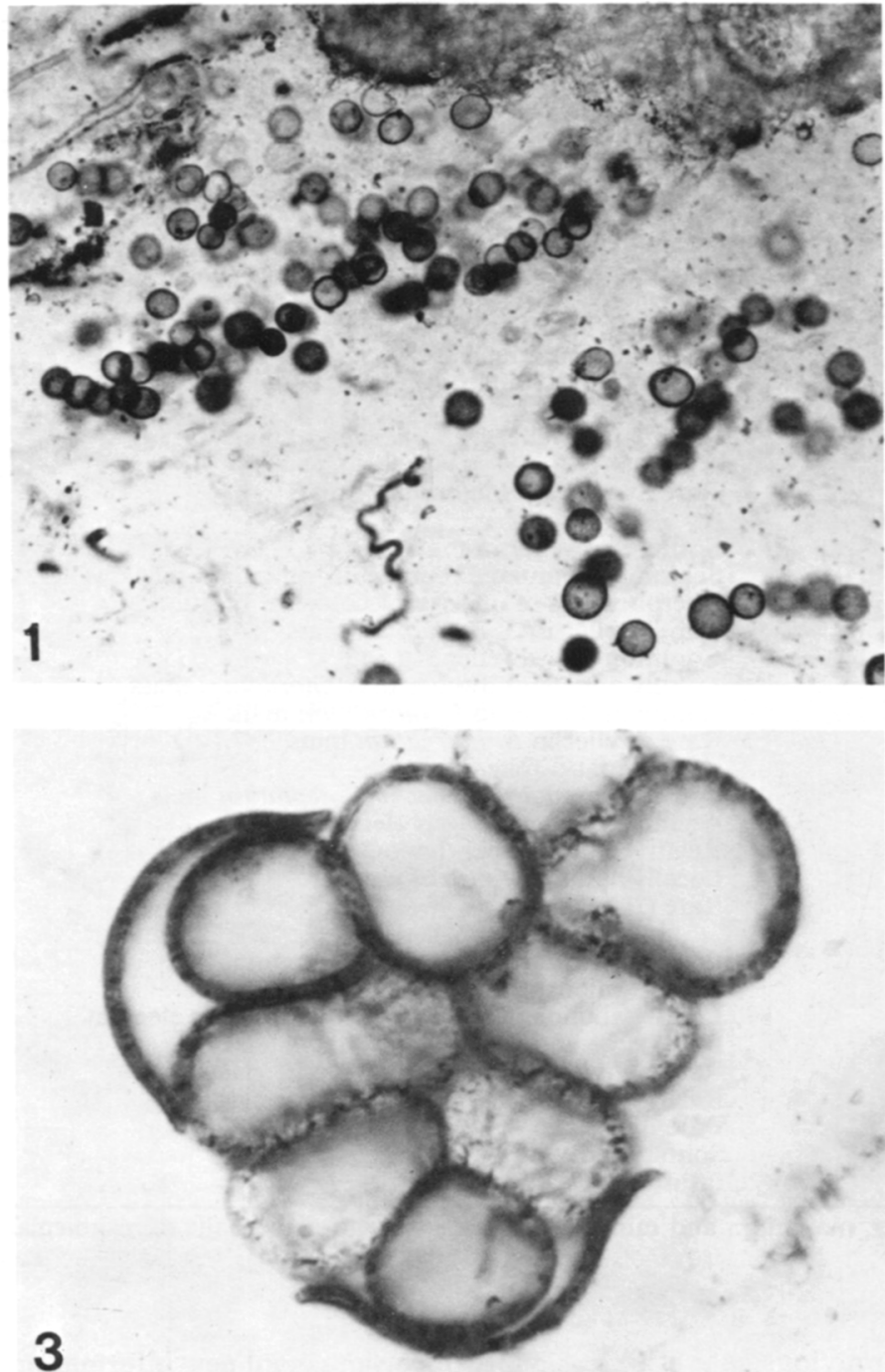

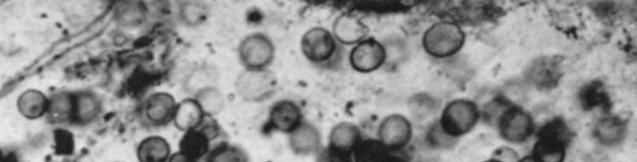

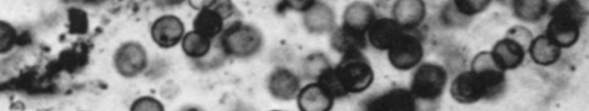
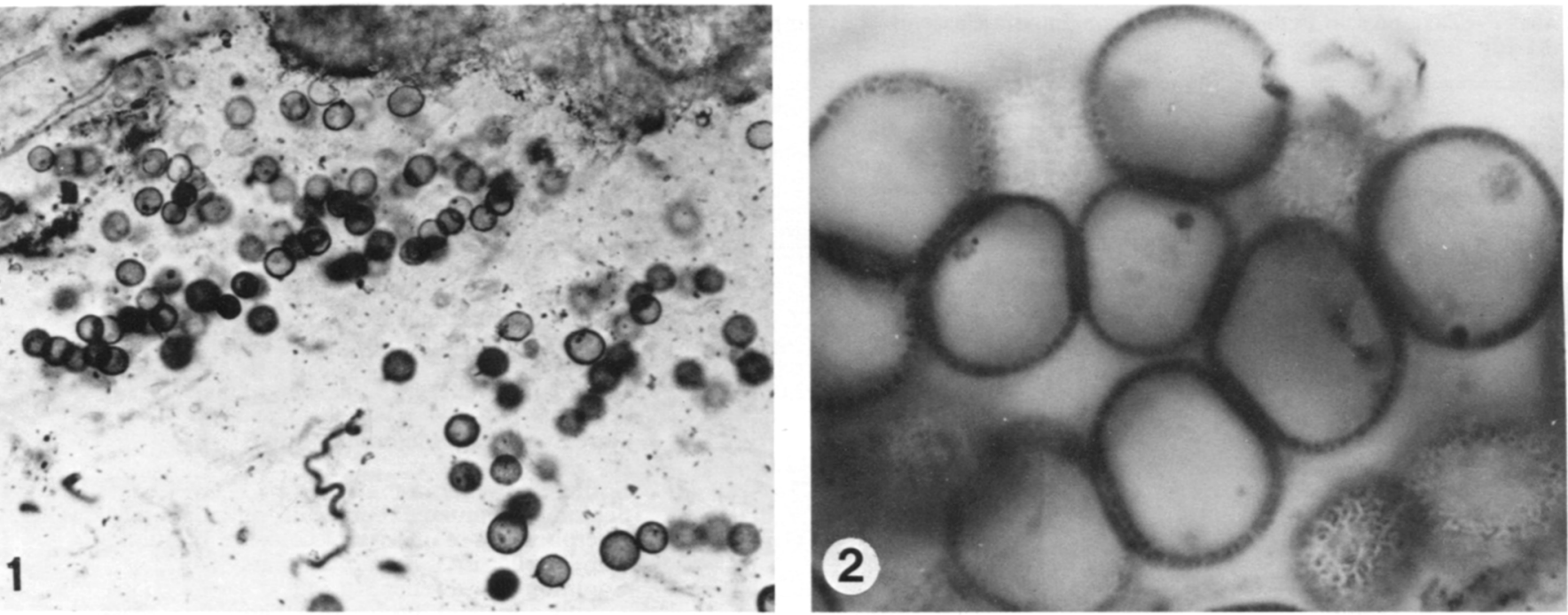

3
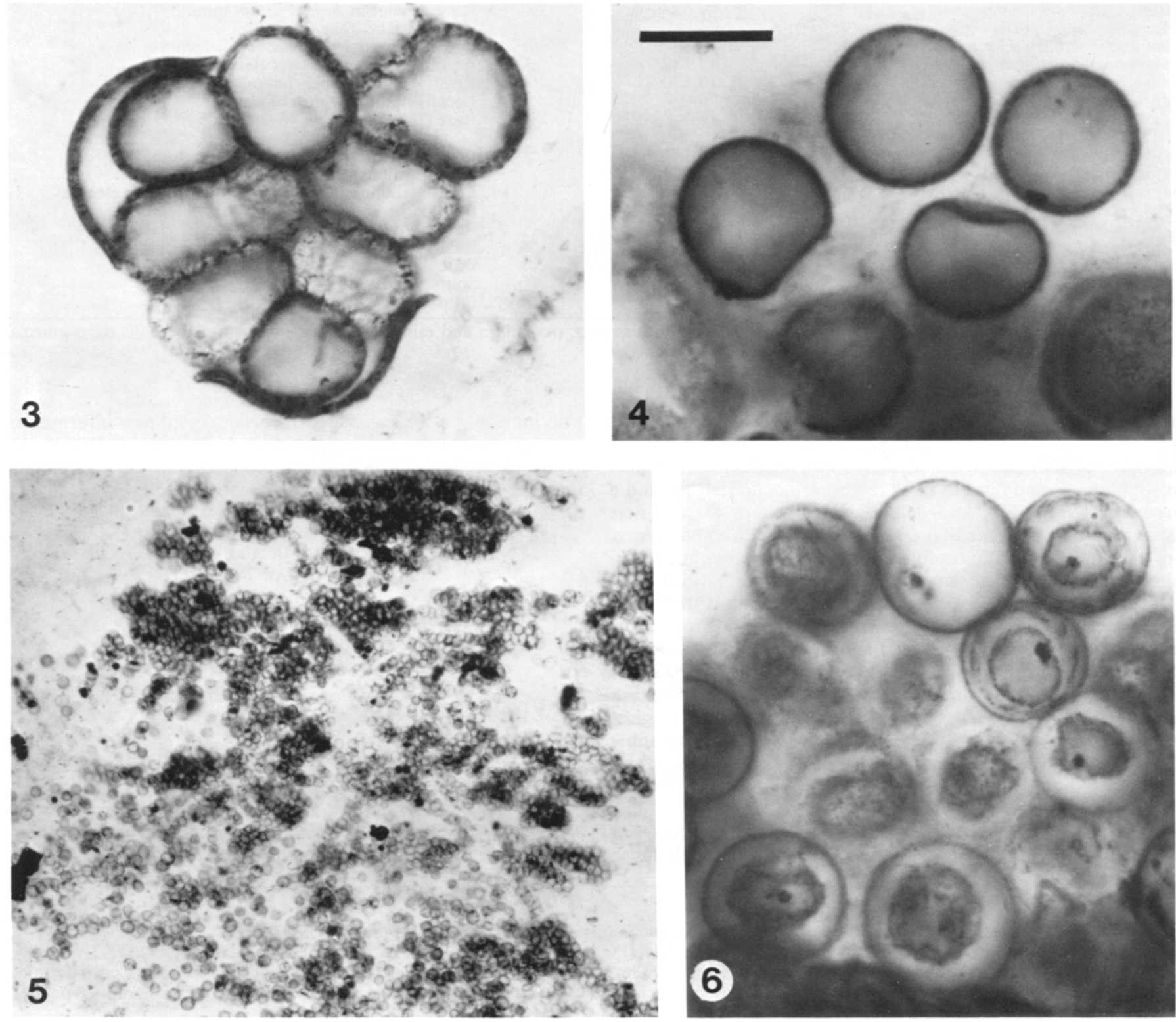
TABLE 5-Taxa present in the lower flake conglomerate assemblage (samples P-13, P-91, P-4340, P-4420, B-165, SP-15, M-11, M-12, M-13, and M-28).

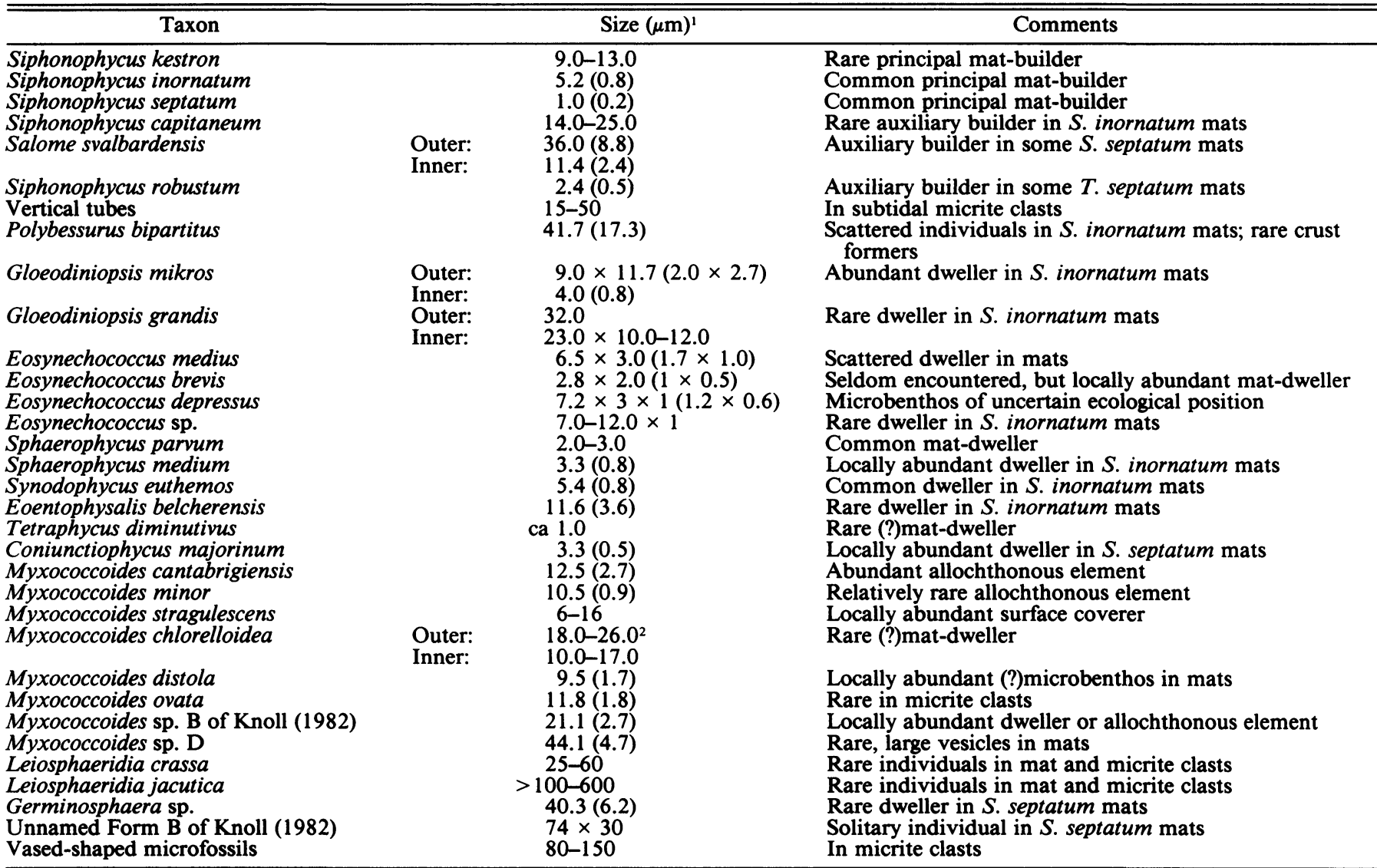

${ }^{1}$ Mean and standard deviation (in parentheses) for maximum diameter, maximum and minimum dimensions, three mutually perpendicular dimensions, or, for filamentous fossils, cross-sectional diameter.

${ }^{2}$ See Figure 14 for additional data.

understand how organisms were distributed in Proterozoic oceans, and this has significant implications for studies of both stratigraphy and evolution. Proterozoic microfossils are now available as tools to aid in paleoenvironmental analysis, and a firmer paleoecological knowledge will permit us to recognize those temporal patterns that truly reflect evolution and, hence, are biostratigraphically useful. There can be no confidence in biostratigraphic zonations or evolutionary interpretations without a knowledge of how different paleoenvironments were populated (and sampled) at different time intervals. In Proterozoic paleontology, the primary task of the 1960's was to demonstrate that a pre-Cambrian fossil record existed. In the 1970's and 1980 's, it was to demonstrate that the record was rich. The task for the 1990's is to document the Proterozoic paleontological record in sufficient systematic, paleoecological, and stratigraphic detail to fulfill the promise of Tyler and Barghoorn's discovery.

\section{SYSTEMATIC PALEONTOLOGY}

Systematic descriptions for many Draken species can be found in Knoll (1982). In this paper, discussion is limited to those previously described taxa for which significant new information is available and to species not discussed in Knoll (1982). All type and illustrated specimens are reposited in the Paleobotanical Collections of the Harvard University Herbaria.

Kingdom Eubacteria Woese and Fox, 1977

Phylum Cyanobacteria Stanier et al., 1978 Class COCCOGONEAE Thuret, 1875

Order CHROOCOCCALES Wettstein, 1924

Family CHROOCOCCACEAE Nägeli, 1849

Genus GloeOdiniopsis Schopf, 1968, emend. Knoll and Golubic, 1979

Type species. - Gloeodiniopsis lamellosa, Schopf, 1968, emend. Knoll and Golubic, 1979.

\section{GLOEODINIOPSIS GRANDIS Sergeev and Krylov, 1986} Figure 19.4

Discussion. - The genus Gloeodiniopsis is recognized on the basis of its multiple envelopes and common presence of $2-4$ daughter cells within the multilamellate vesicle. Rare individ-

FIGURE 12-Polybessurus bipartitus silicified in the lower flake conglomerate (1-7), and calcified (8). 1, P-4353-7B, Z22/4, HUHPC \#62381; 2 , W(P)-839-B, Q30/0, HUHPC \#62382), 3, P-91-3A, F36/1, HUHPC \#62383; 4, P-4353-7A, F15/0, HUHPC \#62384; 5, P-4353-1A, O25/4, HUHPC \#62385; 6, a cluster, M-13D-8A, V23/0, HUHPC \#62386; 7, B. bipartitus (large vesicle) among diverse microfossils; 8, crust-forming Polybessurus population preserved by dolomitic coatings in leached and fenestrate dolomite (slide $\mathrm{P}(\mathrm{F})-7019)$. Bar in $5=20 \mu \mathrm{m}$ in $1-5 ;=60$ $\mu \mathrm{m}$ in 6 and 7 ; and $=1,000 \mu \mathrm{m}$ in 8 . 

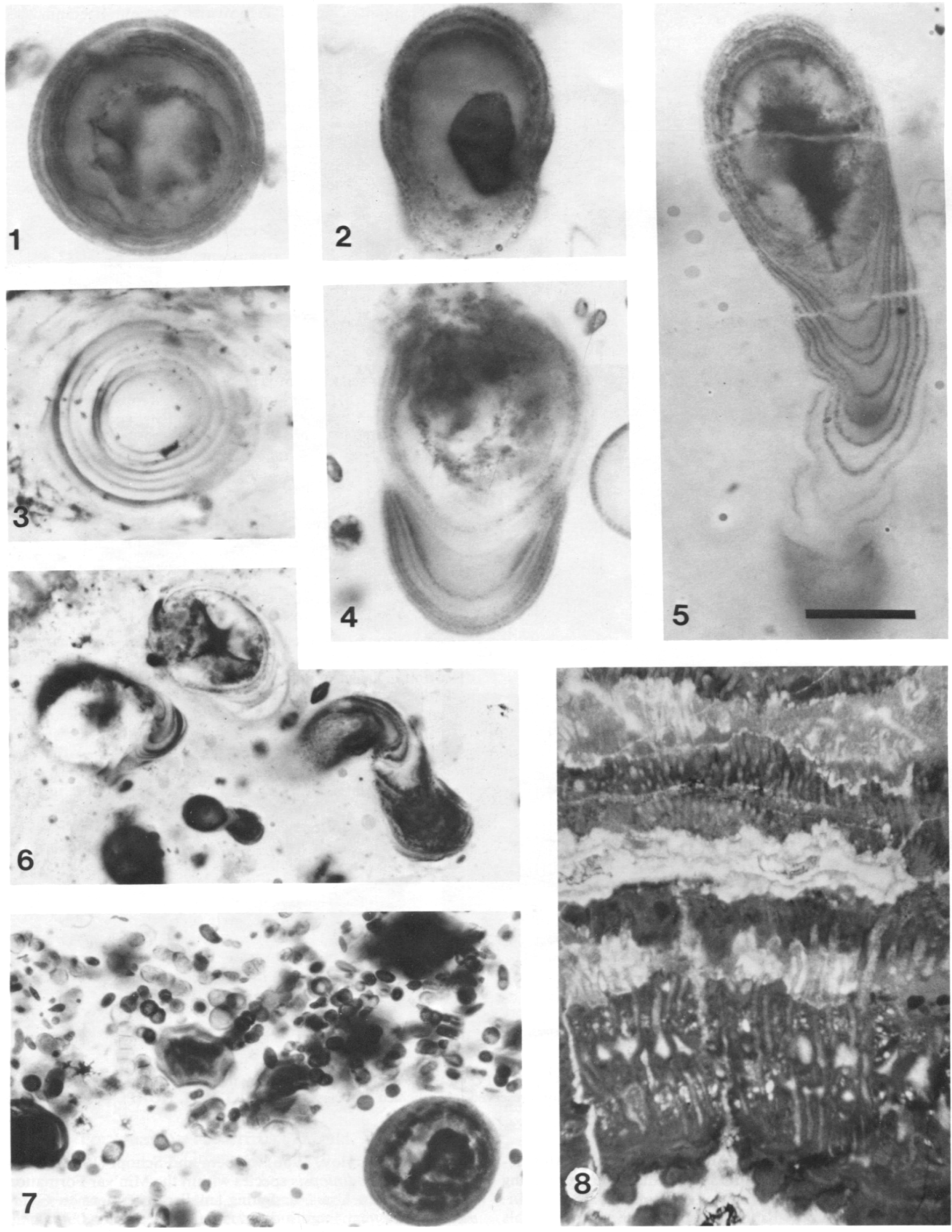

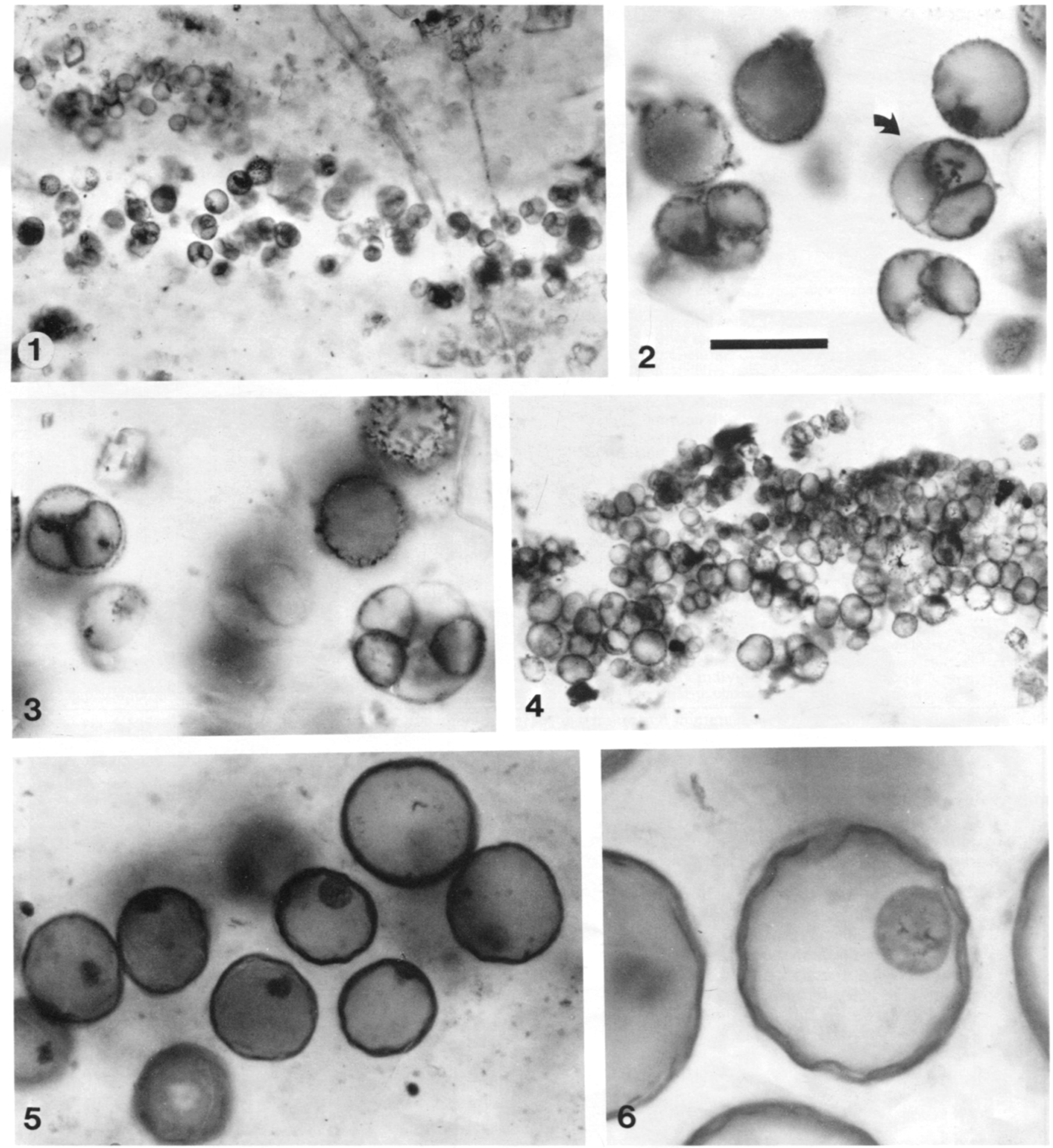

FIGURE 13-1-4, Myxococcoides chlorelloidea (M-21-1A, S24/2, HUHPC \#62354); 2, specimen marked by the arrow is designated as the type of the species. 5, 6 (detail), ?Leiosphaeridia crassa population preserved in a silicified mat clast (P-4353-7G, V-17, HUHPC \#62387). Bar in $2=50 \mu \mathrm{m}$ in 1,4 , and 5 ; and $=20 \mu \mathrm{m}$ in 2,3 , and 6 .

uals within the thin-walled $S$. inornatum biofacies fit this description. Their large size (up to $32 \mu \mathrm{m}$ in diameter, containing four ellipsoidal inner vesicles) invites comparison with $G$. grandis described from Upper Riphean cherts of the southern Urals
(Sergeev and Krylov, 1986). Nyberg and Schopf (1984) recognized two Gloeodiniopsis species within the Min'yar Formation of the southern Urals, assigning smaller specimens to $G$. lamellosa and very large individuals $(31-51 \mu \mathrm{m})$ to $G$. magna. 
Gloeodiniopsis magna differs from $G$. grandis in that dyads and tetrads are not apparent.

It is known that Polybessurus bipartitus occurs in Min'yar cherts (V. Sergeev, personal commun.) and that Polybessurus individuals without stalks resemble large chroococcoid cells (see Figure 12.1). Therefore, in the absence of evidence for a Gloeodiniopsis-like divisional cycle, the proper interpretation of $G$. magna remains in doubt. For these reasons, we have chosen to include the Draken fossils within $G$. grandis. In its morphological features, this fossil compares with living species of Chroococcus (Knoll and Golubic, 1979; Sergeev and Krylov, 1986).

Genus SPHAEROPHYcus Schopf, 1968

Type species. - Sphaerophycus parvum Schopf, 1968.

SPHAEROPHYCUS MEDIUM Horodyski and Donaldson, 1980 Figure 19.3

Sphaerophycus medium HoRODYSKI AND DoNALDSON, 1980, p. 140141 , figs. 5J, 6A, 6B.

Sphaerophycus wilsonii KNOLL, 1982, p. 783-784, Pl. 9, figs. 5-9.

Discussion. - Hofmann (personal commun.) has suggested that Draken populations assigned by Knoll (1982) to $S$. wilsonii have a size frequency distribution and cell-division pattern comparable to those of $S$. medium. Having reexamined described specimens and additional material, we concur and thus place $S$. wilsonii in synonymy with $S$. medium.

Family ENTOPHYSALIDACEAE

Genus EOENTOPHYSALIS Hofmann, 1976, emend. Mendelson and Schopf, 1982

Type species. - Eoentophysalis belcherensis Hofmann, 1976.

EOENTOPHYSALIS BELCHERENSIS Hofmann, 1976

Figure 16.5, 16.6

Description. - Irregularly spheroidal colony composed of ovoid vesicles $8-15 \mu \mathrm{m}$ long $\left(\bar{x}=11.6 \mu \mathrm{m} ; \mathrm{s}_{\mathrm{x}}=3.6 \mu \mathrm{m} ; \mathrm{N}=52\right)$ with multiple (1-3) thick lamellae. Individual vesicles contain 1-16 smaller, thin-walled vesicles, often with a small internal bleb of dense organic matter. "Unit" vesicles in groups of 8-16 (rarely 32 ), these groups forming a loose spheroidal colony.

Discussion. - This population is indistinguishable from $E$. belcherensis, originally described from the Paleoproterozoic Belcher Supergroup, Canada (Hofmann, 1976). Unlike the type and many subsequently described populations, the Draken fossils do not constitute dominant mat-builders. Perhaps this is because the Draken tidal flat did not form along a semiarid coastline. Today, Entophysalis major is a minor component of mat communities on mesic Bahamian tidal flats (S. Golubic, personal commun.). Within the Draken Conglomerate Formation, $E$. belcherensis is rare, occurring only as an isolated population in a lower flake conglomerate mat clast. Comparable populations are rare elements in $S$. inornatum mat assemblages from correlative beds in East Greenland (Green et al., 1989).

Order Pleurocapsales Geitler, 1925

Family DERMOcARPACEAE Geitler, 1925

Genus POLYBESSURUS Fairchild, 1975, ex Green et al., 1987

Type species. - Polybessurus bipartitus Fairchild, 1975, ex Green et al., 1987.

POLYBESSURUS BIPARTITUS Fairchild, 1975, ex Green et al., 1987

Figure 12

Description. - Thick-walled, multilamellate vesicles 30-70 $\mu \mathrm{m}$ in diameter. May be spheroidal or ellipsoidal with lamellae

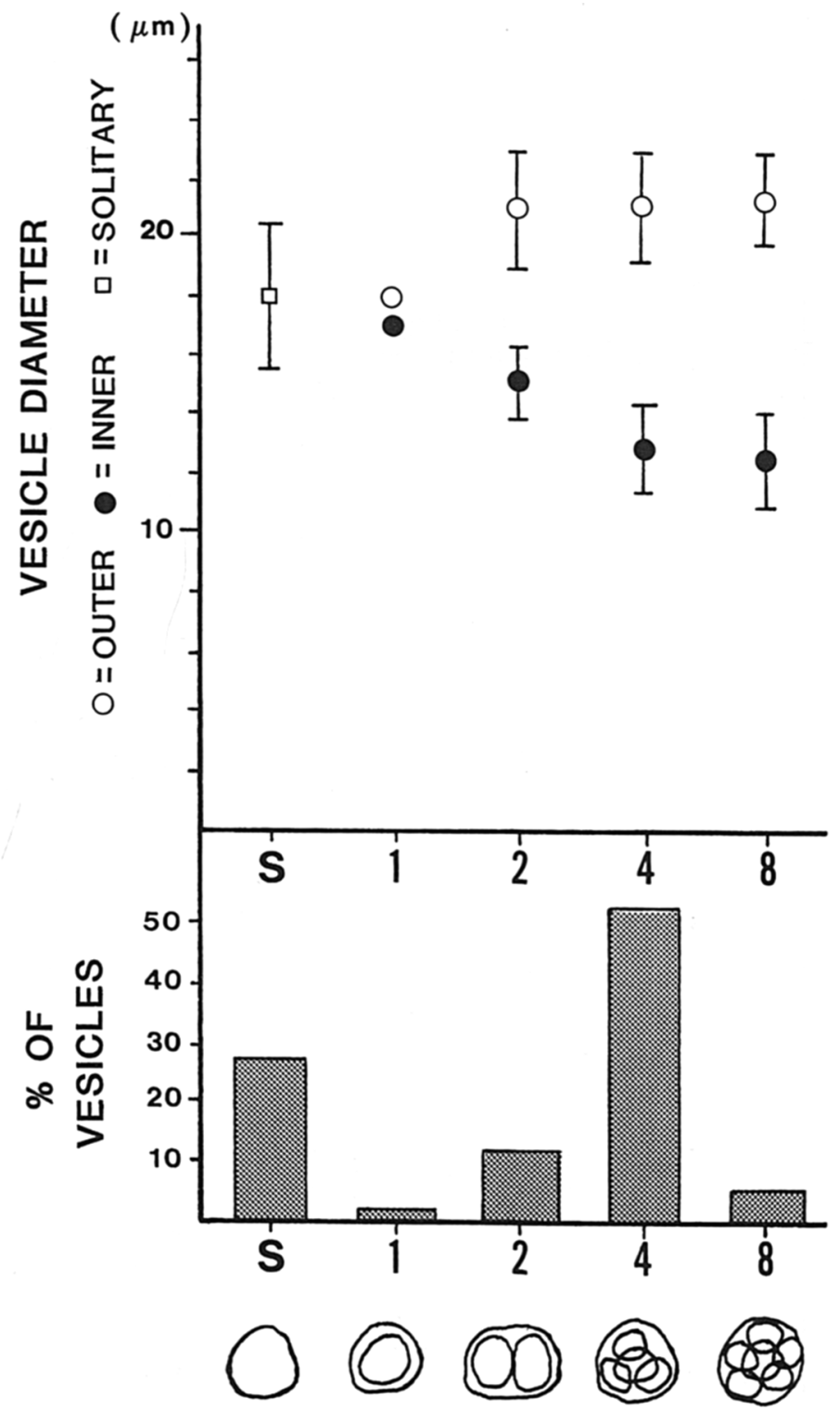

FIGURE 14-Size distribution of Myxococcoides chlorelloidea inner and outer (or solitary) vesicles, ordered by number of inner vesicles per outer vesicle.

elongated to form a short or long (up to $400 \mu \mathrm{m}$ ) stalk. Reproduction inferred to be by multiple fission.

Discussion. - In Draken cherts, $P$. bipartitus specimens occur principally as isolated individuals or loose clusters of several individuals within diverse $S$. inornatum mats. In correlative beds in East Greenland, $P$. bipartitus populations form local monospecific crusts among low-diversity $S$. inornatum mats. Polybessurus crusts in the Draken Formation are preserved by dolomitic rinds. Draken Polybessurus were not recognized by Knoll (1982), but restudy of his material indicates that a specimen illustrated as Salome svalbardensis (not the type) should be reassigned to $P$. bipartitus (Knoll, 1982, Pl. 2, fig. 2).

Family XENOCOCCACEAE Ercegovic, 1932

Genus SYNODOPHYCUS Knoll, 1982, emend.

Type species. - Synodophycus euthemos Knoll, 1982.

Emended diagnosis. - Pluricellular aggregates of small $(<12$ 
$\mu \mathrm{m})$, approximately equidimensional hyaline unit vesicles closely packed together in an irregularly ellipsoidal colony of 16-64 (rarely more) unit vesicles; colonies may be enclosed within a thin envelope, but internal membrane-enclosed vesicle packets are rare or absent; binary division in three planes; within colonies, one or a small number of individual vesicles may be enlarged and contain two or more small cell-like vesicles.

\section{SYNODOPHYCUS EUTHEMOS Knoll, 1982, emend.} Figure 15.1-15.9

Emended diagnosis. - Qualitatively, as for genus. Unit vesicles 4-7 $\mu \mathrm{m}$; colonies irregularly ellipsoidal to slightly lobed, 20-40 $\mu \mathrm{m}$ long and 15-30 $\mu \mathrm{m}$ wide, containing 16-64 unit vesicles (rarely more). Uncommonly, individual vesicles in colony enlarged to $11-15 \mu \mathrm{m}$ and containing 4-8 small (1-2 $\mu \mathrm{m})$ vesicles.

Discussion. - Synodophycus euthemos was described by Knoll (1982) from a single distinctive colony in Draken chert. The defining features of the taxon were considered to be the presence of inner and outer vesicles in colony units and the distinctive close-packing of vesicles into a spheroidal colony. Inner and outer vesicles were interpreted as shrunken cell remains and envelopes, respectively, while the colony was seen as the product of repeated binary divisions in three directions. More recently collected material contains abundant colonies of $S$. euthemos that permit a clearer understanding of its biology and systematic position. Inner vesicles do indeed appear to be shrunken cell remnants within (originally) tightly adhering F-layers; however, inner vesicles are irregular features of colonies. Thus, they have been excluded from the generic and specific diagnoses. More significantly, several colonies exhibit enlarged unit vesicles that contain 4-8 small inner vesicles. These are interpreted as baeocytes formed by cell enlargement followed by multiple fission. This adds greatly to the morphological distinctness of the population and allows it to be placed systematically within the cyanobacterial family Xenococcaceae (Ercegovic, 1932; Komarek and Anagnostidis, 1986). Synodophycus populations appear to be particularly similar to species of the extant genera Myxosarcina and Chroococcidiopsis, both of which form sarcinoid cell packets by repeated binary divisions in three planes and facultatively form baeocytes from individual spherically enlarged cells within colonies (Waterbury and Stanier, 1978; Komarek and Anagnostidis, 1986).

Draken Synodophycus populations are widely distributed and locally abundant dwellers within Siphonophycus inornatum mats (contra Knoll, 1982). Among Proterozoic microfossils described from other formations, they most closely resemble Phacelogeminus lineatus from the Neoproterozoic Tindir Formation, northwestern Canada (Allison and Awramik, 1989). Indeed, the two taxa may be synonymous, but in the absence of information on baeocyte formation in the Canadian fossils, formal synonymy is premature.

Incertae sedis

Genus CoNIUNCTIOPHYCUS Zhang, 1981

Type species.-Coniunctiophycus gaoyuzhuangense Zhang, 1981 .

\section{CONIUNCTIOPHYCUS MAJORINUM sp. nov.}

Figure 16.1-16.4

Diagnosis. - A species of Coniunctiophycus characterized by small spheroidal to ellipsoidal unit vesicles $(2-4 \mu \mathrm{m})$ arranged in packets that form large (50-100 $\mu \mathrm{m}$ long and $30-75 \mu \mathrm{m}$ wide) smooth to lobate ellipsoidal colonies.

Description. - Pluricellular aggregates (colonies) consisting of small spheroidal to ellipsoidal unit vesicles that commonly contain a single dense organic bleb less than a micron in diameter. Unit vesicles $2-4 \mu \mathrm{m}$ in diameter $\left(\mathrm{x}=3.3 \mu \mathrm{m} ; \mathrm{s}_{\mathrm{x}}=0.5 \mu \mathrm{m} ; \mathrm{N}\right.$ $=275$ ) and tightly appressed in packets of 2-8 individuals (range $\left.=5-12 \mu \mathrm{m} ; \mathrm{x}=6.1 \mu \mathrm{m} ; \mathrm{s}_{\mathrm{x}}=1.0 \mu \mathrm{m} ; \mathrm{N}=125\right)$. Packets in colony interiors approximately equidimensional, but surficial packets commonly elongated perpendicular to colony surface; length : width ratios in surficial packets commonly $2: 1$. Packets not clearly enclosed in a common envelope, but within packets interior vesicle walls commonly poorly defined, giving impression of larger units. Packets commonly arranged in larger packets 15-20 $\mu \mathrm{m}$ long. These larger packets may form distinct lobes, or may be cryptic; commonly accentuated during post-mortem degradation. Unit vesicles, small packets, and larger packets comprise smooth to lobate ellipsoidal colonies 55-110 $\mu \mathrm{m}$ long $\left(\mathrm{x}=70 \mu \mathrm{m} ; \mathrm{s}_{\mathrm{x}}=17 \mu \mathrm{m} ; \mathrm{N}=32\right)$ and $30-75 \mu \mathrm{m}$ wide $(\mathrm{y}=46$ $\mu \mathrm{m} ; \mathrm{s}_{\mathrm{y}}=12 \mu \mathrm{m} ; \mathrm{N}=32$ ). Colony elongation parallel to bedding. No evidence of cell differentiation within colonies.

Etymology. - With reference to the fact that colonies in this species are larger than those of other described species within the genus.

Type specimen. - The specimen illustrated in Figure 16.4 has been chosen as the type and is in the Paleobotanical Collections of the Harvard University Herbaria under catalog number 62353.

Type locality. - South face of Dracofjella nunatak along Polarisbreen glacier, Ny Friesland, Spitsbergen.

Discussion.-Coniunctiophycus majorinum colonies occur abundantly within a single shard of Siphonophycus septatum mat in the lower flake conglomerate beds. Their sarcinoid colony form compares closely to that expressed by certain pleurocapsalean cyanobacteria, especially species of Myxosarcina and Chroococcidiopsis (Waterbury and Stanier, 1978). On the other hand, other cyanobacteria (e.g., Entophysalis spp.) can form comparable morphologies as can other Eubacteria and certain protists (e.g., Chlorosarcina); thus, in the absence of baeocytes, no firm systematic attribution can be made.

The Draken population conforms in all salient features to Zhang's (1981) generic diagnosis for Coniunctiophycus and, indeed, has unit vesicles comparable in size to those of the type species C. gaoyuzhuangense (Zhang, 1981); however, its characteristic colony size and shape differ substantially from the type and other described species of Coniunctiophycus, justifying the recognition of a new species. Gaoyuzhuang Coniunctiophycus species bear an uncertain relationship to Eoentophysalis colonies in the same formation, but no close relationship appears likely between Draken Coniunctiophycus and Eoentophysalis.

This Draken population bears some resemblance to sarcinoid colonies of Scissilosphaera regularis from the Ryssö Formation of neighboring Nordaustlandet (Knoll and Calder, 1983), but

FIGURE 15-1-9, Synodophycus euthemos. 1-3, P-4353-7G, E21/0, HUHPC \#62388; 4, type specimen, W(P)-837-B, Q22/4, HUHPC \#60493; 5 , specimen containing small cells interpreted as baeocytes (P-91-2A), W24/4, HUHPC \#62389); 6, 8, vesicles with probable baeocytes, note Eosynechococcus medius in 8, P-4353-7B, Z21/0, HUHPC \#62390; 7, showing effects of variable degradation, P-4353-12F, N29/2, HUHPC \#62397; 9, cluster of vesicles containing probable baeocytes, P-4353-7G, H17/3, HUHPC \#62391; 10-12, Sphaerophycus parvum; 10, M-131B, K28/1, HUHPC \#62392; 11, P-13-13A, W20/4, HUHPC \#62393; 12, W(P)-839-A, L36/4, HUHPC \#62394. Bar in $6=20 \mu \mathrm{m}$ in 1 ; = $15 \mu \mathrm{m}$ in $2-8 ;=30 \mu \mathrm{m}$ in 9 ; and $=10 \mu \mathrm{m}$ in $10-12$. 
KNOLL ET AL.-NEOPROTEROZOIC MICROFOSSILS

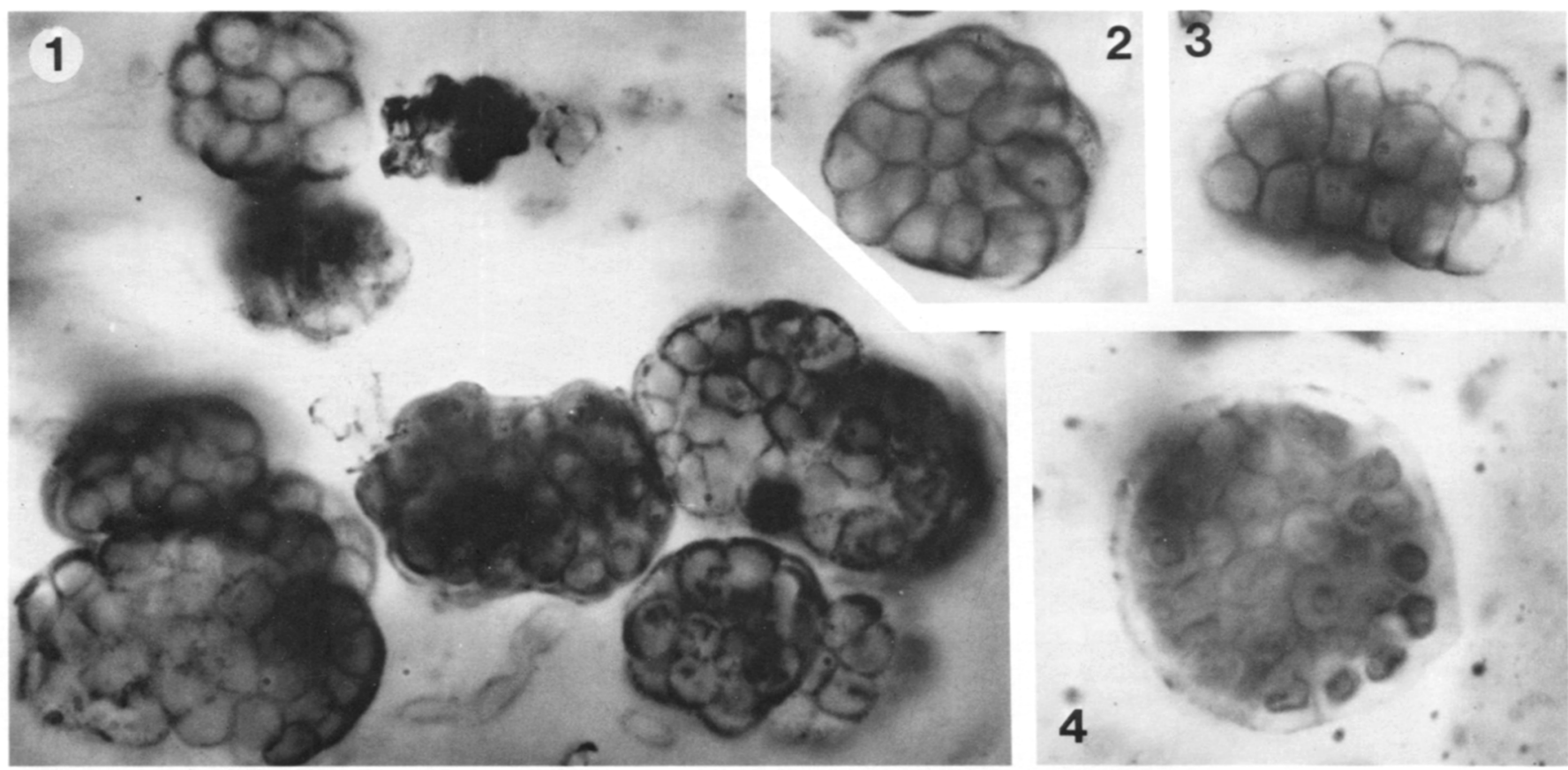

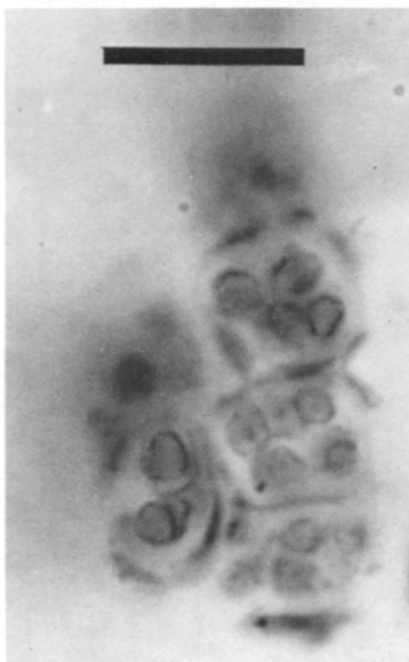

6

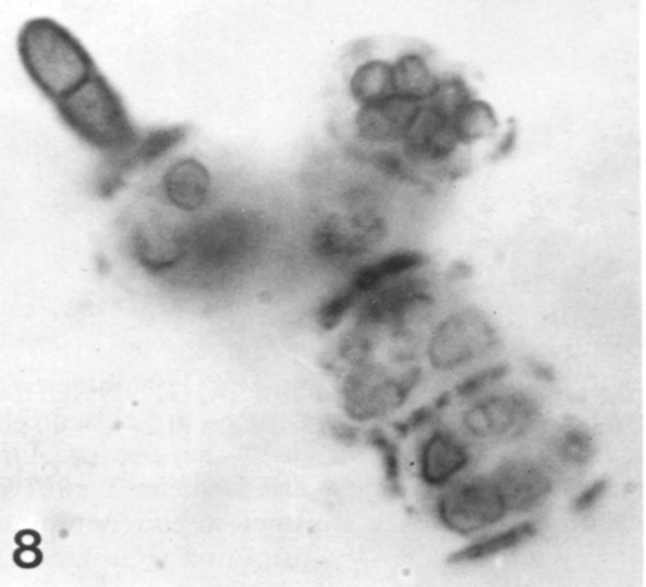

5

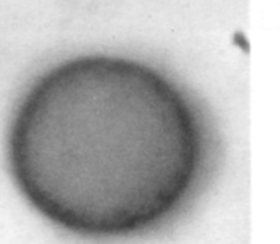

\section{7}
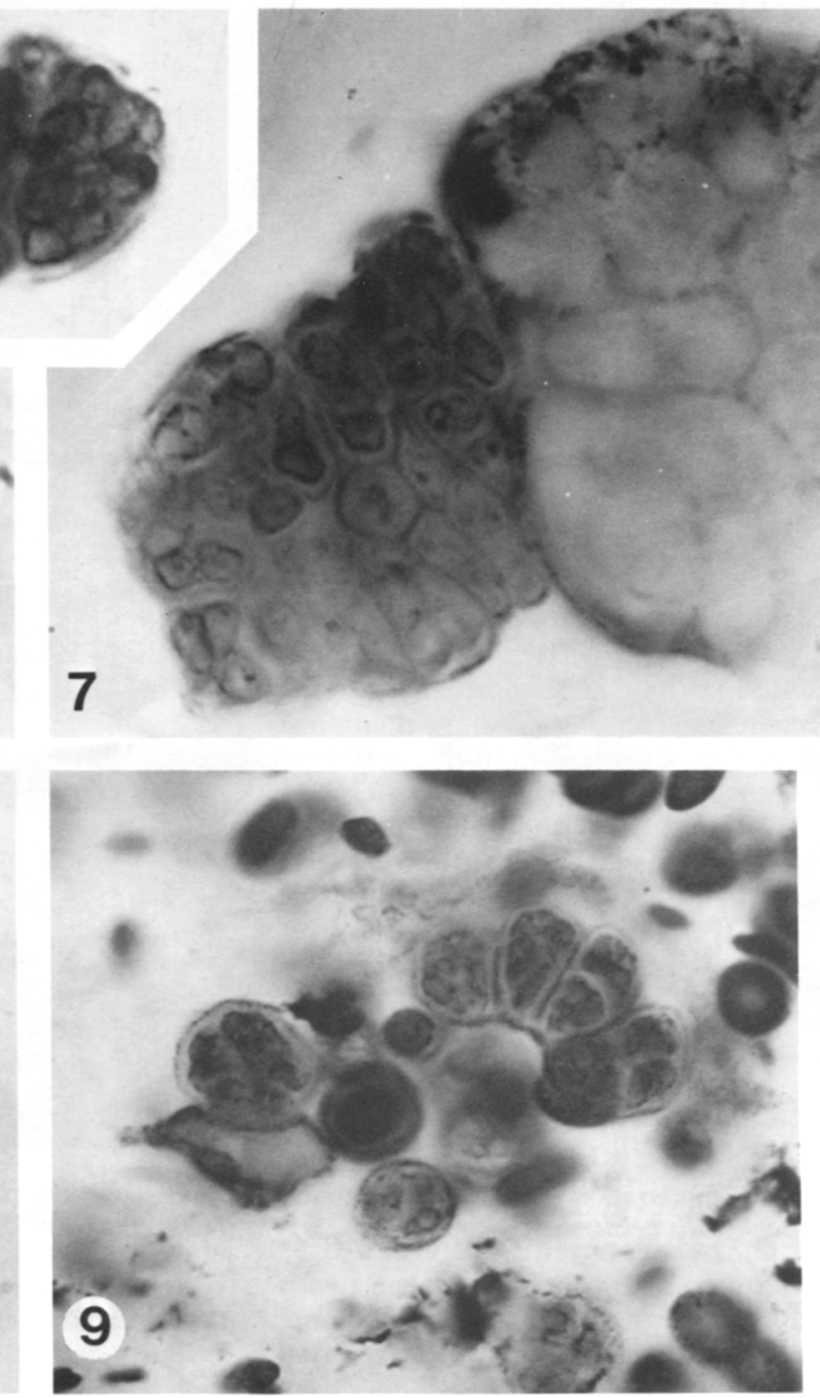

10

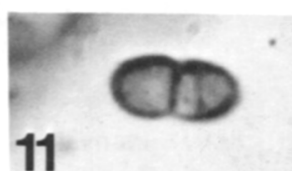

12 

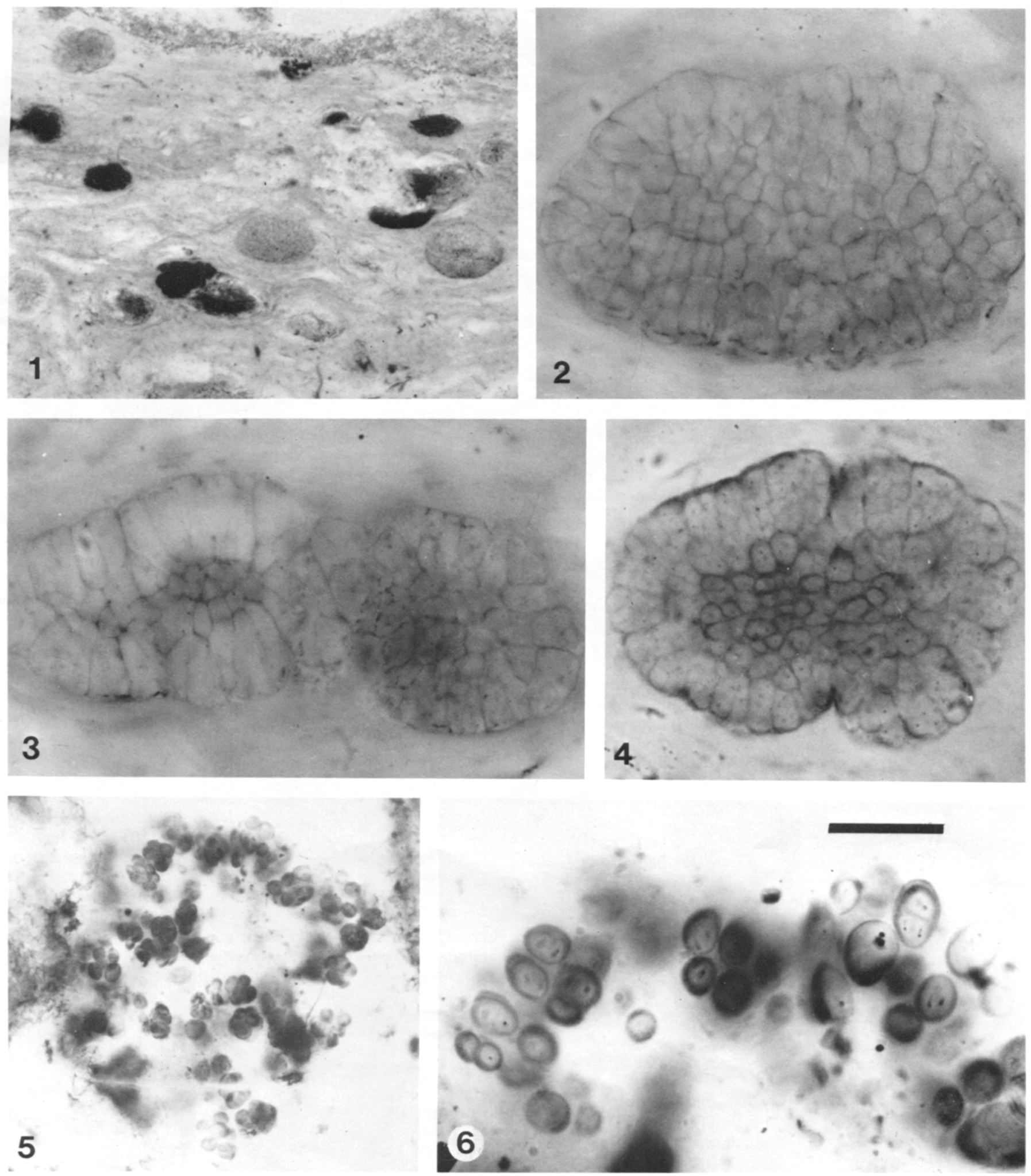

FIGURE 16-1-4, Coniunctiophycus majorinum sp. nov. (the specimen in 4 is designated as the type of the species; M-13B-2A, G11/1, HUHPC \#62353). 5, 6 (detail), Eoentophysalis belcherensis, P-4353-13A, Q17/1, HUHPC \#62395. Bar in $6=120 \mu \mathrm{m}$ in $1 ;=20 \mu \mathrm{m}$ in $2-4 ;=80 \mu \mathrm{m}$ in 5 ; and $=25 \mu \mathrm{m}$ in 6 . 
lacks the clear multiple fission pattern evident in that taxon. It also resembles colonies described as Palaeoanacystis magna from the Tindir Formation, Canada (Allison and Awramik, 1989). The Tindir material should certainly be transferred to the genus Coniunctiophycus, but its apparently larger unit vesicle size and lack of elongated surface packets suggest that it should be regarded as distinct from the Draken material at the species level. Finally, one can ask whether this population might be related to Draken Synodophycus euthemos. Both form sarcinoid colonies, but $S$. euthemos has baeocytes, unequivocally larger unit cells, and distinctly different colony form and size.

Genus Cymatiosphaeroides Knoll, 1984, emend.

Type species. - Cymatiosphaeroides kullingii Knoll, 1984.

Discussion. - A single specimen of $C$. kullingii was observed in interstitial space within the upper flake conglomerate. The specimen has a robust inner vesicle with a diameter of $125 \mu \mathrm{m}$ connected by numerous slender (ca $1 \mu \mathrm{m}$ ) solid processes 5-6 $\mu \mathrm{m}$ long to a thin outer vesicle $141 \mu \mathrm{m}$ in diameter. The outer vesicle is, in turn, surrounded by four extremely thin external envelopes.

This specimen and numerous individuals in the subjacent Svanbergfjellet Formation (Butterfield, personal commun.) contain features not described from the Hunnberg Formation holotype (Knoll, 1984), although reexamination shows them to be present. Therefore, emended generic and specific diagnoses are warranted.

Emended diagnosis. - Spheroidal to ellipsoidal vesicle; inner wall robust, bearing numerous thin (ca $1 \mu \mathrm{m}$ ) solid cylindrical processes that connect to a thin single or multilamellate outer wall; processes thicken at both ends and are regularly distributed over the vesicle; no interconnecting septa and no division of vesicle into polygonal fields by septa or membranes; outer wall has a relatively thick inner layer and up to six thin outer membranes; outer membranes may not be evident in partially degraded specimens.

CYMATIOSPHAEROIDES KULLINGII Knoll, 1984, emend. Figure 4.4, 4.6

Emended diagnosis. -Qualitatively, as for genus; inner wall diameter 70-300 $\mu \mathrm{m}$; outer wall multilamellate, 80-320 $\mu \mathrm{m}$ in diameter; processes 4-7 $\mu \mathrm{m}$ long.

Discussion. - Cymatiosphaeroides kullingii specimens in the Draken, Svanbergfjellet, and Hunnberg Formations all occur in very shallow, coastal-marine facies. Their systematic affinities are obscure.

Genus EOSYNECHOcoccus Hofmann, 1976

Type species. - Eosynechococcus moorei Hofmann, 1976.

\section{EOSYNECHOCOCCUS sp.}

Figure 17.16-17.22

Description. - Small elongate rods, 7-12 $\mu \mathrm{m}$ long and ca $1 \mu \mathrm{m}$ wide. Rods occur as solitary individuals or as paired vesicles joined end to end.

Discussion. - Four species of Eosynechococcus occur in Draken cherts. (Eosynechococcus sp. of Knoll (1982) is here considered to be a variant of $E$. medius.) All could be the remains of chroococcalean cyanobacteria, but all could alternatively be the remains of physiologically dissimilar Eubacteria. Therefore, the fossils are treated as incertae sedis. Eosynechococcus sp. differs from previously described species in its narrow width. Within Draken cherts, these fossils occur sporadically in Siphonophycus inornatum assemblages containing abundant Gloeodiniopsis mikros.
Genus GerminosPHAERA Mikhailova, 1986

Type species. - Germinosphaera unispinosa Mikhailova, 1986.

\section{GERMINOSPHAERA sp.}

Figure 19.6

Discussion. - Knoll (1982) noted the presence in Siphonophycus septatum mats of spheroidal vesicles from which a single tube extends. Similar fossils have been described from the Soviet Union under the name Germinosphaera. Mikhailova (1986) recognized two species based on the presence of one or two tubular projections. Insofar as Draken individuals may contain either one or two projections, we suspect that Mikhailova's two species may come from a single population. Pending restudy of type materials, we refer to the Draken specimens as Germinosphaera sp. The systematic affinities of this population are obscure, although Butterfield et al. (1988) noted that comparable morphologies are exhibited by germinating zoospores of the xanthophyte alga Vaucheria.

\section{Genus GORGONISPHAERIDIUM}

Staplin, Jansonius, and Pocock, 1965

Type species. - Gorgonisphaeridium winslowii Staplin, Jansonius, and Pocock, 1965.

\section{GORGONISPHAERIDIUM MAXIMUM (Yin) comb. nov.}

Figure 21.13

Basionym. - Baltisphaeridium maximum YIN, 1987, p. 439-440, Pl. 14 , figs. 14,15 .

Holotype.-The specimen figured by Yin (1987, Pl. 14, figs. 14, 15).

Description. - A single incomplete specimen of this large, echinate acritarch was observed in the Draken shale assemblage. Specimen is $112 \mu \mathrm{m}$ long (by extrapolation, complete vesicle would have been roughly $200 \mu \mathrm{m}$ in diameter) and bears numerous closely packed processes. Processes solid, unbranched, bluntly conical, and approximately $4 \mu \mathrm{m}$ long.

Discussion. - The Draken fossil appears to be conspecific with acritarchs from the Doushantuo Formation, China, that have been described as Baltisphaeridium maximum Yin, 1987. True Baltisphaeridium species differ from $B$. maximum in having relatively long and flexible, hollow processes that are constricted at their bases. Thus, Baltisphaeridium is not the appropriate genus for these fossils. Spheroidal acritarchs bearing solid, echinate processes are placed in the genus Gorgonisphaeridium. $\mathrm{Nu}$ merous Paleozoic species have been described, and although all are much smaller than the specimen described here, they share with it a common process architecture. Therefore, the Draken and Doushantuo fossils are placed in the new combination, Gorgonisphaeridium maximum. Zang (1989) assigned three forms from the uppermost Proterozoic Pertatataka Formation, Australia, to Gorgonisphaeridium, but claimed that his specimens have hollow processes. If correct, these fossils must be assigned to another genus.

Genus LeIOSPHAERIDIA Eisenack, 1958, emend. Downie and Sarjeant, 1963

Type species. - Leiosphaeridia baltica Eisenack, 1958.

LEIOSPHAERIDIA CRASSA (Naumova) Jankauskas, 1989

Figures 13.5, 13.6, 21.4, 21.5

Discussion. - Unornamented sphaeromorph acritarchs in the size range of 30-70 $\mu \mathrm{m}$ are common in Draken shales and lagoonal carbonates and occur sporadically as allochthonous elements in Siphonophycus septatum mats. These simple forms 
are assigned to Leiosphaeridia crassa $(=$ L. asperata $=$ Kildinella hyperboreica; see synonymy in Jankauskas, 1989, p. 75).

\author{
LeIOSPHAERIDIA JACUTICA (Timofeev) \\ Mikhailova and Jankauskas, \\ in Jankauskas, 1989
}

Figures 19.5, 21.1

Discussion. - In a recent comprehensive revision of Proterozoic leiosphaerid acritarchs, Jankauskas (1989) and colleagues grouped thin-walled leiosphaerids in the size range 70-800 $\mu \mathrm{m}$ as $L$. jacutica. Draken shales contain leiosphaerids up to 265 $\mu \mathrm{m}$ in diameter, and a single thin-walled specimen $600 \mu \mathrm{m}$ in diameter was found in a clast of Siphonophycus septatum mat.

\section{LEIOSPHAERIDIA sp. cf. L. ATAVA (Naumova) Jankauskas, 1989 \\ Figure 21.2, 21.3}

Discussion. - Draken shales contain abundant fragments and less common entire specimens of large (up to $210 \mu \mathrm{m}$ ) leiosphaerid acritarchs bearing distinctively patterned wrinkles on relatively robust walls (Figure 21.3 ). The wrinkles are probably diagenetic; nonetheless, they appear to indicate a distinctive wall structure or chemistry. Among described forms, they are most similar to L. atava.

\section{Genus MYXococcoIdes Schopf, 1968}

Type species. - Myxococcoides minor Schopf, 1968.

\section{MYXOCOCCOIDES CANTABRIGIENSIS Knoll, 1982} Figure 11

Myxococcoides cantabrigiensis KNOLL, 1982, p. 784-785, Pl. 10, fig. 5, text-fig. 5.

Myxococcoides sp. A KNoLl, 1982, p. 785-786, Pl. 9, figs. 1, 2.

Myxococcoides sp. C KNOLL, 1982, p. 786, Pl. 6, figs. 1-3.

Discussion. - These abundant unicells are often found in association with solitary, relatively large vesicles described by Knoll (1982) as Myxococcoides sp. C. Figure 11.3 makes it clear that these two morphotypes are part of a single population; thus, large individuals are here included in $M$. cantabrigiensis. Thinwalled forms originally segregated as Myxococcoides $\mathrm{sp}$. A (Knoll, 1982) are likewise placed in synonymy with $M$. cantabrigiensis and are interpreted as degradational variants of this form.

Allison and Awramik (1989) considered M. cantabrigiensis and other Myxococcoides species to be cyanobacteria, stating (p. 272) that "there is no compelling evidence to indicate otherwise." We consider this statement to be only half correct. There is no definitive evidence linking most Myxococcoides species to any protistan group; however, there is equally no evidence indicating that these fossils are prokaryotic. Thus, we persist in considering these fossils as incertae sedis. The abundant presence of protists in Neoproterozoic rocks demonstrates that one cannot consider Neoproterozoic fossils as cyanobacteria until proven otherwise.

\section{MYXOCOCCOIDES CHLORELLOIDEA sp. nov.} Figure 13.1-13.4

Diagnosis. - A species of Myxococcoides characterized by single-walled vesicles $17-26 \mu \mathrm{m}$ in diameter, some of which contain internal $10-17 \mu \mathrm{m}$ vesicles in dyads, tetrads, and octads. Internal vesicles well rounded to hemispherical and commonly preserved better than external vesicles. Presence and organization of internal vesicles differentiate this species from other $M y x o$ coccoides species; lack of multiple lamellae and relatively greater proportion of vesicles that occur in tetrads distinguish this species from Gloeodiniopsis species.

Description. - Spheroidal to ellipsoidal vesicles arranged in loose aggregations or solitary. Vesicles with a single wall 17-26 $\mu \mathrm{m}$ in diameter (see Figure 14), ca $0.5 \mu \mathrm{m}$ thick, and hyaline to granular in surface texture; or vesicles of this description containing 1-8 (commonly four) spheroidal vesicles $10-17 \mu \mathrm{m}$ in diameter (see Figure 14) that fill outer vesicle. Inner vesicles well rounded or, in dyads, hemispherical; inner vesicles often darker and better defined than encompassing outer vesicles. Inner or solitary vesicles may contain an internal, wrinkled organic body.

Etymology. - With reference to the close resemblance of this population to living green algae of the genus Chlorella.

Type specimen. - This species can only be recognized on the basis of features revealed by a population; however, the botanical code of nomenclature requires that a single specimen be chosen as type. Therefore, the specimen in Figure 13.2 that is marked by an arrow has been chosen as the type and is reposited in the Paleobotanical Collections of the Harvard University Herbaria under catalog number 62354.

Type locality. - Atop MacDonaldryggen nunatak along the southern edge of Draken Conglomerate Formation exposure.

Discussion. - Species of Myxococcoides share the property of systematic intractability. Myxococcoides chlorelloidea shares this feature to a degree, but its distinctive divisional cycle involving one to three binary divisions with some but not much growth between successive splits (Figures 13,14 ) permits comparison to living green algae of the genus Chlorella. Populations of Chlorella pyredinosa exhibit a closely comparable range of morphologies and division patterns. Unfortunately, this simple life cycle is not unique to Chlorella; thus, $M$. chlorelloidea remains problematic.

FIGURE 17-1, Tetraphycus diminutivus (P-837-B, L8/4, HUHPC \#60517). 2-11, Gloeodiniopsis mikros. 2, M-13C-2a, 120/0, HUHPC \#62396; 3-5, 9, P-4353-12A, L27/0, HUHPC \#62398; 6-8, P4353-13A, H17/4, HUHPC \#62399; 10, P-4353-13A-1A, Q39/0, HUHPC \#62400; 11, W(P)-839-A, B16/3, HUHPC \#60515. 12, Eosynechococcus depressus, W(P)P-839-B, S32/0, HUHPC \#60509. 13-15, Eosynechococcus medius, 13, SP-15-\#A, H14/0, HUHPC \#62403; 14, M13B-1A, S22/3, HUHPC \#62402; 15, P-4353-7B, Z22/3, HUHPC \#62401. 16, Eosynechococcus sp. (arrow) dwarfed by Myxococcoides, P-4353-12B, C29/0, HUHPC \#62403. 17-22, Eosynechococcus sp., R-4353-\&B, Z21/0, HUHPC $\# 62404$. Bar in $12=10 \mu \mathrm{m}$ in $1,3-16 ;=20 \mu \mathrm{m}$ in 2 ; and $=15 \mu \mathrm{m}$ in $17-22$.

Figure 18-1-5, Myxococcoides sp. B. 1, 5, W(P)-839-C, G27/0, HUHPC \#60508; 2-4, M-13B-2A, X25/0, HUHPC\#62405. 6-10, Myxococcoides distola, sp. nov. 6-9, specimen marked by arrow in 9 is designated as the type of the species, M-13-4A, J21/0, HUHPC \#62406; 10, W(P)$839-\mathrm{C}, \mathrm{O} 36 / 2$, HUHPC \#60506. Bar in $1=60 \mu \mathrm{m}$ in 1 and $2 ;=15 \mu \mathrm{m}$ in $3-5,7,8$, and $10 ;=80 \mu \mathrm{m}$ in 6 ; and $=20 \mu \mathrm{m}$ in 9.

FIGURE 19-1, ?Leiosphaeridia sp., B-165A, M19/3, HUHPC \#62411. 2, unnamed form B, W(P)-8337, K30/3, HUHPC \#60529. 3, Sphaerophycus medium, W(P)-839-B, L10/3, HUHPC \#60527. 4, Gloeodiniopsis grandis, P-4353-13A, K38/2, HUHPC \#62407. 5, Leiosphaeridia jacutica P-4353-7E, J13/2, HUHPC \#62408. 6, Germinosphaera sp., P-4353-13A, V54/4, HUHPC \#62409. 7-9, Myxococcoides sp. E, P-4353-7G, L17/2, HUHPC \#62410. Bar in $8=20 \mu \mathrm{m}$ in $1-4,7$, and $9 ;=300 \mu \mathrm{m}$ in $5 ;=40 \mu \mathrm{m}$ in 6 ; and $=80 \mu \mathrm{m}$ in 8 . 

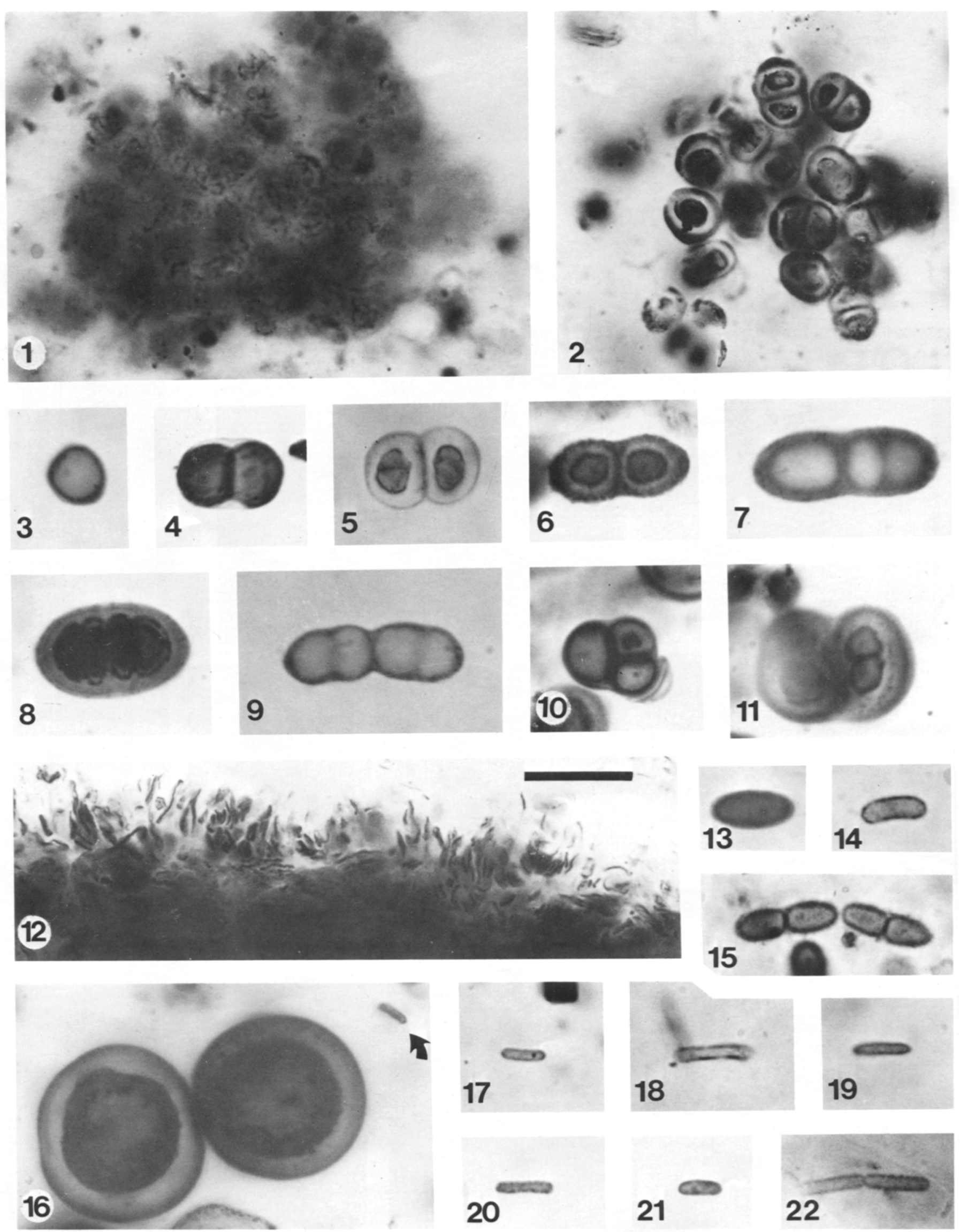


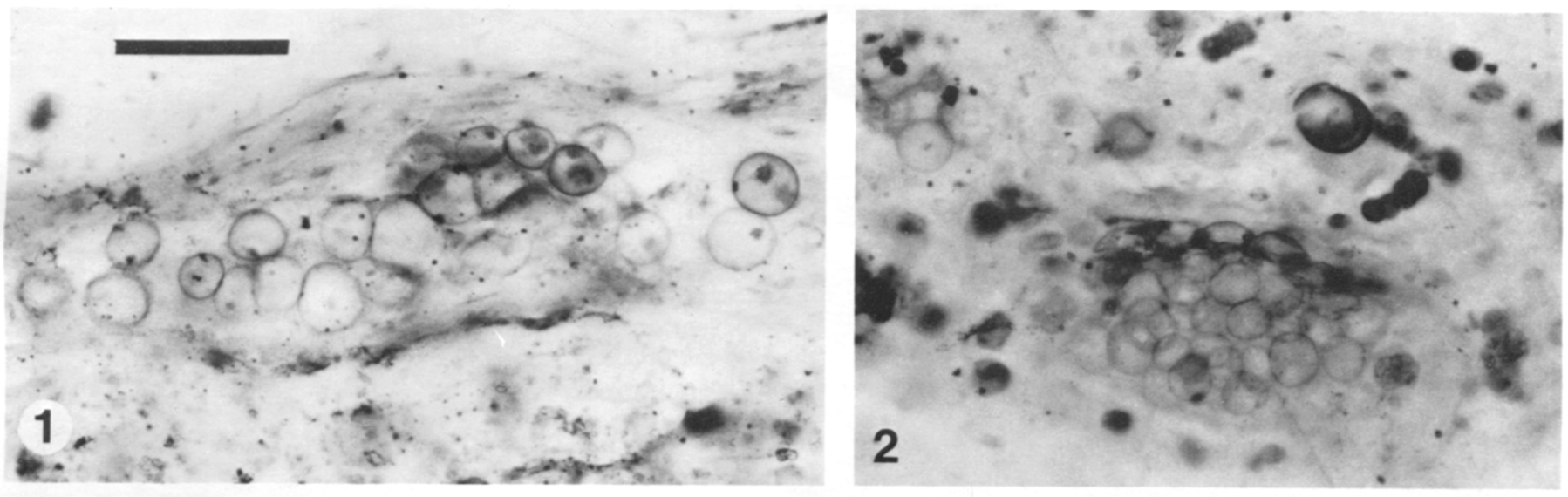

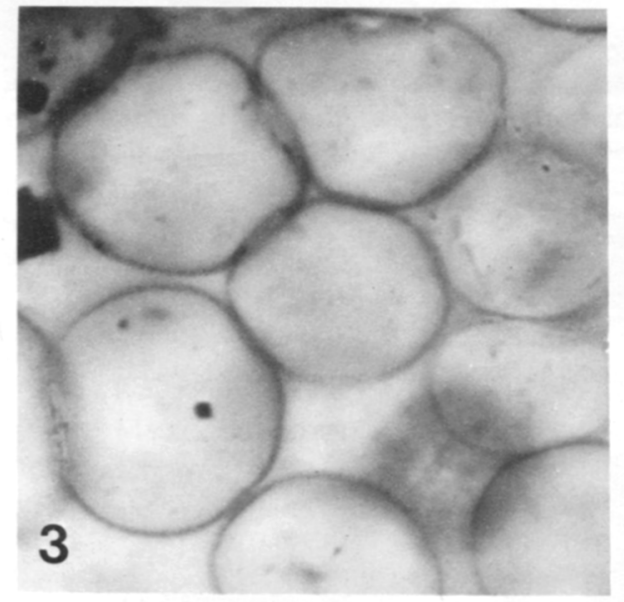
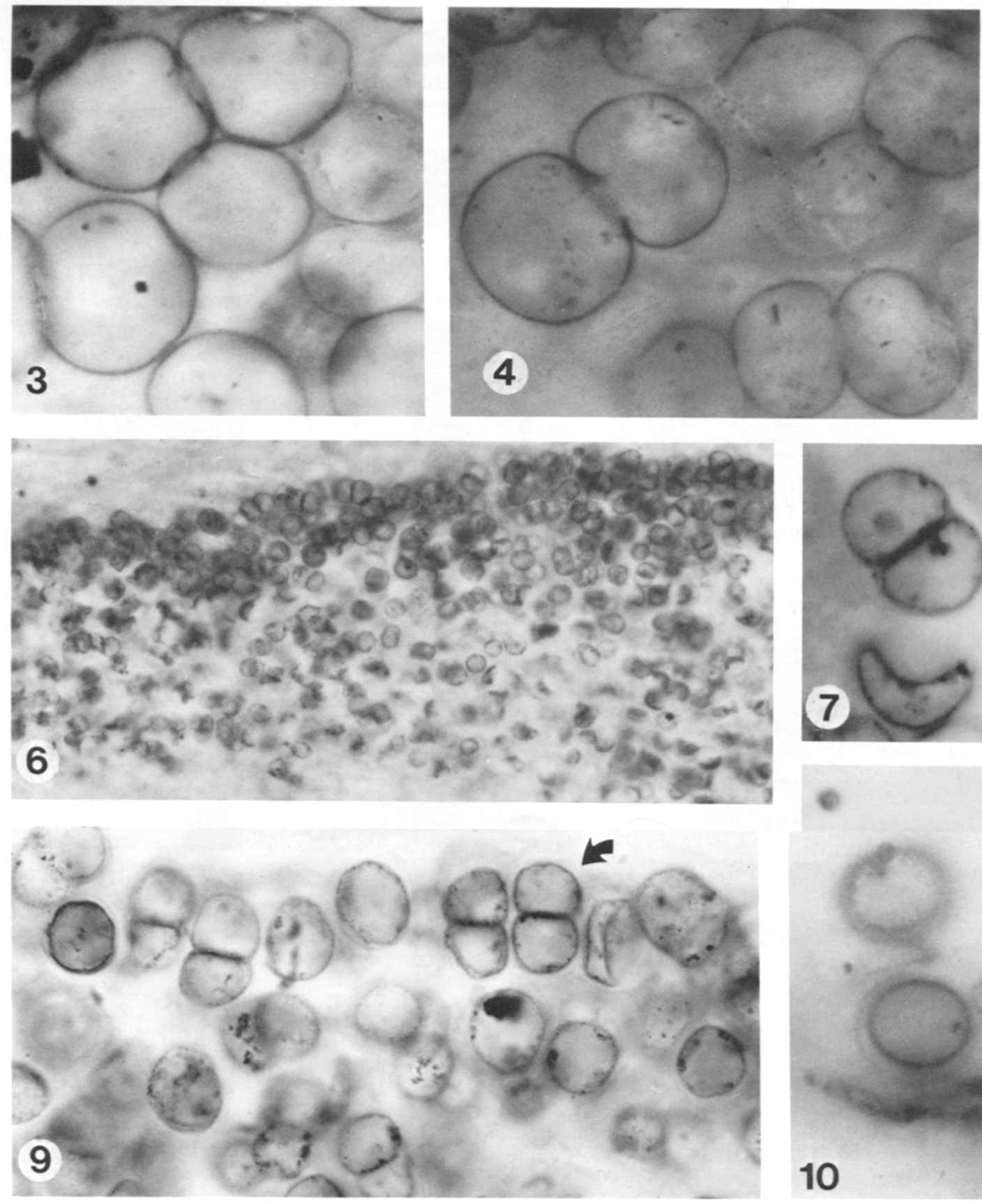
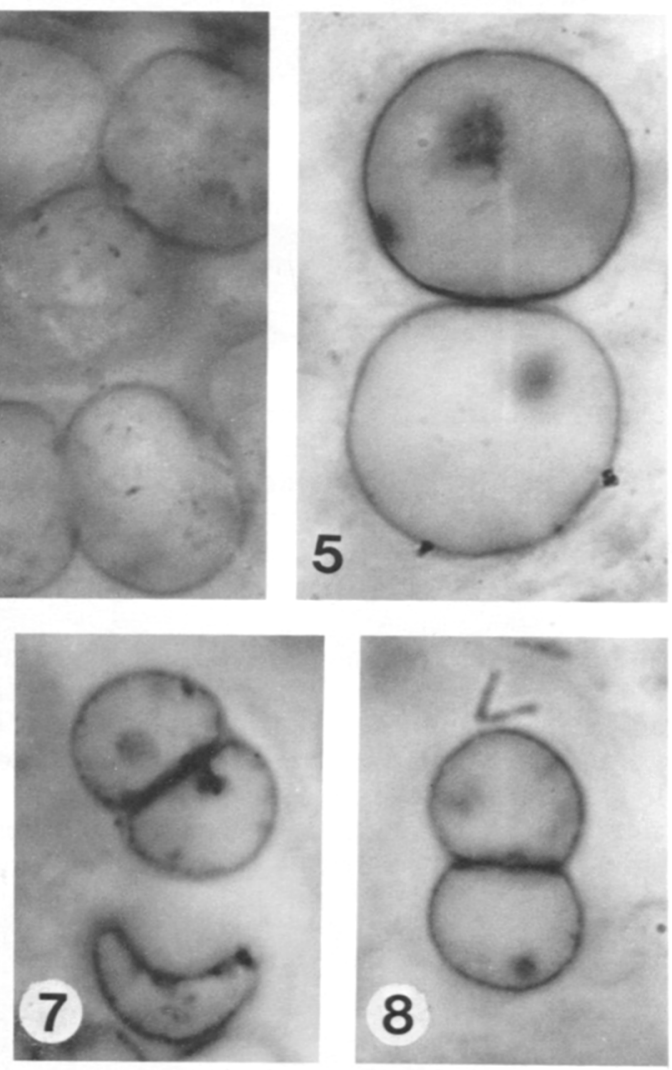

c

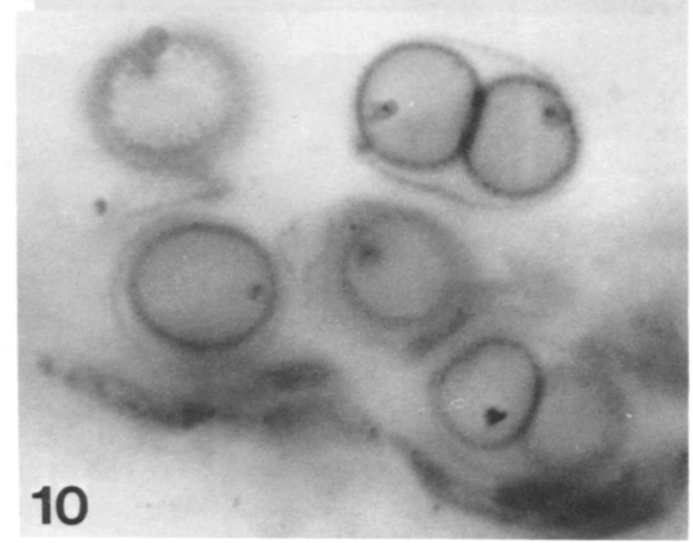



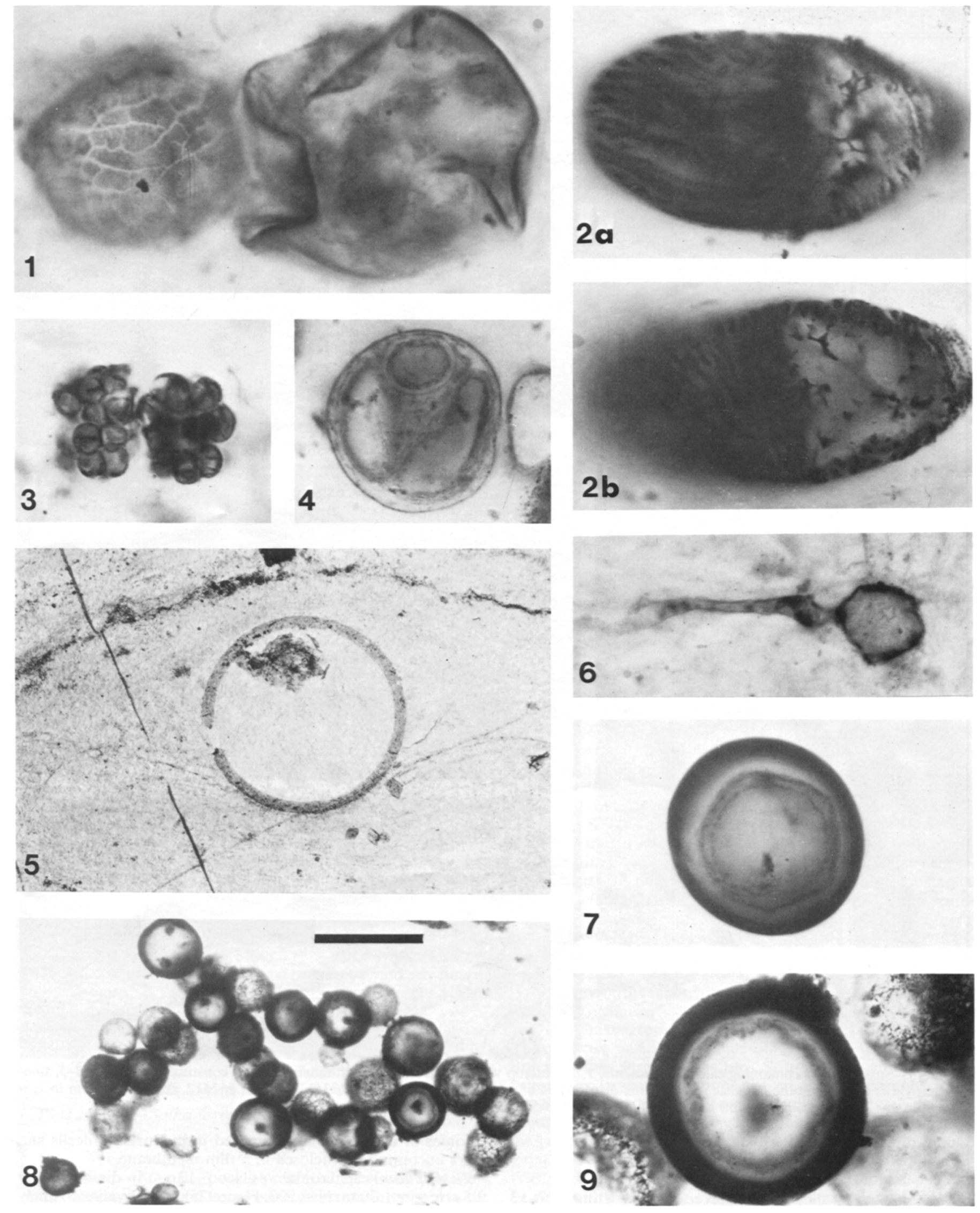

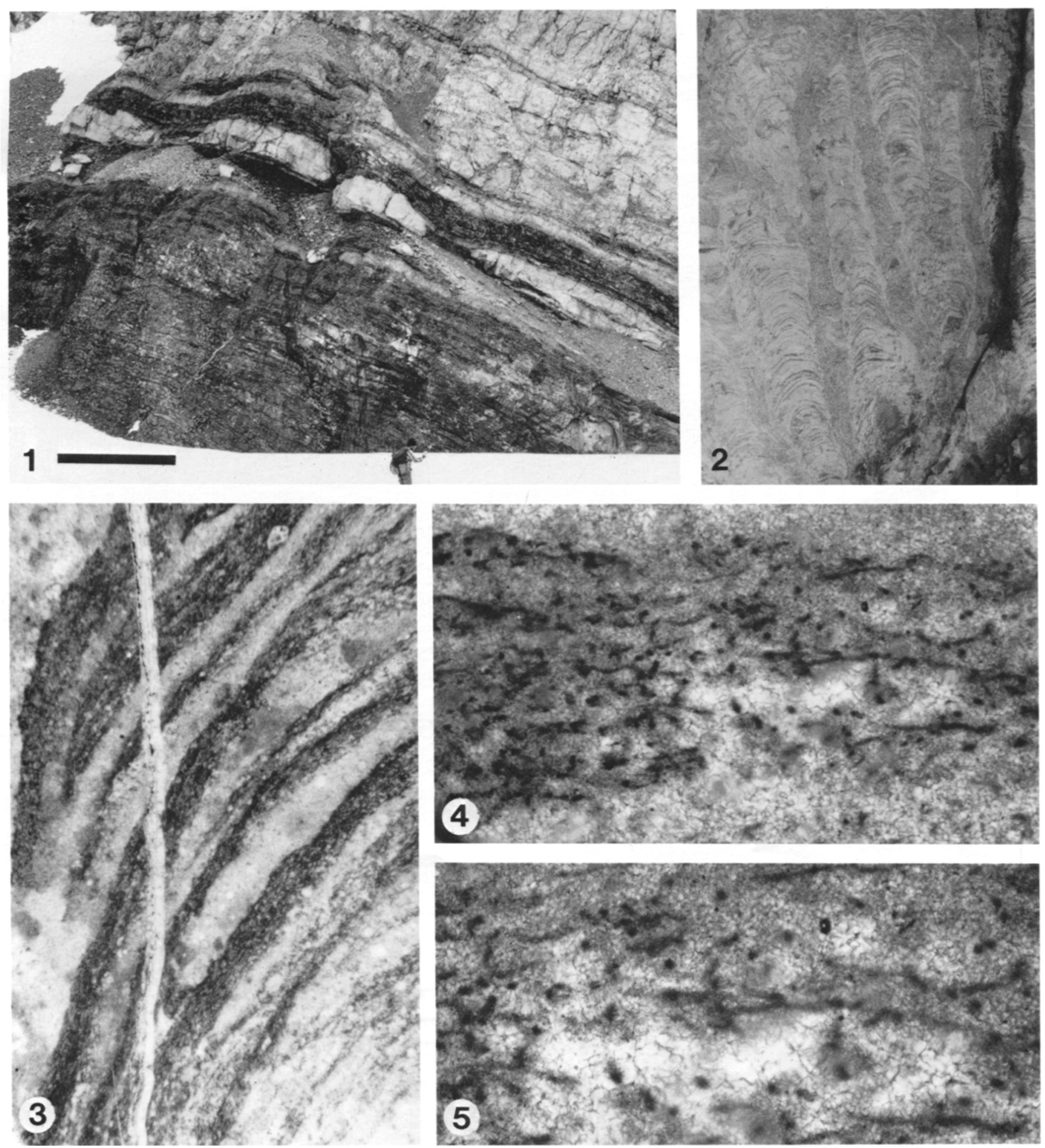

FIGURE 20-Stromatolites containing calcified filaments. 1, 2, outcrop views of stromatolitic lithoherm and its constituent columns; 3-5, thinsection views of stromatolite lamellae, showing the distribution of calcified filaments, M-4, R23/0, HUHPC \#62412. Bar in $1=20 \mathrm{~m}$ in 1 ; = $20 \mathrm{~cm}$ in $2 ;=1,000 \mu \mathrm{m}$ in $3 ;=150 \mu \mathrm{m}$ in 4 ; and $=80 \mu \mathrm{m}$ in 5 .

\section{MYXococcoIDES DISTOLA sp. nov.}

Figure 18.6-18.10

Diagnosis. - A species of Myxococcoides consisting of 7-13 $\mu \mathrm{m}$ vesicles characteristically occurring in pairs. Vesicles in loose colonies of a few to many hundred individuals. Unicells and pairs uncommonly enclosed in a thin membrane.

Description. -Spheroidal vesicles 7-13 $\mu \mathrm{m}$ in diameter $(\mathrm{x}=$ $9.5 \mu \mathrm{m} ; \mathrm{s}_{\mathrm{x}}=1.7 \mu \mathrm{m} ; \mathrm{N}=500$; Figure 25 ), walls hyaline to finely granular, ca $0.5 \mu \mathrm{m}$ thick. Vesicles occur in loose colonies of up 
to several hundred individuals. Approximately 50 percent of vesicles in colonies occur as dyads. A thin, light membrane sometimes surrounds solitary vesicles and dyads, but no more encompassing envelope or mucilage is apparent.

Etymology.-With reference to the common occurrence of dyads in this species.

Type specimen. - Under the rules of botanical nomenclature, a single specimen must serve as type, rather than a population. Thus, the specimen noted by the arrow in Figure 18.9 is designated as the type of the species. It is reposited in the Paleobotanical Collections of the Harvard University Herbaria under catalog number 62355 .

Type locality. - South face of Dracofjella nunatak along Polarisbreen glacier, Ny Friesland, Spitsbergen.

Discussion. - The characteristic presence of dyads in these fossils distinguishes them from previously described species of Myxococcoides. "Diplococcus" populations from the Neoproterozoic Yudoma Formation, Siberia, are similar if not identical (Lo, 1980). Some (but not all) of the paired spheroids illustrated by Sergeev (1988, his fig. 1L, M) from Neoproterozoic cherts in the Southern Urals also resemble $M$. distola.

\section{MyXococcoIDES STRAGULESCENS Green et al., 1989}

Discussion. - This species, distinguished by its median splits and tendency to form layers in mats, is common in East Greenland, but rare within Draken Siphonophycus inornatum mats.

\section{MYXococcoIDES sp. D}

Figure 19.7-19.9

Description. - Spheroidal vesicles $30-50 \mu \mathrm{m}$ in diameter, with thick dark walls (up to $4 \mu \mathrm{m}$ thick).

Discussion. - These thick vesicles are problematic and rare. The single cluster observed is placed in open nomenclature as a species of Myxococcoides, although the generic assignment remains in some doubt. The population is referred to as Myxococcoides sp. D to distinguish it from the three Draken Myxococcoides forms (spp. A-C) treated in open nomenclature by Knoll (1982).

\section{Genus Polytrichoides LineAtus German, 1974, emend.} Figure 4.3, 4.5

Discussion. - These nonseptate tubular filaments are distinguished from Siphonophycus by their occurrence in tightly wound groups. The Draken population consists of 3-5 $\mu \mathrm{m}$ wide tubes wound in rope-like groups of up to 12 individuals that formed mats within the upper intertidal to supratidal zone. Morphologically, but perhaps not environmentally, these populations compare closely with $P$. lineatus, originally described from shales of the Upper Riphean Mireodikha Suite, Siberia (German, 1974).

The filaments are probably the sheaths of oscillatorian cyanobacteria, although this cannot be proven beyond any doubt. Individual sheaths in the Draken populations resemble Siphonophycus inornatum and may represent a behavioral variant of this species; however, no intermediate or mixed populations were observed.

Genus SATKA Jankauskas, 1979

Type species. - Satka favosa Jankauskas, 1979.

\section{SATKA sp.}

Discussion. - A single, poorly preserved specimen belonging to this widely distributed Proterozoic genus was observed in the Draken shale assemblage.
TABLE 6-Calcified microfossils (samples M-4, P-22, and P(F)-7018).

\begin{tabular}{lcc}
\hline \multicolumn{1}{c}{ Taxon } & Size $(\mu \mathrm{m})^{1}$ & \multicolumn{1}{c}{ Comments } \\
$\begin{array}{l}\text { cf. Siphonophycus } \\
\begin{array}{l}\text { inornatum } \\
\text { cf. Polybessurus } \\
\text { bipartitus }\end{array}\end{array}$ & $4.0(0.9)$ & $\begin{array}{l}\text { Principal builder in columnar } \\
\text { stromatolites }\end{array}$ \\
\hline
\end{tabular}

' Mean and standard deviation (in parentheses) for cross-sectional diameters of fossils.

Genus SiPHONOPHYCUS Schopf, 1968, emend.

Siphonophycus SCHOPF, 1968, p. 671.

Eomycetopsis SCHOPF, 1968, p. 684.

Tenuofilum SCHOPF, 1968, p. 679.

Leiotrichoides GERMAN, 1974, p. 8-9, fig. 1, table VI.

Type species. - Siphonophycus kestron Schopf, 1968.

Diagnosis (emended). - Tubular, filamentous microfossils, nonseptate and unbranched, with little or no tapering toward filament termini; tubes truncated and open at ends or with closed, more or less hemispherical terminations; walls typically preserved as chagrenate to finely reticulate organic matter, but may be preserved as carbonate rinds.

Discussion. - In his seminal monograph on the Bitter Springs microbiota, Schopf (1968) diagnosed the genus Siphonophycus as aseptate tubes $8.3-15 \mu \mathrm{m}$ in cross-sectional diameter. Schopf recognized the occasional preservation of transverse thickenings along filaments and interpreted these fossils as the preserved extracellular sheaths of LPP-type (Rippka et al., 1979) cyanobacteria. A single species, $S$. kestron, whose diagnosis matched that of the genus, was described. Eomycetopsis was erected for tubular filaments that differed from Siphonophycus in being smaller (2-4.5 $\mu \mathrm{m}$ in cross-sectional diameter) and rarely interrupted by septa. Two species were described and interpreted as possible fungal hyphae. Tenuofilum, in turn, was described as a monotypic genus of small (ca $1 \mu \mathrm{m})$, uniseriate trichomes with often inconspicuous septa and no sheaths.

Subsequent research showed that the type specimens and associated populations of Siphonophycus kestron, Eomycetopsis robusta, and Tenuofilum septatum are all aseptate filamentous tubes that differ principally in size (Hofmann, 1976; Knoll, 1981). (As noted by Knoll (1982), Tenuofilum septatum specimens figured in Schopf and Blacic (1971) are clearly trichomes and should be transferred to the genus Cephalophytarion.) The populations differ quantitatively (i.e., in size) rather than qualitatively; thus, we follow convention in classical cyanobacterial taxonomy (e.g., Geitler, 1930-1932) and view the three forms as distinct species within a single (form) genus. We have therefore placed the three genera in synonymy as Siphonophycus and recognize three species of this genus $-S$. kestron, $S$. robustum, and $S$. septatum-in the Bitter Springs Formation. Pjatiletov (1988) previously synonymized Leiotrichoides German (1974) with Eomycetopsis; we include these fossils in Siphonophycus as well. Draken rocks contain five distinct size classes of $\mathrm{Si}$ phonophycus, and these populations are assigned to the three Bitter Springs form species plus $S$. inornatum and $S$. capitaneum. The larger populations are presumably cyanobacterial, but $S$. septatum and $S$. robustum could alternatively be flexibacterial in origin (e.g., Aizenshtat et al., 1984). For this reason, the genus is classified as incertae sedis rather than cyanobacterial. It is important to remember that the species of Siphonophycus are form species, and that interbasinal comparisons may be suspect; many living cyanobacterial species have morphologies that would converge taphonomically on these fossils. 

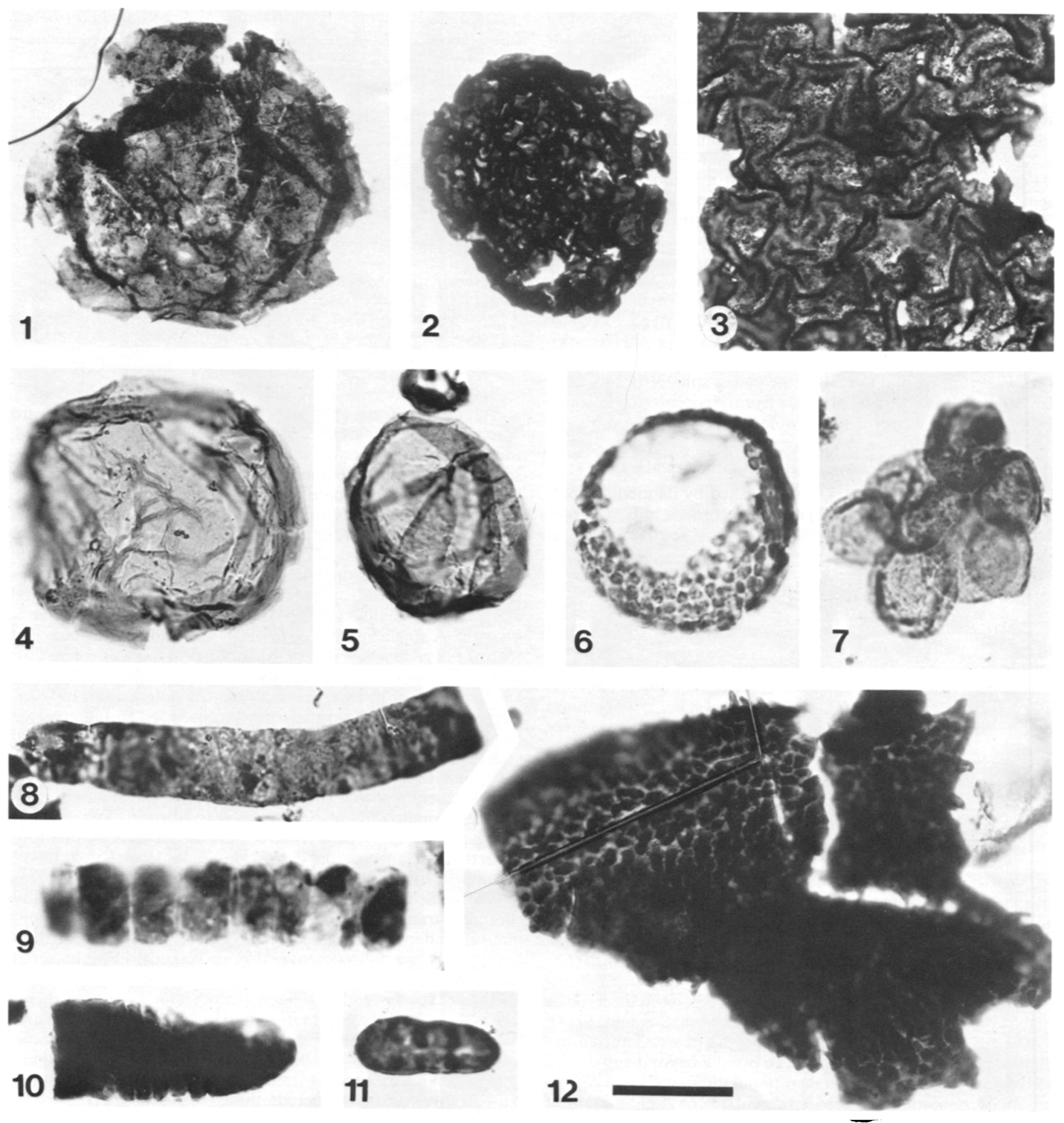

FIGURE 21-Shale facies microfossils. 1, Leiosphaeridia jacutica, P-23-10, N42/0, HUHPC \#62413; 2, Leiosphaeridia sp. cf. L. atava, P-23-10, M37-3, HUHPC \#62414; 3, detail of $L$. sp. cf. $L$. atava fragment showing characteristic wrinkling pattern, P-23-1, F31/1, HUHPC \#62415; 4, 5, Leiosphaeridia crassa; 4, P-23-9, V53/2, HUHPC \#62416; 5, P-23-7, K22/8, HUHPC \#62417; 6, Leiosphaeridia sp., P-23-5, H45/0, HUHPC \#62418; 7, Myxococcoides sp., P-23-9, M34/3, HUHPC \#62419; 8, filamentous sheath, P-23-1, E33/0, HUHPC \#62420; 9, 10, trichome fragments; 9, P-23-11, J33/1, HUHPC \#62421; 10, P-23-5, R59/2, HUHPC \#62422; 11, Gloeodiniopsis mikros, P-23-6, M54/3, HUHPC \#62423; 12, Gorgonisphaeridium maximum, P-23-6, J35/3, HUHPC \#62424. Bar in $12=85 \mu \mathrm{m}$ in $1-3 ;=20 \mu \mathrm{m}$ in 4-7, 9, 10, and 12 ; and $=10 \mu \mathrm{m}$ in 8 and 11 . 
TABLE 7-Taxa present in subtidal shale assemblage (sample P-23).

\begin{tabular}{|c|c|c|}
\hline Taxon & Size $(\mu \mathrm{m})^{1}$ & Comments \\
\hline $\begin{array}{l}\text { Myxococcoides } \\
\text { cantabrigiensis }\end{array}$ & $9.0-19.0$ & Probable phytoplankton \\
\hline $\begin{array}{l}\text { Leiosphaeridia crassa } \\
\text { Trachyhystricho- } \\
\text { sphaera vidalii }\end{array}$ & $\begin{array}{l}25.0-80.0 \\
(2)\end{array}$ & $\begin{array}{l}\text { Probable phytoplankton } \\
\text { Fragments; probable } \\
\text { phytoplankton }\end{array}$ \\
\hline $\begin{array}{l}\text { Leiosphaeridia jacutica } \\
\text { Leiosphaeridia sp. cf. } \\
\text { L. atava }\end{array}$ & $\begin{array}{l}150-300 \\
200-260\end{array}$ & $\begin{array}{l}\text { Probable phytoplankton } \\
\text { Probable phytoplankton }\end{array}$ \\
\hline $\begin{array}{l}\text { Stictosphaerdium sp. } \\
\text { Gorgonisphaeridium } \\
\text { maximum }\end{array}$ & $\begin{array}{l}15.0-30.0 \\
>150\end{array}$ & $\begin{array}{l}\text { Probable phytoplankton } \\
\text { Single specimen; possible } \\
\text { phytoplankton }\end{array}$ \\
\hline $\begin{array}{l}\text { Satka sp. } \\
\text { cf. Gloeodiniopsis } \\
\text { mikros }\end{array}$ & $\begin{array}{l}(2) \\
6.0-8.0\end{array}$ & $\begin{array}{l}\text { Rare in assemblage } \\
\text { Rare; possibly allochtho- } \\
\text { nous, originating on tidal } \\
\text { flat }\end{array}$ \\
\hline Siphonophycus spp. & $2.0-25.0$ & $\begin{array}{l}\text { Fragments; probably } \\
\text { allochthonous }\end{array}$ \\
\hline Trichome fragments $^{3}$ & $2.9-19.0$ & $\begin{array}{l}\text { Fragments; probably } \\
\text { allochthonous }\end{array}$ \\
\hline
\end{tabular}

' Observed range for maximum diameter (cross-sectional diameter of filamentous fossils).

${ }^{2}$ Specimens generally incomplete.

${ }^{3}$ Possibly includes several species.

\section{SiPHONOPHYCUS CAPITANEUM Nyberg and Schopf, 1984 Figure 3.4}

Discussion. - These large (up to $25 \mu \mathrm{m}$ in cross-sectional diameter) tubes occur as auxiliary builders in some upper intertidal to supratidal mats.

\section{SIPHONOPHYCUS ROBUSTUM cOmb. nOV.}

Figure 10.3, 10.5

Eomycetopsis robusta SCHOPF, 1968, p. 685, Pl. 82, figs. 2, 3, Pl. 83, figs. 1-4; KNOLl AND GolUBiC, 1979, p. 149, fig. 4A, B.

Eomycetopsis filiformis SCHOPF, 1968, p. 685, P1. 82, figs. 1, 4, Pl. 83, figs. 5-8.

Discussion. -Consistent with the genus-level synonymy presented above, this species is transferred to Siphonophycus, and the specific epithet is accordingly changed to robustum.

Draken populations occur as auxiliary builders in $S$. septatum mats, as occasional microbenths in vertical tube-dominated lagoonal carbonates, and as oncoid and thin mat-builders on the inner flanks of oolitic shoals.
TABLE 8-Taxa present in the oncolitic assemblage (samples P-28, P-97, P-4665)

\begin{tabular}{lcl}
\hline \hline \multicolumn{1}{c}{ Taxon } & $\begin{array}{c}\text { Size } \\
(\mu \mathrm{m})^{1}\end{array}$ & Comments \\
\hline $\begin{array}{l}\text { Siphonophycus robustum } \\
\text { Trachyhystrichosphaera vidalii }\end{array}$ & $2-4$ & Oncoid builder \\
Allochthonous
\end{tabular}

' Footnote here????

SIPHONOPHYCUS SEPTATUM comb. nov. Figure 10.2

Tenuofilum septatum SCHOPF, 1968, p. 679, Pl. 86, figs. 10-12. not Tenuofilum septatum Schopf. ScHOPf AND BLACIC, 1971, Pl. 108, figs. 11,13 .

Discussion. - The generic synonymy of Tenuofilum with $\mathrm{Si}$ phonophycus necessitates this new combination.

Draken populations occur mainly as principal mat-builders in lower intertidal to transitional intertidal/subtidal mats.

\section{Genus StictosPhaERIDIUM Timofeev, 1966, emend. Mikhailova and Jankauskas in Jankauskas, 1989}

Type species. - Stictosphaeridium sinapticuliferum Timofeev, 1966, emend. Mikhailova and Jankauskas in Jankauskas, 1989.

\section{STICTOSPHAERIDIUM $\mathrm{sp}$.}

Discussion. - Small (ca $20 \mu \mathrm{m}$ ), very thin-walled, chagrenate vesicles occur as a minor constituent of the Draken shale assemblage. These vesicles are similar to Stictosphaeridium populations described widely from Neoproterozoic shales (Timofeev, 1966; Vidal, 1976; Jankauskas, 1989).

\section{Vertical tubes}

Figure 5.1-5.3, 5.6

Description. - Vertically oriented, sparsely branched filaments $13-59 \mu \mathrm{m}$ in cross-sectional diameter $\left(\bar{x}=24 \mu \mathrm{m} ; \mathrm{s}_{\mathrm{x}}=\right.$ $8 \mu \mathrm{m} ; \mathrm{N}=125$ ). Filaments preserved as siliceous or dolomitic internal molds, and no organic walls observed; thus, no information available on possible organization of cells or sheaths within individuals.

Discussion. - Vertical tubes occur within fine-grained lagoonal carbonates. As noted in the text, their taxonomic relationships are unknown; possible affinities include, but are not limited to, scytonematacean cyanobacteria and cladophoralean green algae.

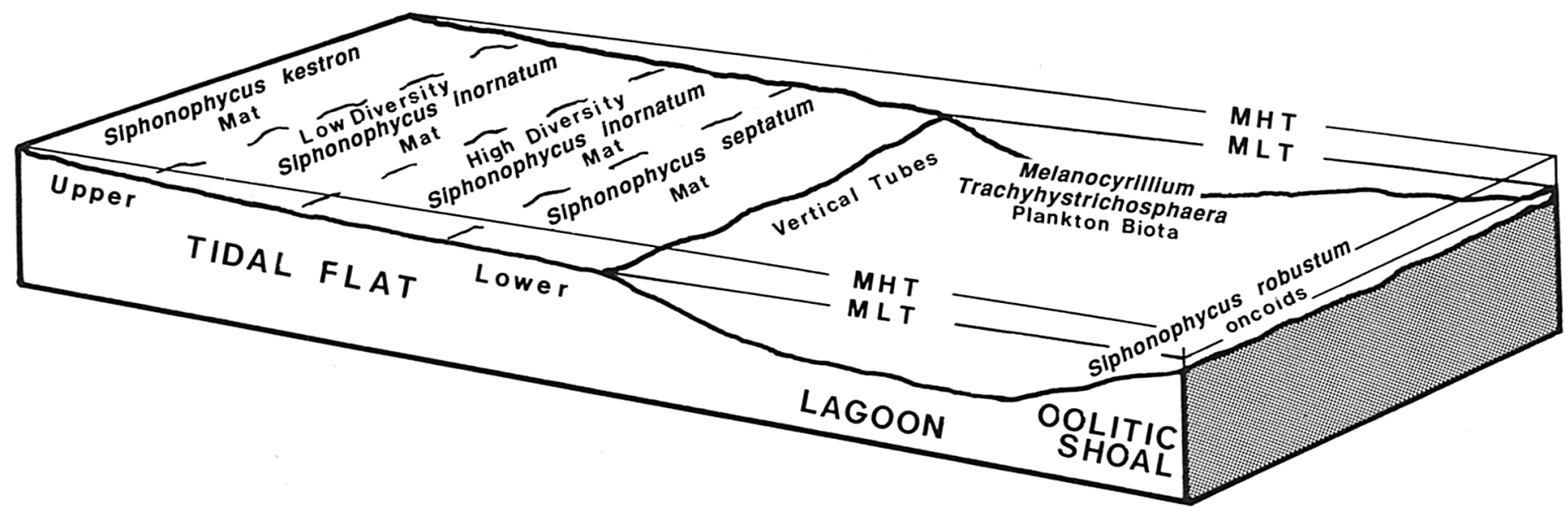

FIGURE 22-Diagram illustrating the distribution of the principal biofacies in the Draken tidal flat/lagoonal complex. 


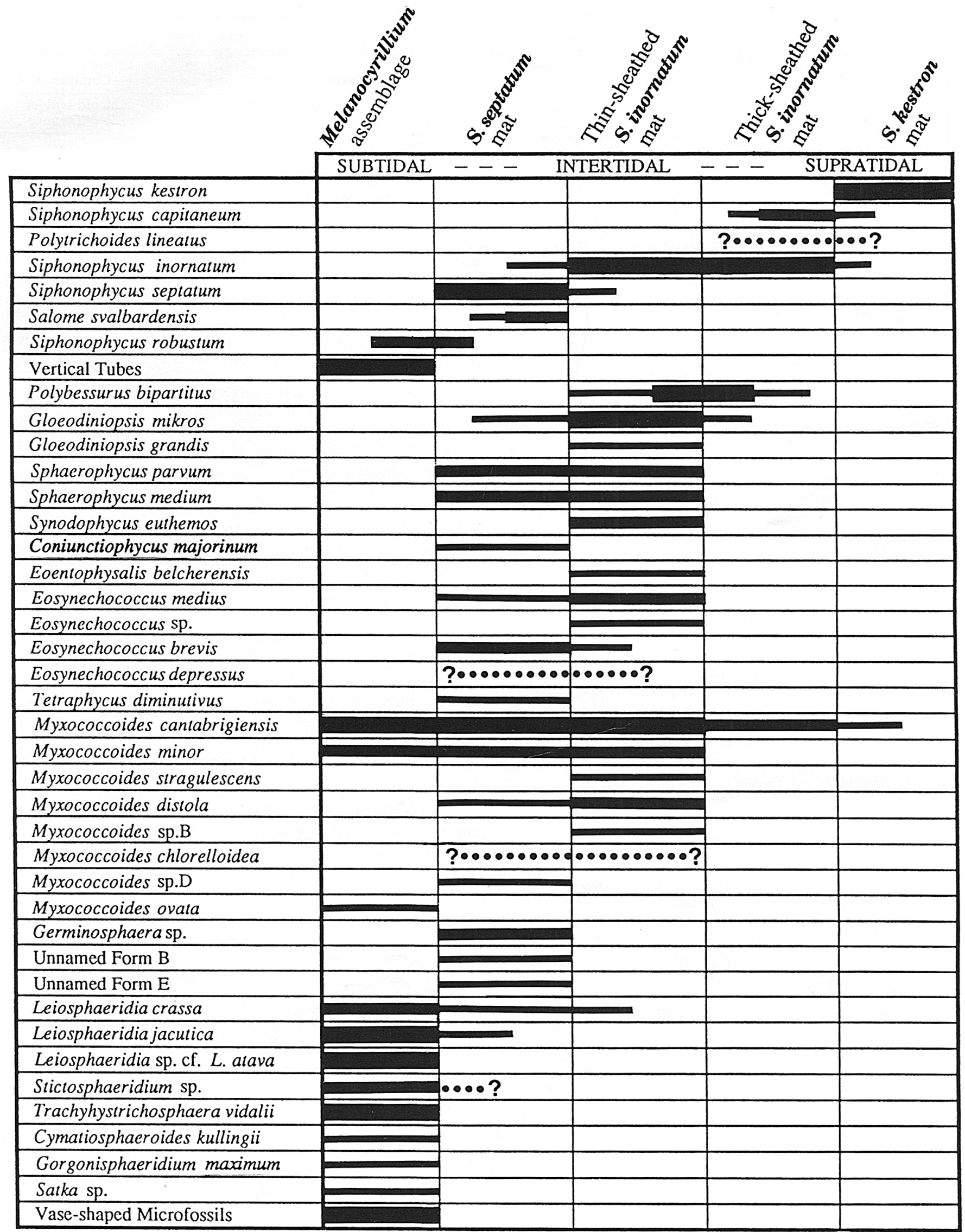

FIGURE 23-Distribution of species among biofacies in the Draken tidal flat/lagoonal complex. 
TABLE 9-Principal biofacies in the Draken Conglomerate Formation.

1. Melanocyrillium Biofacies

2. Siphonophycus septatum Biofacies

3. Thin-walled Siphonophycus inornatum Biofacies

4. Thick-walled Siphonophycus inornatum Biofacies

5. Siphonophycus kestron Biofacies a. Characterized by vase-shaped microfossils (Melanocyrillium spp.) and vertically oriented filaments, preserved as molds; large, process-bearing acritarchs; leiosphaerid acritarchs; and Myxococcoides spp.

b. Subtidal, lagoonal

a. Principal mat-builder, S. septatum; auxiliary mat-builder, Salome svalbardensis; diverse dweller taxa; common allochthonous fossils, including some Myxococcoides spp.

b. Lower intertidal or transitional lagoonal margin/lower intertidal zone

a. Principal mat-builder, $S$. inornatum characterized by thin sheaths; diverse dweller taxa; common allochthonous Myxococcoides spp.

b. Lower intertidal zone

a. Principal mat-builder, $S$. inornatum with thick sheaths; auxiliary mat-builder in more exposed areas, Siphonophycus capitaneum; dwellers rare; allochthonous elements uncommon

b. Upper intertidal zone

a. Mat-builder, S. kestron; mat-dweller and allochthonous elements rare or absent

b. Upper intertidal to supratidal zone

Although the five biofacies tabulated above collectively account for more than 90 percent of all Draken microfossils, other assemblages occur in the formation:

1. Siphonophycus robustum and rare other fossils preserved in the crescentic laminae of oncoids formed in subtidal environments subject to episodic wave or current action.

2. Calcified Lyngbya/Phormidium-type filaments in subtidal columnar stromatolites.

3. Leiosphaerid and large, process-bearing acritarchs; Myxococcoides spp.; and fragments trichomes and sheaths in siliciclastic silstone. This assemblage compares closely with that of the carbonate-associated Melanocyrillium biofacies.

4. Calcified Polybessurus bipartitus populations that form crusts locally in the upper intertidal to supratidal zone. Correlative beds from central East Greenland contain silicified Polybessurus crusts that are clearly nestled within Siphonophycus inornatum mats.

\section{Unnamed form $\mathrm{E}$}

Figure 6.5

Description. - A single fusiform specimen $120 \mu \mathrm{m}$ long and $75 \mu \mathrm{m}$ wide. Thin, multilamellate outer walls; thick, dense, somewhat diffluent interior "wall"; granular internal layer approximately $1 \mu \mathrm{m}$ thick, $70 \mu \mathrm{m}$ in maximum diameter, and 37 $\mu \mathrm{m}$ across; and granular internal body $15 \mu \mathrm{m}$ in diameter.

Discussion. - This is a solitary form observed once within a shard of Siphonophycus septatum mat. It is illustrative of the rare problematica that increase the species richness of Draken cherts. The designation "unnamed form E" distinguishes this fossil from Draken specimens described informally by Knoll (1982).

\section{ACKNOWLEDGMENTS}

A portion of this paper is based on a senior thesis submitted to Harvard College by J. M. We thank W. B. Harland and M. Hambrey for making available Draken samples collected by $\mathrm{C}$. B. Wilson and T. Jefferson; N. Butterfield for help in palynological preparation; D. Cullinane for technical assistance; and I. Fairchild, S. Golubic, R. Buick, and N. Butterfield for helpful discussions. Draken field work was supported by NSF grants DPP 80-19998 and DPP 85-18563; laboratory studies were supported in part by NASA Grant NAGW 863.

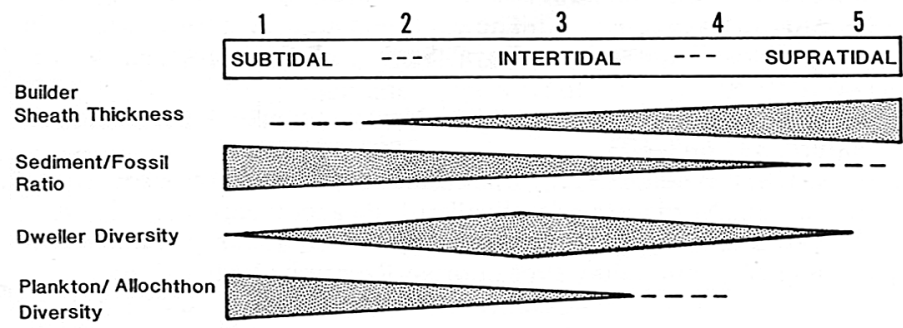

FIGURE 24-Paleoecological trends among biofacies in the Draken tidal flat/lagoonal complex. Biofacies numbers 1-5 correspond to the $\mathrm{Me}$ lanocyrillium, Siphonophycus septatum, thin-sheathed $S$. inornatum, thick-sheathed $S$. inornatum, and $S$. kestron biofacies, respectively.

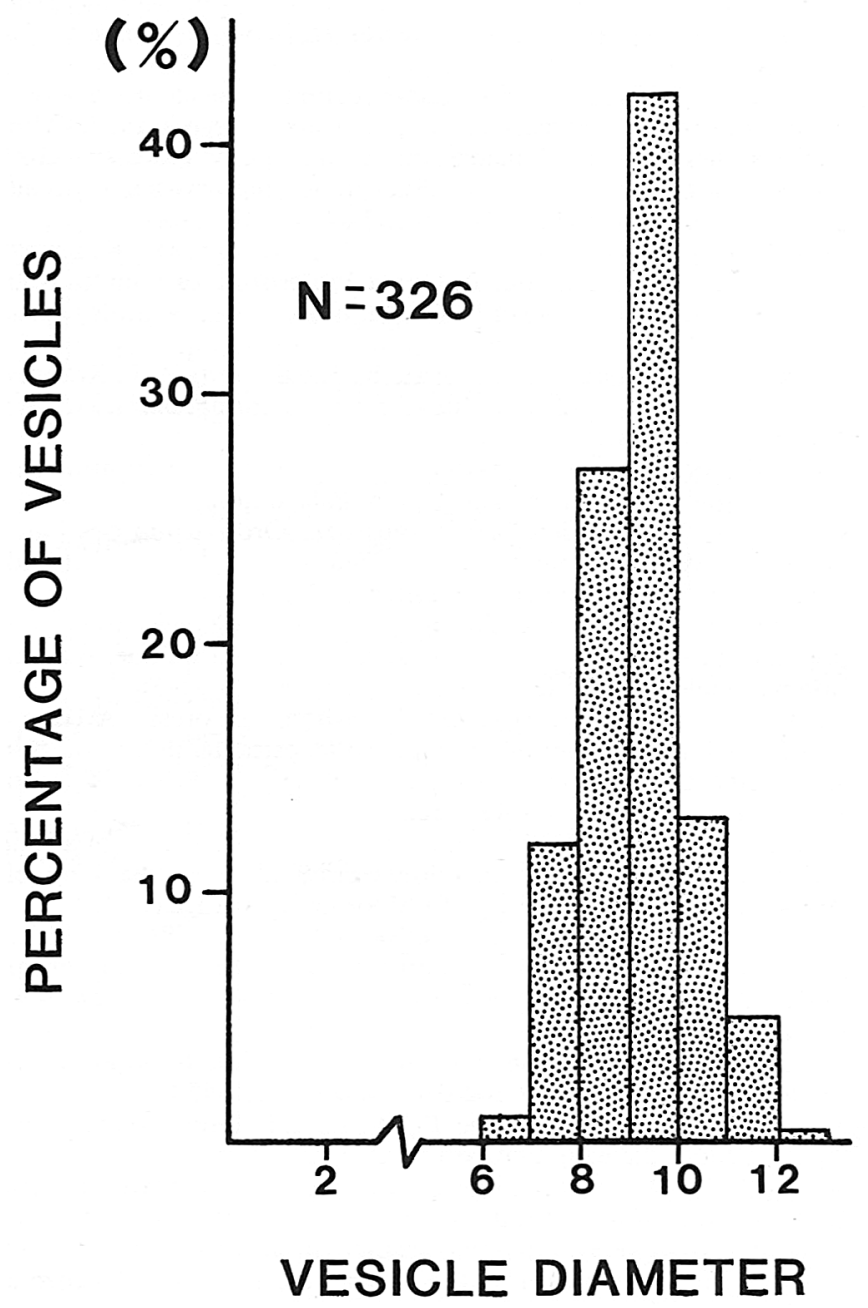

FIGURE 25-Size frequency distribution for a sample population of Myxococcoides distola. 


\section{REFERENCES}

ArTKEN, J. D. 1989. Giant "algal" reefs, Middle/Upper Proterozoic Little Dal Group (>770, <1200 Ma), Mackenzie Mountains, N.W.T., Canada, p. 13-23. In H. H. J. Geldsetzer, N. P. James, and G. E. Tebbutt (eds.), Reefs: Canada and Adjacent Areas. Canadian Society of Petroleum Geologists Memoir 13.

Alzenshtat, Z., G. LIPINER, AND Y. Cohen. 1984. Biogeochemistry of carbon and sulfur in the microbial mats of the Solar Lake (Sinai), p. 281-312. In Y. Cohen, R. W. Castenholz, and H. O. Halvorson (eds.), Microbial Mats: Stromatolites. Alan R. Liss, New York.

Aluison, C. W., AND S. M. AWramik. 1989. Organic-walled microfossils from earliest Cambrian or latest Proterozoic Tindir Group rocks, northwest Canada. Precambrian Research, 43:253-294.

Atkinson, A. W., B. E. S. Gunning, AND P. C. L. JoHn. 1972. Sporopollenin in the cell wall of Chlorella and other algae: ultrastructure, chemistry, and incorporation of ${ }^{14} \mathrm{C}$-acetate. Planta, 107:1-32.

BARghOORN, E. S., AND S. A. TYler. 1965. Microorganisms from the Gunflint chert. Science, 147:563-577.

BAULD, J. 1981. Geobiological role of cyanobacterial mats in sedimentary environments: production and preservation of organic matter. BMR Journal of Australian Geology and Geophysics, 6:307-317.

- 1986. Benthic microbial communities of Australian saline lakes, p. 95-111. In P. de Deckker and W. D. Williams (eds.), Limnology in Australia. Dr. J. Junk, The Hague.

BEHRENSMEYER, A. K., AND S. M. KIDWELl. 1985. Taphonomy's contributions to paleobiology. Paleobiology, 11:105-119.

BLACK, M. 1933. The algal sediments of Andros Island, Bahamas. Philosophical Transactions, Royal Society, London, B222:165-192.

BUTTERFIELD, N. J. 1990. Organic preservation of non-mineralizing organisms and the taphonomy of the Burgess Shale. Paleobiology, 16: 272-286.

- AND A. H. KNOLL. 1989. Large, complex acritarchs in Upper Proterozoic rocks. Abstracts, Geological Association of Canada-Mineralogical Association of Canada, Annual Meeting, Montreal, p. A100.

- , AND K. SwETT. 1988. Exceptional preservation of fossils in Upper Proterozoic shale. Nature, 334:424-427.

DerRy, L. A., L. S. Keto, S. B. JACOBSEN, A. H. KNOll, AND K. SWetT. 1989. Sr isotopic variations in Upper Proterozoic carbonates from Svalbard and East Greenland. Geochimica et Cosmochimica Acta, 53:2331-2339.

Dill, R. F., E. A. Shinn, A. T. Jones, K. Kelly, and R. P. Steinen. 1986. Giant subtidal stromatolites forming in normal salinity waters. Nature, 324:55-58.

DOWNIE, C., AND W. A. S. SARJEANT. 1963. On the interpretation and status of some Hystrichosphere genera. Palaeontology, 6:83-96.

EisEnACK, A. 1958. Microfossilien aus dem Ordovizium des Baltikums. 1. Markasitschicht, Dictyonema-Schiefer, Glaukonitsand, Glaukonitkalk. Senckenbergiana Lethaea, 39:389-404.

ErCEgovic, A. 1932. Etudes écologiques et sociologiques des Cyanophycées lithophytes de la côte Yougoslave de l'Adriatique. Bulletin Internationale, Academie Yougoslave Sciences, 26:33-56.

FAIRChILD, I. J., A. H. KNOLL, AND K. SWETT. In press. A coastal lithofacies-biofacies continuum with syndepositional dolomitization and silicification (Draken Conglomerate Formation, Upper Riphean, Spitsbergen). Precambrian Research.

FAIRCHILD, T. 1975. The geologic setting and paleobiology of a Late Precambrian stromatolitic microflora from South Australia. Unpubl. Ph.D. dissertation, University of California, Los Angeles, 272 p.

Francis, S., L. Margulis, AND E. S. BarghOORN. 1978. On the experimental silicification of microorganisms. II. On the time of appearance of eukaryotic organisms in the fossil record. Precambrian Research, 6:65-100.

Gertler, L. 1925. Cyanophyceae. A. Pascher's Die Süsswasserflora Deutschlands, Osterreichs, und der Schweiz, 12:1-450.

- 1930-1932. Cyanophyceae. Band 14, Dr. L. Rabenhorst's Kryptogamen-Flora. Leipzig, 1197 p.

GermaN, T. 1974. Nakhodi massevikh skoplyennii trikhomov v Rifeyi. Microphytofossilii Proterozoya i Rannyogo Paleozoya SSSR, $p$. 6-10. [The discovery of massive accumulations of trichomes in the Riphean. Microphytofossils of the Proterozoic and Lower Paleozoic, USSR, p. 6-10.]

- 1981. Nitchatye mikroorganizmy lakhandinskoj svity reki Mai
[Filamentous microorganisms from the Lakhanda Suite along the River Maya]. Paleontologicheskiy Zhurnal, 1981:126-131.

GoluBic, S. 1976. Organisms that build stromatolites, p. 113-126. In M. R. Walter (ed.), Stromatolites. Elsevier, Amsterdam.

, AND E. S. BARGHOORN. 1977. Interpretation of microfossils with special reference to the Precambrian, p. 1-14. In E. Flügel (ed.), Fossil Algae. Springer Verlag, Heidelberg.

, AND H. J. HoFmanN. 1976. Comparison of Holocene and midPrecambrian Entophysalidaceae (Cyanophyta) in stromatolitic algal mats: cells division and degradation. Journal of Paleontology, 50: 1074-1082.

Green, J. W., A. H. Knoll, S. Golubic, And K. Swett. 1987. Paleobiology of distinctive benthic microfossils from the Upper Proterozoic Limestone-Dolomite 'Series', central East Greenland. American Journal of Botany, 62:835-852.

,-- AND K. SWETT. 1988. Microfossils in oolites and pisolites from the Upper Proterozoic Eleonore Bay Group, central East Greenland. Journal of Paleontology, 62:835-852.

,,- AND - 1989. Microfossils from silicified stromatolitic carbonates of the Upper Proterozoic Limestone-Dolomite 'Series', central East Greenland. Geological Magazine, 126:567-585.

HAMBreY, M. J. 1982. Late Precambrian diamictites of northeastern Svalbard. Geological Magazine, 119:527-551.

HARDIE, L. A. (ed.). 1977. Sedimentation on the Modern Carbonate Tidal Flats of Northwest Andros Island, Bahamas. The Johns Hopkins University Studies in Geology 22, 202 p.

HARLAND, W. B., AND N. J. R. WRIGHT. 1979. Alternative hypothesis for the pre-Carboniferous evolution of Svalbard. Norsk Polar Institutt Skrifter, 167:89-117.

HofmanN, H. J. 1976. Precambrian microflora, Belcher Islands, Canada: significance and systematics. Journal of Paleontology, 50:1040 1073.

HorodysKi, R. J., AND J. A. Donaldson. 1980. Microfossils from the Middle Proterozoic Dismal Lakes Group, arctic Canada. Precambrian Research, 11:125-159.

, AND S. VONDER HAAR. 1975. Recent calcareous stromatolites from Laguna Mormona (Baja California) Mexico. Journal of Sedimentary Petrology, 45:894-906.

JANKAUSKAS, T. V. 1979. Nizhnyerifeyiskii mikrobioti Yzhnogo Urala [Lower Riphean microfossils of the Southern Urals]. Doklady, Akademii Nauk SSSR, 247:1465-1467.

- 1982. Mikrofossilii Rifeya Yzhnogo Urala [Riphean microfossils from the Southern Urals], p. 84-120. In B. M. Keller (ed.), Stratotyp Rifeya: Paleontologiya ee Paleomagnetizm [Stratotype of the Riphean: Paleontology and Paleomagnetics]. Trudy Geologicheskii Institut, SSSR Akademyii Nauk, Moscow.

(ed.). 1989. Mikrofossilii Dokembriya SSSR [Precambrian Microfossils of the USSR]. Trudy Institut Geologii ee Geokhronologii SSSR Akademii Nauk, Leningrad, $188 \mathrm{p}$.

Johnson, J. L. 1961. Limestone-building Algae and Algal Limestones. Colorado School of Mines, Golden, 297 p.

Knoll, A. H. 1981. Paleoecology of late Precambrian microbial assemblages, p. 17-54. In N. J. Niklas (ed.), Paleobotany, Paleoecology, and Evolution, Volume 1. New York, Praeger.

- 1982. Microorganisms from the late Precambrian Draken Conglomerate Formation, Ny Friesland, Spitsbergen. Journal of Paleontology, 56:755-790.

. 1984. Microbiotas of the late Precambrian Hunnberg Formation, Nordaustlandet, Svalbard. Journal of Paleontology, 58:131-162.

-, AND J. BAULD. 1989. The evolution of ecological tolerance in prokaryotes. Transactions, Royal Society of Edinburgh, Earth Sciences, 80:209-223.

- AND N. J. ButTERFIELD. 1989. New window on Proterozoic life Nature, 337:602-603.

, AND S. CALDER. 1983. Microbiotas of the late Proterozoic Ryssö Formation, Nordaustlandet, Svalbard. Palaeontology, 26:467-496.

, AND S. Golubic. 1979. Anatomy and taphonomy of a Precambrian algal stromatolite. Precambrian Research, 10:110-151.

, J. M. Hayes, J. Kaufman, K. Swet, ANd I. Lambert. 1986. Secular variation in carbon isotope ratios from Upper Proterozoic successions of Svalbard and East Greenland. Nature, 321:832-838. , AND K. SWETT. 1985. Micropaleontology of the Late Proterozoic Veteranen Group, Spitsbergen. Palaeontology, 28:451-473. 
- AND - 1990. Carbonate deposition during the Late Proterozoic Era: an example from Spitsbergen. American Journal of Science, 290A:104-132.

,,-- AND E. BURKHARDT. 1989. Paleoenvironmental distribution of microfossils and stromatolites in the Upper Proterozoic Backlundtoppen Formation, Spitsbergen. Journal of Paleontology, 63:129145.

KomAR, V. 1979. Klassifikatsia stromatolitov po mikrostrukturam [The classification of stromatolites by microstructure], p. 42-45. In B. V. Sokolov (ed.), Paleontologia Dokembriya i Rannyevo Kembriya [Paleontology of the Precambrian and Lower Cambrian]. Trudy, Institut Geologii i Geokhronologii Dokembriya, Akademii Nauk SSSR, Leningrad.

KomareK, J., AND K. ANAGnOSTIDIS. 1986. Modern approach to the classification system of cyanophytes. Archiv für Hydrobiologie, Supplement to 73(2):157-226.

LICARI, G. R. 1978. Biogeology of the late pre-Phanerozoic Beck Spring Dolomite of eastern California. Journal of Paleontology, 52:767-792.

Lo, S.-C. C. 1980. Microbial fossils from the lower Yudoma Suite, earliest Phanerozoic, eastern Siberia. Precambrian Research, 13:109166.

Maliva, R. G., A. H. KNoll, AND R. Siever. 1989. Secular change in chert distribution: a reflection of evolving biological participation in the silica cycle. Palaios, 4:519-532.

Mendelson, C. V., AND J. W. SCHOPF. 1982. Proterozoic microfossils from the Sukhaya Tunguska, Shorikha,and Yudoma Formations of the Siberian Platform, USSR. Journal of Paleontology, 56:42-83.

Mikhailova, N. S. 1986. Noviye nakhodki mikrophytofossilii iz otlozhyenii vekhogo rifeya Krasnoyarskogo kraya [New discoveries of microphytofossils from Upper Riphean sediments, Krasnoyarskog region]. Aktualniye voprosi sovryemennoi paleoalgologii [Topical Problems in Contemporary Paleoalgology], Kiev, p. 31-37.

MoNTY, C. L. V. 1967. Distribution and structure of Recent stromatolitic algal mats, eastern Andros Island, Bahamas. Annales de la Société Géologique de Belgique, 90:55-100.

MUIR, M. D., AND W. A. S. SARJEANT. 1971. Bibliographie commentée des Tasmanacées et de formes vivantes apparentés (Algues: Prasinophyceae), p. 51-117. In S. Jardine (ed.), Microfossiles organiques du Paleozoique, 3, les Acritarches. Editions du CNRS, Paris.

NÄGELI, C. 1849. Gattungen einzellinger Algen, physiologisch und systematisch bearbeitet. Neue Denkschriften der Allgemeinen schweizerischen Gesellschaft für die gesamten Naturwissenschaften, 8:44-60.

NYBERG, A. V., AND J. W. SChOPF. 1984. Microfossils in stromatolitic cherts from the Upper Proterozoic Min'yar Formation, southern Ural Mountains, USSR. Journal of Paleontology, 58:738-772.

PiA, J. 1927. Thallophyta, p. 31-136. In M. Hirmer (ed.), Handbuch der Paläobotanik. Oldenbourg, Munich.

PiCketT-HeAPS, J. D. 1975. Green Algae: Structure, Reproduction, and Evolution in Selected Genera. Sinauer, Sunderland, Massachusetts, $606 \mathrm{p}$.

PJATIletov, V. G. 1988. Mikrophytofossilii pozdnyeto dokembriya Uchuro-Maiskogo raiona [Later Precambrian microphytofossils from the Uchuro-Maya Uplift], p. 47-104. In V. V. Khomentovsky (ed.), Pozdnii dokembrii i rannii paleozoi Sibiri [Later Precambrian and Early Paleozoic of Siberia: Riphean and Vendian]. Trudy, Sibirskoye Otdelyeniye Institut Geologii i Geofysiki, Akademii Nauk SSSR, Novosibirsk.

RAABEN, M. YE. 1969. Stromatoliti verkhego rifeya (Gymnosolenidi) [Upper Riphean Stromatolites (Gymnosolęnida)]. Trudy, Institut Geologii, Akademii Nauk SSSR, Moscow, 100 p.

RIDING, R. 1979 . Origin and diagenesis of lacustrine algal bioherms at the margin of the Ries crater, Upper Miocene, southern Germany. Sedimentology, 26:645-680.

- 1982. Cyanophyte calcification and changes in ocean chemistry. Nature, 299:814-815.

RippKa, R., J. Deuelles, J. B. Waterbury, M. Herdman, AND R. Y. STANIER. 1979. Generic assignments, strain histories, and properties of pure cultures of cyanobacteria. Journal of General Microbiology, $111: 1-61$.

Round, F. E. 1981. The Ecology of Algae. Cambridge University Press, Cambridge, 653 p.

SCHIEBER, J. 1989. Facies and origin of shales from the mid-Protero- zoic Newland Formation, Belt Supergroup, Montana, USA. Sedimentology, 36:203-219.

SCHOPF, J. W. 1968. Microflora of the Bitter Springs Formation, Late Precambrian, Central Australia. Journal of Paleontology, 42:651-688.

, AND J. M. BLACIC. 1971. New microorganisms from the Bitter Springs Formation (Late Precambrian) of the north-central Amadeus Basin, central Australia. Journal of Paleontology, 45:925-960.

SERGEEv, V. N. 1984. Mikrofossilii v okryemnistikh stolochatikh stromatolitakh verkhego rifeya Turukhanskogo raiona [Microfossils in Upper Riphean silicified columnar stromatolites from the Turukhansk area]. Doklady Akademii Nauk SSSR, 278:436-439.

- 1988. Okryemnenniye mikrofossili v stratotipe sryednego rifeya na yuzhom Urale [Silicified microfossils from the stratotype of the Middle Riphean, southern Urals]. Doklady Akademii Nauk SSSR, 303:708-710.

, AND I. N. KRYLOV. 1986. Mikrofossilii minyarskoi sviti Urala [Microfossils of the Min'yar Suite, Urals]. Paleontologichesky Zhurnal, 1986:84-95.

SOUTHGATE, P. N. 1986. Despositional environment and mechanism of preservation of microfossils, upper Proterozoic Bitter Springs Formation, Australia. Geology, 14:683-686.

Stanier, R. Y., W. R. Sistrom, T. A. Hansen, B. A. Whitron, R. W. Castenholz, N. Pfenni, V. N. Gorlenko, E. N. Kondratieva, K. E. EImhjellen, R. Whittendiry, R. L. GHeRNA, AND H. G. TrüPer. 1978. Proposal to place nomenclature of the Cyanobacteria (bluegreen algae) under the rules of the International Code of Nomenclature of Bacteria. International Journal of Systematic Bacteriology, 28:335336.

Staplin, F. L., J. Jansonius, AND S. A. Pocock. 1965. Evaluation of some acritarchous hystrichosphere genera. Neues Jahrbuch für Geologie und Paläontologie, Abhandlung 123:167-201.

Strother, P. K., A. H. KNOLl, AND E. S. BarghoorN. 1983. Microorganisms from the late Precambrian Narssârssuk Formation, northwestern Greenland. Palaeontology, 26:1-32.

SWETT, K., AND A. H. KNOLL. 1985. Stromatolitic bioherms and microphytolites from the Late Proterozoic Draken Conglomerate Formation, Spitsbergen. Precambrian Research, 28:327-347.

TAPPAN, H. 1980. Paleobiology of Plant Protists. Wiley, San Francisco, $1028 \mathrm{p}$.

Thuret, G. 1875. Essai de classification des Nostochinées. Annales Sciences Naturelle (Botanie), 6:372-382.

TIMofeEv, B. V. 1959. Drevejshava flora Pribaltiki i ee stratigraficheskoe znachenie [Ancient flora of the Baltic area and its stratigraphic significance]. Trudy, Vsesoyuznogo Neftyanogo Nauchno-Issledovatel'skogo Geologorazvedochnogo Instituta, Leningrad, 129:1-320.

- 1966. Mikropaleofitologichneskoe issledovanie drevnikh svit [Microphytological Investigations of Ancient Formations]. Nauka, Moscow, $145 \mathrm{p}$.

- T. N. German, AND N. S. Mikhanlova. 1976. Mikrofitofossilii dokembiya, kembriya, i ordovika [Microfossils from the Precambrian, Cambrian, and Ordovician]. Trudy, Institut Geologii i Geochronologii Dokembri, Leningrad, $106 \mathrm{p}$.

TYLER, S. A., AND E. S. BARGHOORN. 1954. Occurrence of structurally preserved plants in Precambrian rocks of the Canadian Shield. Science, 119:606-608.

VIDAL, G. 1976. Late Precambrian microfossils from the Visingsö beds in southern Sweden. Fossils and Strata, 9:1-57.

- AND A. H. KNOLL. 1983. Proterozoic plankton. Geological Society of America, Memoir 161:265-277.

- AND J. P. NYSTUEN. 1990. Stratigraphy and micropaleontology of the late Precambrian Hedmark Group, Norway. American Journal of Science, 290A:170-211.

WATERBURY, J. B., AND R. Y. Stanier. 1978. Patterns of growth and development in pleurocapsalean cyanobacteria. Microbiological Reviews, 42:2-44.

WeTtSTEIN, R. 1924. Handbuch der Systematischen Botanik, Band 1. Franz Deuticke, Leipzig, 1017 p.

Whitton, B. A., AND M. Potrs. 1982. Marine littoral, p. 515-542. In N. G. Carr and B. A. Whitton (eds.), The Biology of Cyanobacteria. Blackwell, Oxford.

Winson, C. B. 1958. The Lower Middle Hecla Hoek rocks of Ny Friesland, Spitsbergen. Geological Magazine, 94:305-327. 
1961. The Upper Middle Hecla Hoek rocks of Ny Friesland, Spitsbergen. Geological Magazine, 98:89-116.

Woese, C., AND G. FuX. 1977. Phylogenetic structure of the prokaryotic domain. Proceedings, National Academy of Science, U.S.A., 74: 5088-5090.

WrAY, J. L. 1977. Calcareous Algae. Elsevier, Amsterdam, 185 p.

YIN, L. 1987. Microbiotas of latest Precambrian sequences in China Stratigraphy and Paleontology of Systemic Boundaries in China, Precambrian-Cambrian Boundary, 1:415-494.

ZANG, W. 1989. Late Proterozoic-Early Cambrian microfossils and biostratigraphy in China and Australia. Unpubl. Ph.D. thesis, Australian National University, Canberra, Australia, 432 p.

-, AND M. R. WALTER. 1989. Latest Proterozoic plankton from the Amadeus Basin in central Australia. Nature, 337:642-645.

ZHANG, Y. 1981. Proterozoic stromatolite microfloras of the Gaoyuzhuang Formation (Early Sinian: Riphean), Hebei, China. Journal of Paleontology, 55:485-506.

ACCEPTED 27 NOVEMBER 1990

NASA Grant NAGO-893 provided $\$ 1,500$ in support of this article.

\title{
UPPER PRECAMBRIAN THROUGH LOWER CAMBRIAN OF CAPE BRETON ISLAND: FAUNAS, PALEOENVIRONMENTS, AND STRATIGRAPHIC REVISION
}

\author{
ED LANDING \\ New York State Geological Survey, \\ The State Education Department, Albany 12230
}

\begin{abstract}
Latest Precambrian through Early Cambrian tectonic history and stratigraphy are comparable in southeastern Cape Breton Island and the western Placentia-Bonavista axis, southeastern Newfoundland. The lithostratigraphic nomenclature of southeastern Newfoundland is used for this interval in Cape Breton Island. Upper Precambrian volcanic rocks of the Forchu Group (= "Giant Lake Complex," designation abandoned) are unconformably overlain by uppermost Precambrian through lowest Cambrian strata termed the "Morrison River Formation" (designation abandoned). This depositional sequence consists of three formations: 1) red beds through tidalites of the Rencontre Formation (to 279+ m; ="Kelvin Lake Formation," designation abandoned); 2 ) prodeltaic clastics of the Chapel Island Formation (to $260 \mathrm{~m}$ ); and 3) macrotidal quartzites of the Random Formation (to $71+\mathrm{m}$ ). Post-Random block faulting and $300 \mathrm{~m}$ of local erosion took place prior to onlap of the "MacCodrum Formation" (abandoned). Siliciclastic mudstones of the lower "MacCodrum" are re-assigned to the middle Lower Cambrian Bonavista Group. Sub-trilobitic faunas from the Bonavista Group include "Ladatheca" cylindrica from the West Centre Cove Formation(?) and higher diversity faunas (23 species) in the Camenella baltica Zone of the Cuslett and Fosters Point Formations. Trilobite-bearing, upper Lower Cambrian (Branchian Series) strata (Brigus Formation, =upper "MácCodrum" and overlying "Canoe Brook" Formations) unconformably overlie the Placentian Series in Cape Breton Island, southeastern Newfoundland, Shropshire, and, probably, eastern Massachusetts. Correlations based on small shelly fossils indicate an earlier appearance of trilobites in Avalon than on the South China Platform. Twenty-six species are illustrated. Halkieria fordi $\mathrm{n}$. sp., the conodont(?) "Rushtonites" asiatica $\mathrm{n}$. sp., and the zhijinitid(?) Samsanoffoclavus matthewi $\mathrm{n}$. gen. and sp. are described. Ischyrinia? sp. may be the oldest ischyrinoid rostroconch.
\end{abstract}

\section{INTRODUCTION}

$\mathrm{T}$ HE AVALON ZONE of the coastal northeastern Appalachians and southern Britain (see Rast et al., 1976; Williams and Hatcher, 1982) has considerable significance in understanding the evolutionary radiations, immigration events, and geological context of latest Precambrian and earliest Cambrian metazoans (see Landing et al., 1989). Early descriptions of the larger faunal elements (hyoliths, mollusks, and brachiopods) from the subtrilobitic and trilobite-bearing Lower Cambrian of Avalon (Holl, 1865; Shaler and Foerste, 1888; Matthew, 1889, 1899a, 1899b, 1899c; Groom, 1902; Cobbold, 1919, 1921; Cobbold and Pocock, 1934) have been complemented by the recognition of associated, diverse agglutinated, calcareous, and phosphatic small shelly fossils (Landing et al., 1980, 1989; Bengtson and Fletcher, 1983; Landing, 1984, 1988b, 1989; Brasier, 1984, 1986; Hinz, 1987). These reports and the recognition that many species of dubious validity are described from coeval Asian sequences (Landing, 1988a, 1988b; Conway Morris, 1988; Qian and Bengtson, 1989) suggest a re-interpretation of earliest Cambrian di- versity patterns. Skeletalized faunas from the siliciclastic-dominated, cooler water environments of Avalon (Landing, 1989) seem to have been only somewhat less diverse than those from warm-water, carbonate platforms of Soviet Asia and China (see Rozanov et al., 1969; Luo et al., 1982, 1984; Xing et al., 1983). In addition, uppermost Precambrian through lowest Cambrian trace fossils are more diverse in the Avalonian terrane of southeastern Newfoundland (see Crimes and Anderson, 1985; Crimes, 1987; Narbonne and Myrow, 1988) than in Asian sequences. However, trace and body fossils and their paleoenvironmental and stratigraphic distribution remain undescribed from important areas of the uppermost Precambrian and Lower Cambrian of Avalon.

This study was prompted by descriptions of the geology of southeastern Cape Breton Island (Fletcher, 1877, 1879; Matthew, 1903; Weeks, 1947, 1954; Hutchinson, 1952) that indicated the Lower Cambrian of the Mira River valley is similar to the more completely documented sequence in southeastern Newfoundland (Figure 1.1). Weeks (1954) compared the sili- 